UNIVERSIDADE DE SÃO PAULO

INSTITUTO DE PSICOLOGIA

NATALIA DE SOUZA ALBUQUERQUE

Reconhecimento de emoções em cães domésticos (Canis familiaris):

percepção de pistas faciais e auditivas na comunicação intra e interespecífica

SÃO PAULO 


\author{
UNIVERSIDADE DE SÃO PAULO \\ INSTITUTO DE PSICOLOGIA \\ DEPARTAMENTO DE PSICOLOGIA EXPERIMENTAL
}

NATALIA DE SOUZA ALBUQUERQUE

Reconhecimento de emoções em cães domésticos (Canis familiaris): percepção de pistas faciais e auditivas na comunicação intra e interespecífica

(Versão original)

Dissertação apresentada ao Instituto de Psicologia da Universidade de São Paulo como parte dos requisitos para obtenção do título de Mestre em Psicologia.

Área de concentração: Psicologia Experimental

Orientadores: Profa. Dra. Emma Otta

Prof. Dr. César Ades (in memoriam)

SÃO PAULO 
AUTORIZO A REPRODUÇÃO E DIVULGAÇÃO TOTAL OU PARCIAL DESTE TRABALHO, POR QUALQUER MEIO CONVENCIONAL OU ELETRÔNICO, PARA FINS DE ESTUDO E PESQUISA, DESDE QUE CITADA A FONTE.

Catalogação na publicação Biblioteca Dante Moreira Leite

Instituto de Psicologia da Universidade de São Paulo

Albuquerque, Natalia de Souza.

Reconhecimento de emoções em cães domésticos (Canis familiaris): percepção de pistas faciais e auditivas na comunicação intra e interespecífica / Natalia de Souza Albuquerque; orientadora Emma Otta. -- São Paulo, 2013.

$100 \mathrm{f}$.

Dissertação (Mestrado - Programa de Pós-Graduação em Psicologia. Área de Concentração: Psicologia Experimental) Instituto de Psicologia da Universidade de São Paulo.

1. Cães 2. Reconhecimento cross-modal 3. Emoções 4. Cognição 5. Comportamento social I. Título. 


\section{Reconhecimento de emoções em cães domésticos (Canis familiaris): percepção de pistas faciais e auditivas na comunicação intra e interespecífica}

Dissertação apresentada ao Instituto de Psicologia da Universidade de São Paulo como parte dos requisitos para obtenção do título de Mestre em Psicologia.

Área de concentração: Psicologia Experimental

Aprovado em: 1 1

Banca Examinadora

Prof. Dr.

Instituição: Assinatura:

Prof. Dr.

Instituição: Assinatura:

Prof. Dr.

Instituição: Assinatura: 
À minha filha, Polly, quem me fez enxergar a complexidade e a riqueza dos outros animais. Sinto sua falta a todo instante.

Aos meus pais e ao meu irmão, que foram e sempre serão a minha base e o meu porto seguro. Obrigada por tudo, amo muito vocês. 


\section{AGRADECIMENTOS}

À professora Emma Otta, que, em um momento muito turbulento, abriu os braços e me adotou. Obrigada por me dar a chance de poder continuar a pesquisa pela qual sou apaixonada, pelo apoio, pela paciência, pelas contribuições e pela oportunidade de trabalhar com alguém tão competente.

Ao professor César Ades (in memoriam), quem possibilitou a minha entrada no mundo da cognição de cães. Obrigada por todas as discussões, todos os ensinamentos e todo o entusiasmo. A sua paixão e curiosidade científica pelo Comportamento Animal continuarão sempre vivas em mim.

Ao professor Daniel Mills, que viu em mim potencial e me acolheu no Reino Unido para que ideias pudessem virar realidade. Serei eternamente grata pelas oportunidades e pelos aprendizados.

À minha mãe Targélia, ao meu pai Edison, ao meu irmão Lucas e às minhas sobrinhas Etta e Belle, que me deram a estrutura emocional, espiritual, logística, técnica e financeira para que a realização dessa pesquisa fosse possível. Obrigada por todo o carinho, por toda a paciência para ouvir meus desabafos e por todo o amor. Vocês são, absolutamente, essenciais.

Ao professor Kun Guo e à professora Anna Wilkinson, que colaboram muito com o desenvolvimento deste projeto e de quem eu aprendi muito.

À professora Marie-Odile Chelini, pelas ricas contribuições no meu Exame de Qualificação.

Ao professor Oliver Burman, no Reino Unido, à dra. Anais Racca, na França, e ao professor Antonio Souto, no Brasil, pelas valiosas contribuições metodológicas.

À CAPES, pelo suporte financeiro para a realização deste Mestrado.

Às minhas colegas de laboratório e amigas de coração, Daniela, Femanda, Angélica, Gisele, Alice, Maria, Denise e Patrícia. Obrigada por todas as palavras de carinho e de apoio.

À Fiona Williams, pelas contribuições essenciais para esta pesquisa, por ser minha segunda experimentadora e companheira de trabalho. Agradeço também por ser, juntamente à Wendy, ao Dave, Rebel e Chaos, minha família britânica, que me ajudou de incontáveis maneiras. Obrigada também ao Andy por todo o suporte técnico, que foi indispensável.

À Carine, que foi fundamental de diversas maneiras durante essa longa jornada que foi o meu Mestrado. Também ao Fernando e aos meus afilhados Meggie Lee e Whisky, que, junto à Carine, constituem minha família em São Paulo e que, desde o começo, me deram todo apoio e incentivo para continuar.

Aos meus companheiros de "Quarteto Nordestino (e meio)", Roberto, Guilherme e Rafael e, mais recentemente, Suelen. Obrigada por estarem ao meu lado e por compartilharam comigo as alegrias, as dificuldades e as conquistas desses anos de Mestrado. 
Aos meus grandes e amados amigos Analice, Mariana (Nissen), Sophia, Patrícia, Marília, Mariana (Amorim), Anete, Carla, Cristiane, Igor, Eduardo e Edson, que sempre torceram muito por mim, se fizeram presente e de quem o apoio foi essencial.

À Sônia Paiva, à Tânia Lucci e ao Gustavo Garcia por terem me acolhido quando eu precisei.

Às minhas amigas inglesas Jessica, Charlie, Lynn e Alison, que me ajudaram com o trabalho e me deram muito suporte.

À Hannah, ao Stuart, à Spook e ao Frankie, por me fazerem sentir em casa, por serem companhia diária e por serem fonte de força de motivação no tempo em que vivi no Reino Unido.

A cada um dos cães que deram sua riquíssima contribuição para esta pesquisa, que possibilitaram a descoberta de algo novo e que tornaram este trabalho possível. Agradeço também aos tutores que, com disposição, levaram seus companheiros caninos ao nosso encontro.

Finalmente, mas não menos importante, meus profundos agradecimentos à Polly. Obrigada por estar sempre comigo, seja no Brasil, na Inglaterra ou em qualquer parte do mundo, e por ser a materialização do amor, a minha inspiração e o motor da minha vida. Obrigada por me dar a força que me impulsiona e me faz querer, a cada dia, crescer e trabalhar para poder ajudar os bichos do mundo, que tanto precisam de ajuda.

A todos que, direta ou indiretamente, contribuiram com essa pesquisa e com o desenvolvimento do meu Mestrado, meus sinceros agradecimentos. 
"A humildade exprime uma das raras certezas de que estou certo: a de que ninguém é superior a ninguém."

(Paulo Freire) 


\section{RESUMO}

ALBUQUERQUE, N. S. Reconhecimento de emoções em cães domésticos (Canis familiaris): percepção de pistas faciais e auditivas na comunicação intra e interespecífica. 2013. 100 f. Dissertação (Mestrado) - Instituto de Psicologia, Universidade de São Paulo, São Paulo.

Cães domésticos (Canis familiaris) são animais sociais que apresentam uma série de habilidades cognitivas para interagir com outros cães e com pessoas. Apesar de muitos estudos com cães terem investigado o uso de pistas comunicativas, a sensibilidade a estados de atenção, a capacidade de discriminação de faces e de vocalizações e até o processamento de expressões faciais, ainda não existem evidências de que esses animais são capazes de obter e utilizar simultaneamente informações emocionais de expressões faciais e auditivas. $\mathrm{O}$ reconhecimento de estados emocionais pode ser entendido como uma característica adaptativa, uma vez que possui um papel muito importante no contexto social e pode ser crucial para o estabelecimento e manutenção de relacionamentos em longo prazo. Interessados em investigar as habilidades de leitura e compreensão de emoções, utilizamos um paradigma de preferência de olhar para testar cães de família de várias raças em sua habilidade de reconhecer emoções de maneira cross-modal. Analisamos o comportamento visual espontâneo dos sujeitos frente a dois estímulos visuais (mesmo indivíduo, expressão facial diferente) e um som (vocalização) congruente a uma das duas imagens. Utilizamos estímulos caninos e humanos, de fềmeas e machos, com valência positiva e negativa, apresentados do lado esquerdo e do lado direito, e avaliamos seus possíveis efeitos sobre o desempenho dos animais. A variável utilizada para as análises foi o índice de congruência: a proporção de tempo de olhar para a imagem congruente em relação ao tempo total de olhar para as telas. Os cães demonstraram ser capazes de associar informações das faces (fotografias) e das vocalizações (playbacks) e integrá-las em uma única representação mental, independente da espécie, do sexo, da valência e do lado de apresentação do estímulo. O único efeito que encontramos foi o de espécie: apesar dos sujeitos apresentarem a habilidade de reconhecimento tanto para estímulos caninos quanto para humanos, o fizeram de maneira mais robusta para coespecíficos. Isto pode sugerir que a habilidade de reconhecer emoções de maneira cross-modal tenha surgido inicialmente para a comunicação intraespecífica, mas, tendo facilitado a convivência com seres humanos, se desenvolveu para tornar a comunicação interespecífica mais eficiente. O reconhecimento cross-modal pode ser entendido como um reconhecimento verdadeiro e sugere um nível de processamento cognitivo mais alto e mais complexo. Dessa maneira, esta pesquisa traz as primeiras evidências de que cães domésticos são capazes de compreender (perceber e extrair informações relevantes de) as emoções e não apenas discriminá-las. As interações entre um indivíduo e o mundo são multidimensionais e perceber emoções de outros cães e de pessoas pode ser altamente funcional.

Palavras-chave: cães; reconhecimento cross-modal; emoções; cognição; comportamento social. 


\begin{abstract}
ALBUQUERQUE, N. S. Emotion recognition in domestic dogs (Canis familiaris): perception of facial and auditory cues in intra and interspecific communication. 2013. 100 f. Dissertação (Mestrado) - Instituto de Psicologia, Universidade de São Paulo, São Paulo.
\end{abstract}

Domestic dogs (Canis familiaris) are social animals that show a series of cognitive abilities to interact with other dogs and people. Although many studies have investigated the use of communicative cues, the sensitivity to attentional states, the capacity of discriminating faces and vocalizations and even the processing involved in facial expressions exploration, there are no evidences that these animals are capable of obtaining and using emotional information from facial and auditory expressions. The recognition of emotional states may be understood as an adaptive feature, since it plays a very important role in social context and might be crucial to the establishment and maintenance of long term relationship. Interested in investigating the abilities of reading and understanding emotions, we used a preferential looking paradigm to test family dogs of various breeds for their ability to cross-modally recognize emotions. We analysed the spontaneous looking behaviour of subjects when facing two visual stimuli (same individual, different facial expression) and hearing a sound (vocalization) which was congruent to one of the images. We used dogs and humans, females and males, positive valence and negative valence and left-presented and right-presented stimuli to assess their possible effects on the animals' performance. The variable used for the analysis was congruence index: the proportion of time looking at the congruent images over the total looking time to the screens. Dogs demonstrated being capable of associating information from faces (photographs) and vocalizations (playbacks) and integrating them in a single mental representation, independent of species, sex, valence or side of stimulus presentation. The only effect we found was of species: although subjects had shown the ability to recognize both canine and human stimuli, they did it in a more robust way towards conspecifics. This may suggest that the ability to cross-modally recognize emotions has initially appeared for intraspecific communication but, having facilitated dog-human interactions, has developed to make the interspecific communication more efficient. Crossmodal recognition can be understood as true recognition and it suggests a higher and more complex level of cognitive processing. Therefore, this research brings the first evidences that domestic dogs are able to understand (perceive and extract relevant information from) emotions and not only discriminate them. The interactions between an individual and the world are multidimensional and reading other dogs and human emotions may be highly functional.

Keywords: dogs; cross-modal recognition; emotions; cognition; social behaviour. 


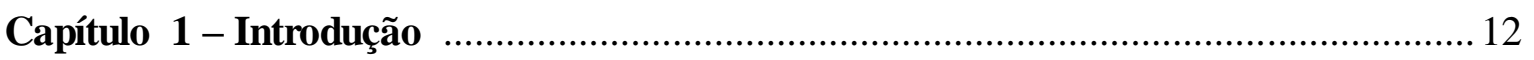

1.1.Cães domésticos (Canis familiaris) ……………………………………....... 13

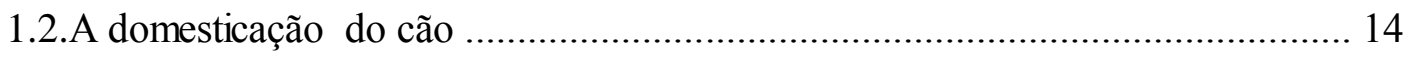

1.3.O cão como sujeito de estudo ……………………………………………...... 17

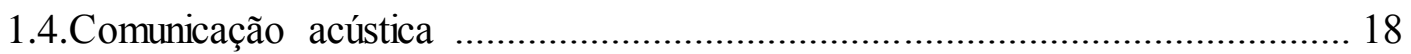

1.5.Comunicação visual ...................................................................................... 21

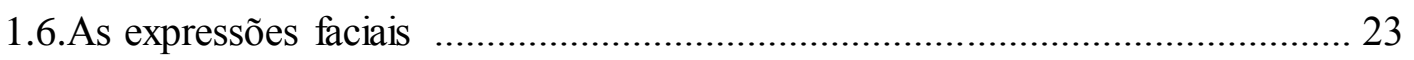

1.7.Reconhecimento de emoções ......................................................................... 24

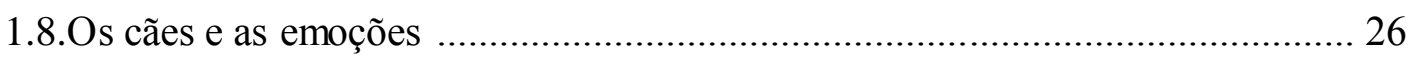

1.9.Os cães, as emoções e as expressões faciais ………………………………..... 28

1.10.Os cães, as emoções e as vocalizações ……………………………………... 33

1.11.Reconhecimento cross-modal .................................................................. 35

1.12.Reconhecimento cross-modal em não humanos ……………………………. 38

1.13. Os cães e o reconhecimento cross-modal ................................................... 39

1.14.0 estudo do reconhecimento cross-modal ..................................................... 41

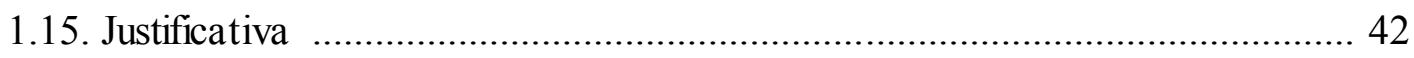

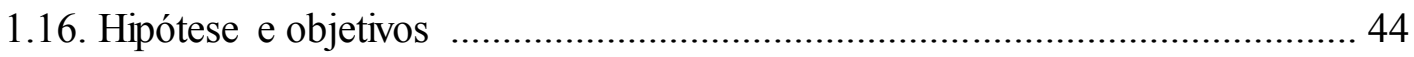

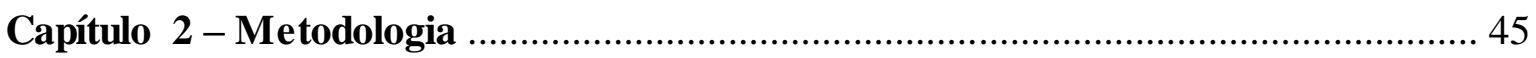

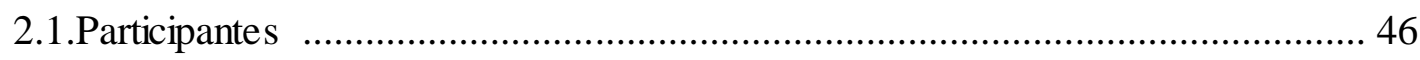

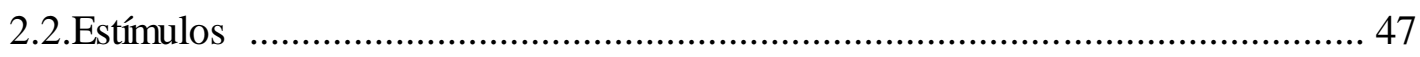

2.3.Desenho experimental ................................................................................. 50

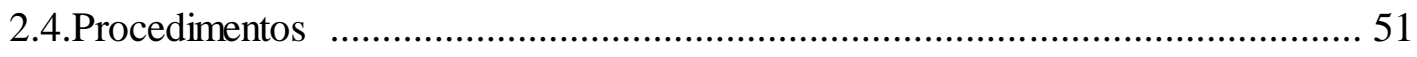

2.5.Codificação e análises comportamentais ........................................................ 57

2.6.Análises estatísticas ...................................................................................... 58

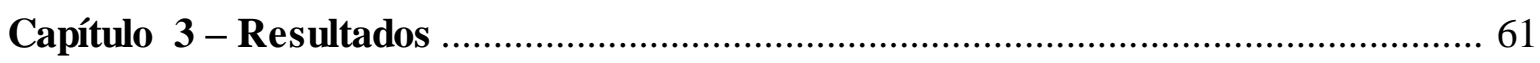

3.1.Congruência: a ocorrência do matching …………………………………….... 62

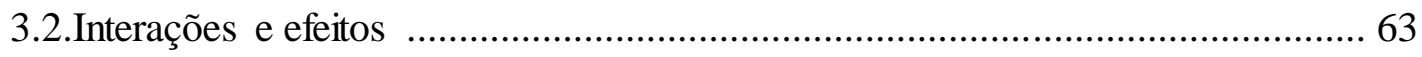




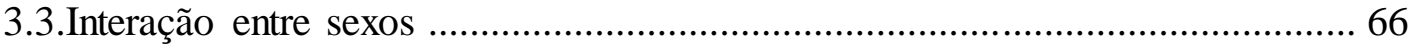

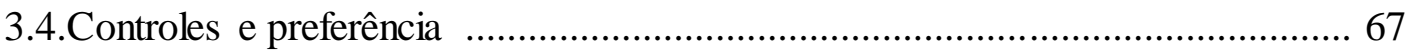

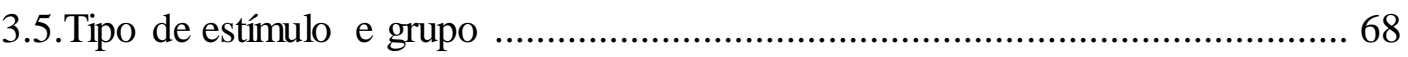

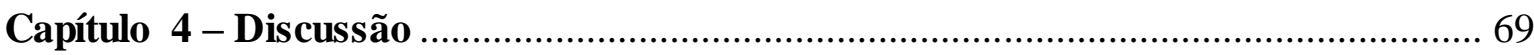

4.1.Reconhecimento cross-modal de emoções ..................................................... 71

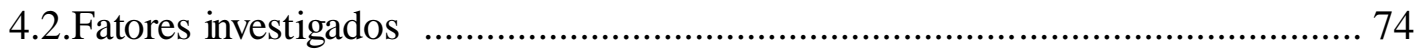

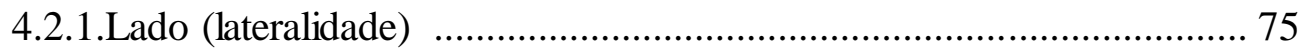

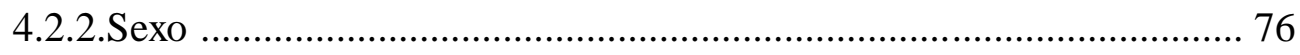

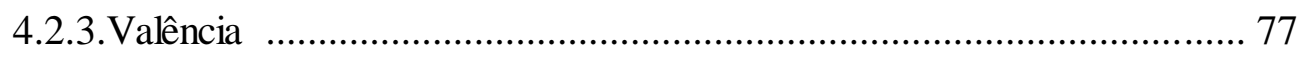

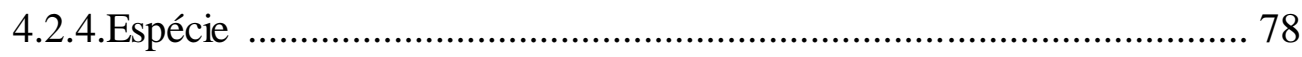

4.3.Comunicação intraespecífica e interespecífica ............................................... 80

4.4.Percepção e reconhecimento de emoções ....................................................... 82

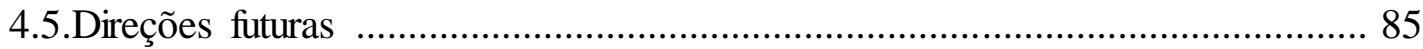

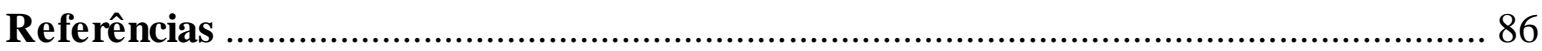

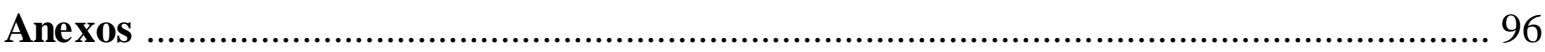

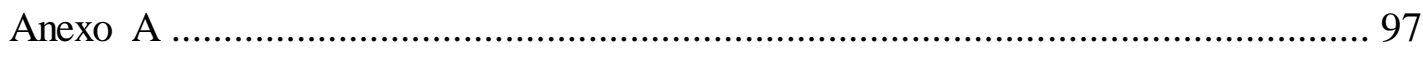

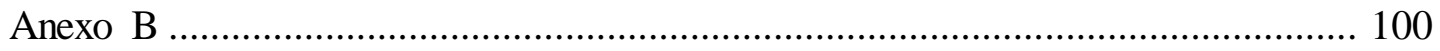


Capítulo 1 - Introdução 


\section{Introdução}

\subsection{Cães domésticos (Canis familiaris)}

Cães pertencem à família dos canídeos, que é um grupo de mamíferos carnívoros dividido em 38 espécies. Entre elas, apenas o Canis familiaris (cães domésticos) foi realmente domesticado. De acordo com Galibert et al. (2011), a domesticação é um longo processo, em que os seres humanos são capazes de modificar vários traços da fisiologia $\mathrm{e}$ do comportamento de outros seres através das gerações.

Em 1978, Davis e Valla encontraram o primeiro fóssil de cão: um esqueleto de um filhote em íntima associação com um ser humano, datado de 12.000 anos. De acordo com Savalli e Ades (2011), é possível que o processo de domesticação tenha tido início quando os primeiros lobos (ou ancestrais comuns aos lobos) se aproximaram das aldeias ou agrupamentos humanos e desde que começaram a ser aceitos e a ocuparem posições de interesse humano (i.e. guarda); em parte espontâneo e em parte dirigido por práticas de seleção e acasalamento intencionais.

A domesticação dos cães provavelmente começou durante o período paleolítico (35000 AC), muito antes da domesticação de qualquer outro animal ou planta, tendo o fóssil de cão (com marcas claras de diferenciação dos lobos) mais antigo sido datado em 31.700 anos (Galibert et al., 2011). De acordo com Galibert et al. (2011), esse processo mais antigo, talvez inconsciente, é chamado de proto-domesticação e se distingue da domesticação real que está datada em 14000 AC. Análises de DNA genômico têm mostrado, recentemente, que a domesticação começou no leste da Ásia e se expandiu para outras regiões (Savolainen et al., 2002).

No entanto, ainda existem controvérsias em relação ao surgimento dos cães. Alguns estudos genéticos sugerem que os cães devem ter divergido dos lobos em diferentes épocas, começando há 135.000 anos (Vilà et al., 1997). Isto é, quando a estrutura morfológica de certos grupos de "lobos" começou a mudar para se assemelharem ao cão doméstico atual.

Segundo Reid (2009), humanos podem ter fornecido aos antigos canídeos uma rica fonte de alimento, na forma de restos de comida e dejetos fecais, e esses animais foram tolerados, possivelmente até encorajados, pelos humanos por consumir esse lixo biológico. Cães se tornaram dependentes dos humanos para sua própria sobrevivência, enquanto para os 
humanos os cães podem ter servido primeiramente pela sua função "higiênica".

Estudos de comportamento, comunicação, morfologia e biologia molecular mostram que o lobo cinza (Canis lupus) é o parente mais próximo, dividindo com o cão doméstico 98\% de DNA mitocondrial (Vila et al., 1997). Hoje em dia, são mais de 400 raças de cães espalhadas por todo o mundo (Galibert et al. 2011; Udell \& Wynne, 2008), além dos cães de raça misturada e sem raça definida (vira-latas). A seleção artificial desses animais para as várias raças levou à criação de animais melhor adaptados para diferentes propósitos humanos: guarda, pastoreio, caça e companhia.

A presença dos cães é universal; estavam e estão presentes em todas as culturas e ocupam uma posição especial na vida humana (Gabilert et al, 2011). Pessoas inclusive se referem a seus cães como membros da família. Cães e seres humanos têm compartilhado essencialmente o mesmo nicho ecológico há, pelo menos, 14.000 anos (Galibert et al., 2011) e, possivelmente, há até 135.000 (Vilà et al., 1997). Durante este período, há consenso de que o cão tenha sido selecionado com a facilitação de sua convivência com o ser humano e em aspectos cognitivos apropriados para a realização de diferentes tarefas (Savalli et al., 2009; Hare et al., 2002).

Acredita-se que o cão esteja especialmente preparado para perceber e interpretar sinais comunicativos do ser humano (Pongrácz et al. 2001, Topál et al., 2006) e para comunicar-se com ele usando seu repertório natural de comportamentos (Ades et al., 2000). Alguns argumentam que cães e pessoas são mais do que espécies simpátricas, que essa associação tenha sido mutuamente benéfica e que espécies distantes (filogeneticamente) podem mostrar evidências de uma possível evolução convergente por terem enfrentado os mesmos desafios ecológicos (Reid, 2009).

\subsection{A domesticação do cão}

Domesticação pode ser entendida como o caminho evolutivo através dos quais animais se tornam adaptados ao ambiente humano - mudanças morfológicas e comportamentais estão envolvidas. Nesse sentido, tanto processos naturais quanto artificiais de seleção estão presentes e agem sobre os indivíduos. Apesar do aparecimento dos cães ser um evento bastante antigo, o processo evolutivo pelo qual passaram (de seus ancestrais até hoje) ainda continua sob debate. 
Um trabalho importante (um dos poucos estudos de longa duração) começou na década de 1950, quando o geneticista russo Belyaev tentou remontar o processo de domesticação com uma população de raposas. Por acreditar que apenas seria possível pessoas e outros animais ocupando o mesmo grupo social se seres humanos houvessem selecionado, mesmo que inconscientemente, esses animais pela redução de comportamentos agressivos, selecionou raposas pelos seus traços comportamentais para entender melhor a evolução desse processo. Cruzou os indivíduos que demonstravam menos sinais de agressividade direcionados às pessoas, tomando o cuidado de evitar endogamia e, consequentemente, a homozigose. Após mais de 40 gerações, as raposas selecionadas mostraram diversos traços comportamentais semelhantes aos cães: comportamentos afiliativos, balançar de cauda, vocalizações direcionadas a pessoas, entre outros. Essas modificações comportamentais aconteceram paralelamente a mudanças fisiológicas, como alteração do ciclo reprodutivo e aumento da taxa reprodutiva, mudanças morfológicas, como o aparecimento de orelhas caídas e cauda curvada (Belyaev, 1979). A pelagem se alterou aparecendo manchas claras. É interessante notar que este é um padrão que pode ser notado em outros animais domésticos.

Belyaev investigou o papel do desenvolvimento na evolução de animais domésticos. Ele acreditava que os principais processos afetando a ontogenia e conduzindo a domesticação ocorreram no início, num estágio inicial de estabelecimento de relações entre seres humanos e “cães". Independente do cenário neste período inicial, a domesticação pode ter sido determinada pela seleção de determinados comportamentos e capacidade de se adaptar e coexistir com pessoas. Principalmente no período inicial da domesticação dos cães, a seleção natural preservou seu papel de força dominante, sendo o humano apenas um fator que mudou, inconscientemente, a direção desse processo: animais menos agressivos apresentavam vantagens nesse novo ambiente social interespecífico. Foi apenas gradualmente que a seleção natural perdeu espaço para a seleção artificial (Trut et al., 2004).

De acordo com Trut et al. (2004), Belyaev acreditava que era possível reproduzir as consequências da seleção natural no estágio inicial de domesticação e que isso poderia ser feito em um período curto de tempo, uma vez que uma pressão seletiva muito forte fosse aplicada. O objetivo central de seu estudo foi de "replicar" o que entendia como a chave da domesticação inicial: seleção comportamental. Os resultados do estudo de domesticação de raposas apontaram para possíveis mecanismos de transformação do comportamento que agiram sobre os ancestrais dos cães em direção à domesticação. Mostraram, também, que uma pressão de seleção extrema é um fator de ação rápida sobre traços comportamentais e pode resultar, inclusive, em modificações na morfologia e na fisiologia dos animais. Belyaev 
sugeriu que várias características do caminho evolutivo pelo qual o cão doméstico passou podem ser reproduzidos em gerações - dependendo da força da pressão - e reforçou a ideia de que os "cães" devem ter sido selecionados, pelo menos inicialmente, pelos seus comportamentos menos agressivos.

Hare et al. (2012) apontam para dois estágios de seleção propostos para cães domésticos. O primeiro envolve uma seleção natural, ou "auto-domesticação", quando não houve qualquer processamento intencional pelos humanos. Neste processo, "lobos" menos agressivos e que mostravam menos medo tiveram uma vantagem seletiva, uma vez que eram capazes de se aproximar de grupamentos humanos e, consequentemente, explorar novas oportunidades ecológicas. Depois que esses proto-cães começaram a se comportar de maneira social apropriada em direção a seres humanos, o segundo estágio do processo de evolução desses animais começou: seleção intencional de animais por determinadas características.

A redução da agressividade e o aumento da tolerância social são analisados por Ribeiro, Bussab e Otta (2009) como parte de um conjunto de alterações fisiológicas, morfológicas, cognitivas e comportamentais na evolução humana. Hare et al. (2012) sugeriram que a seleção contra agressividade em algumas espécies selvagens pode operar de maneira similar ao que ocorreu com animais domésticos. Apontam, então, os bonobos como prováveis candidatos de terem passado por esse processo de auto-domesticação autores consideram o estágio inicial da evolução do cão a partir do ancestral comum com o lobo é um modelo importante para o estudo das diferenças entre os bonobos, animais que demonstram alta tolerância social, e sua espécie irmã, os chimpanzés, que apresentam formas severas de agressividade.

O principal traço que une as espécies domésticas é a redução da expressão de diversas formas de comportamentos de agressão, incluindo intraespecífica, interespecífica, ofensiva e defensiva. Lobos e cães ferais podem ser um bom modelo para estudar diferenças entre animais domesticados e selvagens, tendo sido um dos pares de animais mais bem estudados. Bonobos mostram menos sinais de agressividade - além de diferenças morfológicas que podem ser entendidas como análogas a diferenças entre animais domesticados e seus ancestrais - em comparação a chimpanzés, possivelmente por diferenças nos esquemas de competição alimentar nas duas espécies. Dentro dessa perspectiva, a hipótese de autodomesticação pode fornecer explicações plausíveis sobre a origem das muitas diferenças entre bonobos e chimpanzés que, possivelmente, apareceram como subprodutos incidentais. É possível, então, que o processo de domesticação inicial - fruto de seleção natural - pelo qual os cães provavelmente passaram seja uma característica bastante difundida na evolução de 
mamíferos.

\subsection{O cão como sujeito de estudo}

A grande maioria dos estudos sobre a evolução da cognição social partiu dos estudos com crianças e primatas não humanos (Zuberbühler e Byrne, 2006; Udell \& Wynne, 2008). O interesse era centrado nos grandes primatas e a preocupação era encontrar a origem dos mecanismos cognitivos e de comunicação típicos do ser humano. Desde Darwin, a procura por uma cognição social parecida com a do ser humano esteve focada particularmente nos chimpanzés.

A preferência pela realização de pesquisas com primatas pode ser devida ao interesse de trabalhar com parentes filogeneticamente próximos. No entanto, não há razão para assumir que os mesmos princípios e pressões evolutivas não tenham agido sobre outros grupos de animais sociais e que algumas espécies não primatas possuam inteligência social comparável. A literatura atual é consistente com a ideia de que a seleção natural não precisa de um cérebro primata para endossar uma inteligência social (Zuberbühler e Byrne, 2006).

Os primatas, por muito tempo, foram considerados os candidatos mais favoráveis a exibir formas salientes de habilidades cognitivas similares às dos humanos (Horowitz, 2009). Por exemplo, primatas humanos e não humanos eram o foco principal nos estudos de percepção do olhar e habilidades relacionadas, apesar de os primatas não serem os únicos a viverem em sistemas sociais sofisticados que se baseiam em sinais visuais (Virányi et al., 2004). No entanto, existe um crescente embasamento científico mostrando que animais de diferentes espécies são sensíveis à orientação visual de seus coespecíficos e que o cão doméstico pode ser um sujeito promissor na investigação da emergência de habilidades finas de leitura da atenção, por exemplo (Miklósi et al., 2004; Virányi et al., 2004).

Os últimos 20 anos presenciaram o ressurgimento da pesquisa sobre o comportamento dos cães domésticos (Udell \& Wynne, 2008). Como ressalta Miklósi (2007), etólogos geralmente ignoravam cães por não serem animais "selvagens". No final da década de 90, o interesse no comportamento dos cães cresceu abruptamente. Os cães são filogeneticamente distantes dos humanos, mas são animais altamente sociais, além de possuírem uma característica que lhes é única: vivem em contato diário e intenso com pessoas e geralmente respondem apropriadamente a muitos de seus comportamentos. Cães domésticos, apesar de 
distantes evolutivamente, têm uma longa associação com a sociedade humana (Galibert et al., 2011; Horowitz, 2009; Vilà et al. 1997). Como resultado, tem sido especulado que cães são adaptados de forma não usual a interpretar e produzir sinais salientes para humanos.

Miklósi et al. (2004) afirmam que os cães são excelentes modelos para o estudo da evolução social humana porque suas habilidades de compreensão social são um exemplo de evolução convergente: os cães servem como um análogo funcional dos seres humanos. Além disso, são particularmente interessantes no estudo da cognição social, uma vez que são espécies sociais e demonstram sensibilidade a pistas comunicativas (Williams et al., 2011).

Pesquisas recentes têm demonstrado que cães domésticos têm habilidades sociais que superam aquelas de outros animais de várias maneiras. Existem evidências de que essas habilidades são, inclusive, mais fortes do que em outros canídeos (Hare et al., 2002; Miklósi et al., 2003) e em espécies geneticamente relacionadas ao ser humano mas que não coexistem com ele, como alguns primatas (Elgier et al., 2009).

$\mathrm{O}$ cão doméstico ficou negligenciado por muito tempo no campo da Ciência, tendo se tornado um sujeito interessante de estudo recentemente. No entanto, o cão começou a ser visto como um bom modelo para investigações sobre o comportamento pela sua relação particular com os seres humanos, tendo o foco das pesquisas girado em torno dessas interações. Por esse motivo, por muitas vezes ficam esquecidas as interações entre membros da mesma espécie (cão-cão) e os fatores relacionados a elas. Marc Bekoff é o exemplo de um etólogo bastante interessado pelas interações intraespecíficas em mamíferos (e.g. Bekoff, 1977, 1995), tendo realizado importantes estudos sobre comportamento de brincadeira em canídeos como cães, coiotes e lobos (i.e. Bekoff, 1974). No entanto, ainda existe uma carência de investigações sobre comportamentos intraespecíficos e sobre os mecanismos envolvidos na percepção de emoções entre cães. Faz-se, então, necessário que estudos nessa área, numa perspectiva etológica, sejam realizados em conjunto com estudos interespecíficos.

\subsection{Comunicação acústica}

Sinais acústicos de animais podem fornecer informação sobre o sinalizador, como peso corpóreo, estado emocional, estado motivacional, identidade e contexto comunicativo (e.g. Gerhardt, 1992). Vários estudos já demonstraram que vocalizações têm características que são específicas do contexto e que podem ser influenciadas pela motivação ou emoções de 
um indivíduo.

Cães domésticos, assim como os seus parentes mais próximos (lobos, coiotes e raposas), têm um repertório vocal rico (Yeon, 2007) e esses diferentes sinais sonoros são usados numa variedade de contextos (Pongrácz et al., 2010).

Feddersen-Petersen (2000) apontaram para diferentes categorias emocionais/funcionais dos latidos de cães, como brincadeira, exploração, cuidado, contato social, comportamentos agressivos (tanto defensivo quanto ofensivo), entre outros. "Interação" (desde brincadeira agressiva entre filhotes até comportamento afiliativos entre adultos) parece ser a categoria de contexto social mais comum, com mais de metade das ocorrências registradas. Em paralelo à vida social dos cães, o componente comunicativo de suas vocalizações parece estar em constante desenvolvimento. A grande variação das estruturas fisicas dos latidos faz com que esses sons possam ser usados de maneira significativa em diferentes contextos.

Yin e Cowan (2004) observaram que latidos de cães domésticos podem ser divididos em subtipos, baseando-se no contexto, até mesmo para o mesmo indivíduo. Além disso, cães podem ser identificados pelos seus latidos, inclusive quando não há conhecimento sobre a situação na qual o sinal foi emitido. Os animais são capazes de perceber diferenças de significado entre variados contextos e de ajustar seu comportamento de acordo com cada situação. Três classes principais de latidos podem ser diferenciadas: perturbação, isolamento e brincadeira. No entanto, é possível que existam outras classes (ou subclasses).

Molnár et al. (2009), usando um paradigma de habituação-discriminação, encontraram que cães são capazes de discriminar latidos gravados em diferentes situações, mesmo quando eram emitidos pelo mesmo animal. Além disso, descobriram que os cães podem discriminar indivíduos através de vocalizações, o que sugere que esses sinais são realmente contextoespecíficos e que apresentam diferenças acústicas individuais. Estes resultados apontam para a ideia de que os latidos podem ter um papel comunicativo complexo, tanto na relação cãocão quando na relação cão-ser humano.

Com relação a outros tipos de vocalizações emitidas pelos cães domésticos, Faragó e colaboradores (2010b) demonstraram que rosnados também são contexto-específicos, sendo produzidos principalmente em situações ameaçadoras (defensivas ou ofensivas) e em interações sociais positivas como a brincadeira. Os pesquisadores observaram que o conteúdo dessas vocalizações também é percebido pelos cães: quando ouviram um rosnado de guarda passaram menos tempo em contato com um alimento disponível em relação a situações com playback de rosnados de brincadeira e de rosnados ameaçadores emitidos por estranhos. Um 
achado interessante e um tanto controverso foi que os cães se aproximaram mais da comida quando o rosnado ameaçador estranho estava tocando. Isto pode sugerir que os sujeitos não estavam respondendo puramente ao conteúdo emocional das vocalizações, mas à informação sobre o contexto social. Estes resultados corroboram outros estudos no sentido de dar evidências de que os cães domésticos são capazes de discriminar vocalizações de seus coespecíficos. Por outro lado, a habilidade de reconhecer informação emocional nesses sinais acústicos ainda continua incerta.

Enquanto os estudos sobre a capacidade de discriminação de vocalizações de coespecíficos é bastante recente, já na década de 30 Buytendijk e Fischel relataram a habilidade de cães de discriminar características da fala humana. Os pesquisadores se basearam no treinamento de um cão para desempenhar ações específicas de forma consistente ao ouvir um comando. O treino foi seguido de situações experimentais, nas quais os fonemas de palavras eram mudados sistematicamente. Eles encontraram que o começo da palavra tem mais significado para os cães, uma vez que os sujeitos responderam ao comando mais facilmente do que em outras condições - pode ser o reflexo do comportamento canino ter se iniciado logo no começo da emissão da palavra. (Miklósi, 2007).

Fukuzawa et al. (2005) treinaram seis cães domésticos a "sentar" e "vir" em resposta a comandos gravados. Os fonemas destes comandos foram manipulados e a resposta comportamento dos sujeitos a esses sinais modificados foi registrada. Houve variação comportamental em todas as situações, tendo sido mais forte para o comando de sentar, o que sugere que esses animais extraem algum tipo de conteúdo desses sinais, não apenas reconhecendo-os como sons fisicos.

A comunicação em cães ocorre quando as ações de um cão fornecem sinais que modificam de alguma forma o comportamento de um outro cão ou ser humano. Em geral, os sinais utilizados por esses animais em interações com coespecíficos são também utilizados para se comunicar com pessoas. (Yeon, 2007)

Pongrácz et al. (2006) encontraram que pessoas são capazes de categorizar os latidos de cães de forma acurada, podendo inferir o contexto e o conteúdo emocional, mesmo sem ter conhecimento do situação original. Os pesquisadores pediram para pessoas descreverem diversas sequências de latidos com base no estado emocional do cão emissor do sinal. Descobriram que pessoas com diferentes níveis de experiência com cães conseguiram descrever o conteúdo emocional dos latidos e o fizeram de maneira muito semelhante independentemente de experiência com a raça do cão.

Comportamentos não verbais como vocalizações, expressões faciais, olhar, gestos 
corporais, cheiros e toque provêm informações básicas sobre outros indivíduos e o ambiente. Existem muitas dicas sensoriais para a avaliação da emoção dos indivíduos e o tipo de informação que é importante pode variar. Para seres humanos, por exemplo, as expressões faciais (dicas visuais extremamente complicadas) desempenham um papel vital (Nagasawa et al., 2011).

Estados emocionais são caracterizados por mudanças tanto na face quanto na voz e esta redundância de informações pode contribuir para um percepto mais robusto quando um ou outro canal sensorial transmite informações incompletas (Campanella \& Belin, 2007). As expressões faciais, por exemplo, fornecem um canal primário para transmissão de informação afetiva (Parr, 2001) e são uma forma muito importante de expressar emoções e reconhecer e responder apropriadamente a elas, desempenhando um papel crucial para comunicação social (Bruce \& Young, 1986). Movimentos faciais que envolvem a região da boca podem afetar as propriedades ressonantes do trato vocal de maneira a influenciar a produção de vocalizações (Campanella \& Belin, 2007).

\subsection{Comunicação vis ual}

A habilidade de obter informações de faces e de responder apropriadamente a elas pode carregar vantagens adaptativas tanto para interações intraespecíficas como também para interespecíficas, especialmente quando o conteúdo emocional dessas faces tem valor ecológico e significado comportamental para o observador (Guo et al., 2009). O mesmo pode ser considerado para vocalizações e outros tipos de estímulos.

A comunicação através de sinais visuais é uma característica crucial na relação entre cães e entre o cão e o ser humano. Cães de trabalho, como cães de caça e de pastoreio, por exemplo, provavelmente foram selecionados pelo seu entendimento de sinais comunicativos humanos, incluindo sinais visuais (Schwab \& Huber, 2006).

Em uma rápida inspeção inicial, as faces fornecem informações sobre o sexo, idade, identidade individual e emoção (Parr et al., 2000), além de reações e intenções. Por isso, a habilidade de reconhecer dicas faciais e responder apropriadamente a elas desempenha um papel importante na comunicação social (Bruce \& Young, 1986).

Já é sabido que seres humanos são muito eficientes em diferenciar e reconhecer faces, tendo sido sugerido, inclusive, um mecanismo cognitivo e neural específico para o 
processamento das mesmas. Mas a habilidade de diferenciar indivíduos com base nas dicas faciais não é restrita a humanos: vários animais, principalmente mamíferos, podem discriminar as faces de seus coespecíficos (Bruce \& Young, 1986).

A habilidade de usar as informações que estão contidas em uma face e de responder discriminativamente a elas tem desempenhando um papel crucial na comunicação social de primatas e outras espécies de animais sociais, principalmente entre os mamíferos (Parr et al., 2000; Hare \& Tomasello, 2005). Fox (1970) argumentava que lobos, coiotes e cães domésticos diferiam das raposas porque apresentavam uma gama mais ampla de combinações simultâneas de várias expressões faciais - o que podia indicar um aumento dos sinais visuais nas espécies mais sociais.

A comunicação facial desempenha um papel crucial na cognição social de humanos e de várias espécies de animais não humanos (Guo et al.., 2009). Na evolução dos primatas, por exemplo, houve uma tendência ao aumento do tamanho e da complexidade dos grupos sociais, quando os indivíduos passaram a usar mais pistas visuais, como sinais faciais, para a comunicação (Parr et al., 2000). Gothard et al. (2003) acreditam que uma diferenciação e avaliação rápida da intensidade de expressões faciais agonísticas ou afiliativas é um imperativo de sobrevivência para muitos animais.

Indivíduos não respondem simplesmente a estímulos sociais específicos, mas interagem com um campo social complexo que está constantemente mudando e é dependente do comportamento e da motivação dos outros (Parr et al., 2000). Reconhecer emoções faciais permite que detectemos o estado ou a reação emocional do outro, o que pode proporcionar dicas sobre como responder e se comportar em situações sociais. De acordo com Nagasawa et al. (2011), identificar o estado emocional dos outros é de extrema importância para animais sociais (na tomada de decisão sobre comportamentos futuros) e, por isso, pode afetar a sobrevivência dos indivíduos, tornando-se uma característica adaptativa.

Em geral, aceita-se a ideia de que a emergência evolutiva da cognição social está intimamente relacionada ao campo social, que geralmente apresenta muitas demandas adaptativas complexas, como o reconhecimento de coespecíficos, o desenvolvimento de estratégias para manutenção do grupo social, a elaboração de comportamentos que facilitem a coordenação de ações (de Haan \& Nelson, 1999). Parr et al. (2000) argumentam que o reconhecimento facial desempenha uma adaptação social e constitui uma importante característica para aqueles que exibem uma grande quantidade de comportamentos cooperativos.

Cães são animais muito sociais e partilham vários métodos de comunicação visual 
com os lobos, incluindo posturas e expressões faciais. Têm uma longa história de domesticação - adaptação ao ambiente humano, estando expostos a seres humanos há milhares de anos, e vivem em interação diária com os seres humanos, o que torna a experiência bastante intensa.

\subsection{As expressões faciais}

De acordo com Parr et al. (2000), as faces são uma das classes de estímulos mais importantes e salientes envolvidas na comunicação social. Expressões faciais são modificações faciais em resposta ao estado emocional interno de um animal, suas intenções ou sinais de comunicação social. Feddersen-Petersen (2001), por exemplo, apontam para algumas regiões faciais que desempenham papel importante na expressão da agressividade em cães: região boca, lábios, região do focinho, testa, olhos e orelhas.

A análise das expressões faciais tem sido um tópico de pesquisa ativo para os cientistas do comportamento desde o trabalho de Darwin "A expressão das emoções nos homens e nos animais". Muitos aspectos da cognição e do comportamento humano, por exemplo, são melhor explicados com referência aos milhões de anos de evolução das interações sociais (Humphrey, 1976). Nesse contexto, a inteligência social não vai se refletir simplesmente no cérebro, mas em todas as adaptações que possibilitam interações bem sucedidas nos grupos sociais (Schmidt \& Cohn, 2001).

A comunicação facial desempenha um papel crucial na cognição social de humanos e de várias espécies de animais não humanos (Guo et al., 2009). De acordo com Schmidt e Cohn (2001), a capacidade de ler emoções pode ser uma ferramenta social muito importante, uma vez que pode trazer consequências positivas mútuas em termos de aptidão, tanto para o sinalizador quanto para o receptor. A face é um sinal visível das intenções e motivações de um indivíduo para o outro e a expressão facial é uma variável crítica nas interações sociais.

A face é um sinal visível das intenções e motivações de um indivíduo para o outro e a expressão facial é uma variável crítica nas interações sociais (Schmidt \& Cohn, 2001). Para seres humanos, as expressões sociais são interpretadas como uma característica universal, com expressões básicas representadas em todas e mais diversas populações (Brown, 1990; Ekman, 1972).

A qualidade das ações faciais varia em função dos músculos faciais. Existem variações 
individuais na estrutura e diferenciação dos músculos faciais, no entanto, se a ação da face é a mesma, mesmo que haja variações na estrutura muscular de base, as expressões faciais resultantes não serão significativamente diferentes. $O$ conceito de universalidade das expressões faciais básicas possibilitou o entendimento das expressões faciais humanas como fenótipos comportamentais evoluídos (Schmidt \& Cohn, 2001). Expressões faciais são sociais, de modo que são produzidas com grande frequência e intensidade em situações sociais e podem ser diretamente relacionadas a consequências interativas (Fridlund, 1997). Se as expressões faciais (incluindo displays de emoção) são adaptações sociais, então elas são sinais produzidos primariamente com um propósito social.

Existem evidências que sugerem que as expressões faciais funcionam para aumentar a cooperação e a afiliação durante as interações. As consequências positivas na aptidão incluem a promoção de aceitação social e a moderação de efeitos de ações sociais negativas. Essas consequências são significativas pelo menos quanto a algumas variáveis sociais. $O$ sorriso pode trazer consequências positivas e é possível que facilitem na construção de relações recíprocas (Schmidt \& Cohn, 2001). De acordo com Schmidt e Cohn (2001), uma única expressão facial não pode trazer grandes beneficios diretos ou custos diretos. É, no entanto, a sinalização repetida das intenções e das emoções que provavelmente contribui de forma importante para o fitness de um sujeito.

As expressões faciais, no entanto, ocorrem em um grande número de contextos sociais, alguns não cooperativos. A complexa relação entre contexto social e interesses compartilhados ou conflitantes sugere que expressões faciais podem ter funções múltiplas (Schmidt \& Cohn, 2001).

\subsection{Reconhecimento de emoções}

Darwin (1872) estabeleceu as bases do estudo sobre a expressão e a percepção das emoções nos animais humanos e não humanos. Ao longo dos anos, especialmente nas últimas décadas, o interesse por esse tema de pesquisa tem aumentado e muitos pesquisadores têm colaborado com o desenvolvimento e aplicação de metodologias eficazes para a investigação das capacidades de percepção e interpretação de informações emocionais.

Emoção pode ser entendida como um estado biológico que envolve uma série de componentes: percepção, expressão, experiência, processos fisiológicos, entre outros. A 
percepção do estado emocional do outro acontece de maneira multidimensional, uma vez que a emoção pode ser expressa através de vários tipos de comportamentos. Estudos importantes sobre percepção de emoções foram realizados com cães domésticos e os resultados apontam para a existência de sistemas complexos de processamento de informações emocionais, inclusive no que se diz respeito à relação entre cão e ser humano.

O reconhecimento das emoções dos indivíduos tem um papel importante na vida social, especialmente em sistemas sociais complexos, já que permite a avaliação do estado emocional de diferentes animais em diferentes situações, podendo afetar as relações estabelecidas entres eles. Pode ser essencial para o estabelecimento e manutenção de laços sociais e relacionamentos (i.e. competição, posições hierárquicas, cooperação).

A avaliação dos mecanismos envolvidos no reconhecimento de indivíduos e de seus estados psicológicos pode fornecer ideia sobre a estrutura social e as relações entre indivíduos em um grupo. As faces têm características morfológicas distintivas e expressões faciais específicas vão resultar em respostas específicas, para cada espécie (Martinez \& Matsuzawa, 2009). É possível pensar, então, que o reconhecimento de emoções acontece quando repetidas interações sociais com o mesmo indivíduo possibilitam a associação de múltiplas pistas a determinados comportamentos.

Existem muitas dicas sensoriais para a avaliação da emoção dos indivíduos e o tipo de informação que é importante pode variar. Para seres humanos, por exemplo, as expressões faciais desempenham um papel vital (Nagasawa et al., 2011). Em uma inspeção inicial, as faces provêm informações sobre o sexo, idade, identidade individual, emoção (Parr et al., 2000), reações e intenções. Além disso, expressões faciais são um importante modo de comunicar emoções. Por isso, a habilidade de reconhecer as dicas faciais e responder apropriadamente a elas desempenha um papel importante na comunicação social (Bruce \& Young, 1986). Gothard et al. (2003) acreditam que uma diferenciação e avaliação rápida de expressões faciais agonísticas ou afiliativas pode ser um imperativo para sobrevivência.

Indivíduos não respondem simplesmente a estímulos sociais específicos, mas interagem com um campo social complexo, dependente do comportamento e motivação dos outros (Parr et al., 2000). Reconhecer emoções permite a detecção do estado ou reação emocional do outro e isto pode nos proporcionar dicas sobre como responder e nos comportar em situações sociais. De acordo com Nagasawa et al. (2011), conhecer o estado emocional dos outros é de extrema importância para animais sociais para decisão de seus comportamentos futuros e, por isso, pode afetar na sobrevivência dos indivíduos, tornando-se uma característica adaptativa. A capacidade de perceber as emoções do outro pode ter as 
seguintes vantagens biológicas: evitar danos, acessar fontes de alimento e administrar relações sociais. De acordo com Racca et al. (2012), apesar dos mecanismos de obtenção de informação emocional terem sido desenvolvidos numa esfera intraespecífica, um processamento acurado das expressões faciais de um indivíduo pode ser muito vantajoso em relacionamentos interespecíficos, como é o caso do cão doméstico e do ser humano.

Cães domésticos são animais muito sociais e apresentam muitos métodos de comunicação visual como os lobos, incluindo posturas e expressões faciais que podem indicar status, agressão e outras emoções (Nagasawa et al., 2011). Cães se baseiam em dicas visuais para comunicação social intraespecífica. Eles exibem várias expressões faciais (i.e. agressividade, medo), o que é muito importante para comunicação entre coespecíficos (Feddersen-Petersen, 2005).

A habilidade de extrair informações das faces e responder apropriadamente a elas pode acarretar em vantagens seletivas tanto nas interações intraespecíficas quanto nas interespecíficas, entre cães e seres humanos, especialmente quando o conteúdo emocional dessas faces pode ser de significância comportamental adaptativa imediata para os cães domésticos (Guo et al., 2009).

\subsection{Os cães e as emoções}

Cães são capazes de extrair várias informações de situações sociais, entre cães e entre cães e seres humanos, envolvendo processos cognitivos complexos através dos quais são capazes de integrar informações ambientais e sociais para planejar seu comportamento.

Em 2007, Quaranta e colaboradores estudaram o balançar de cauda de cães domésticos frente a diferentes estímulos de duas classes. Usaram estímulos negativos: cão dominante e gato; e estímulos positivos: tutor. Observaram que os cães apresentam maior amplitude do balançar de cauda para o lado direito (controlado pelo hemisfério esquerdo do cérebro) quando o estímulo provoca respostas de aproximação (i.e. tutor) e maior amplitude do balançar de cauda para o lado esquerdo (controlado pelo hemisfério direito do cérebro) quando o estímulo provoca uma resposta de recuo (i.e. cão dominante). Partindo dos achados de Quaranta et al. (2007) de que há assimetria bilateral da amplitude do balançar de cauda em cães domésticos (respostas de aproximação, para direita; respostas de evitação, para a esquerda) e que isso pode estar relacionada com uma dominância hemisférica, Artelle e 
colaboradores (2011) investigaram em que medida o balançar de cauda é informativo para outros cães. A cauda é um instrumento muito importante na comunicação intraespecífica em todos os canídeos, provendo informações visuais aos coespecíficos que podem levar a diferentes comportamentos. Os pesquisadores desenvolveram uma réplica de cão robô que apresentava assimetria no balançar de cauda e avaliaram o comportamento de aproximação de cães livres a ele. Foi observado que os cães se aproximaram da réplica de maneira mais contínua (sem paradas) quando a cauda balançava mais para a esquerda, enquanto para as situações de cauda balançando para direita foi o contrário. Isto mostra que a assimetria no balançar de cauda tem uma função informativa, provendo informações importantes para os animais que vão levar a diferentes respostas comportamentais nos sujeitos. No entanto, entendendo-se que o hemisfério cerebral direito estaria mais ligado ao processamento de emoções negativas e o esquerdo ao processamento de emoções positivas, respostas comportamentais opostas eram esperadas.

Em 2010, Siniscalchi et al., investigando uma possível lateralização visual, descobriram que apresentando estímulos emocionais (silhueta de cão, de gato e de cobra) simultaneamente do lado direito e do lado esquerdo, os cães viraram preferencialmente a cabeça para o lado esquerdo em resposta à imagem da silhueta do gato e da cobra, enquanto para a silhueta do cão não houve viés de movimento de cabeça. Isto indica uma especialização do hemisfério direito do cérebro em relação a emoções intensas, como agressão, comportamento de fuga e medo, como já visto em outras espécies. Além disso, quando os estímulos foram apresentados um de cada vez (de cada lado) houve uma diferença entre as respostas para os estímulos: os cães reagiram mais rapidamente e demoraram mais a voltar a comer quando as imagens eram de gato e cobra, o que demonstra um tipo responsividade diferenciada para os diferentes estímulos.

Siniscalchi e colaboradores (2011) continuaram as investigações de lateralidade no processamento de informação emocional, mas em um outro e importante sentido para os cães: o olfato. Estudaram a utilização da narina direita e da narina esquerda em sujeitos que espontaneamente se aproximavam e cheiravam diferentes estímulos olfativos com conteúdos emocionais distintos (comida, limão, secreção vaginal de fềmeas, adrenalina, suor do veterinário do cão). Quando cheiravam estímulos novos e não aversivos, os cães apresentaram uma preferência inicial pela narina direita, seguida por mudança para a narina esquerda. Quando cheiravam estímulos que causam excitação, como a adrenalina e o suor do veterinário (caráter negativo por estar associado a práticas desconfortáveis), os sujeitos mostraram uma preferência consistente pela narina direita. Isto sugere que o hemisfério direito está envolvido 
no processamento de estímulos novos; quando o estímulo passa a ser conhecido, o hemisfério esquerdo assume o controle do processamento. $\mathrm{O}$ hemisfério direito parece estar relacionado com um processamento mais refinado de estímulos olfativos, o que é necessário para estímulos de importância biológica, como os de caráter negativo.

Apesar de haver uma literatura sobre lateralidade em cães domésticos, estudos de assimetrias na percepção e na produção de expressões faciais estão apenas começando.

\subsection{Os cães, as emoções e as expressões faciais}

A exploração visual do nosso ambiente envolve uma série de ações (juntamente a movimentos de cabeça e do corpo, que cães geralmente usam) para direcionar o olhar para regiões informativas e interessantes. De acordo com Williams et al. (2011), as regiões preferidas de uma cena são geralmente inspecionadas primeiro e atraem um tempo de observação maior. Padrões de olhar provêm um índice comportamental de processamento perceptual e cognitivo e podem ser índices sensíveis de atenção, motivação e preferência, especialmente quando explorando cenas de alto valor ecológico (Henderson, 2003).

Segundo Schmidt e Cohn (2001), diferenças no processamento de expressões faciais se relacionam com diferenças em respostas adaptativas às expressões. Especializações neurobiológicas para o processamento de expressões faciais também podem estar relacionadas ao fato de a percepção de alguns sinais requererem graus de sensibilidade diferentes: a percepção da raiva em níveis muito sutis, por exemplo, pode conferir uma vantagem adaptativa.

Segundo Nagasawa et al. (2011), é possível que os cães domésticos possam reconhecer a face e associar as expressões emocionais humanas a consequências específicas. Cães conseguem discriminar expressões faciais humanas apesar da estrutura facial deles ser muito diferente da dos seres humanos e, nesse sentido, a experiência com pessoas é um aspecto importante. Por outro lado, como é esperado dentro de uma espécie, cães também se baseiam em dicas visuais para comunicação social intraespecífica. Eles exibem várias expressões faciais (i.e. agressividade, medo), o que é muito importante para comunicação entre coespecíficos (Feddersen-Petersen, 2005).

Muitos pesquisadores sugerem que o desenvolvimento de processos cognitivos de reconhecimento de pistas faciais apoia-se na experiência extensiva com certos tipos de faces. 
De acordo com Racca et al. (2010), indivíduos podem passar a serem capazes de discriminar faces a que não estavam acostumados após um período de exposição a elas. É possível assumir, então, que a experiência desempenha um papel determinante no processamento de faces. Adultos humanos podem criar representações mentais da face como um protótipo que é afinado com estímulos faciais frequentemente observados, com faces individuais codificadas em termos de desvio daquele protótipo (Pascalis et al., 2002).

Em 2010, Racca et al., fazendo uso de um paradigma de discriminação de imagens (Comparação Visual Pareada), descobriram que a capacidade de diferenciar faces individuais com base apenas em pistas visuais, já conhecida em primatas humanos e não humanos, também é apresentada por cães domésticos. Cães domésticos são capazes de discriminar faces individuais de cães e de pessoas usando informação visual apenas. O estudo também mostrou que existe uma diferença de processamento específico para diferentes tipos de estímulos visuais (objeto, face humana, face de cão), uma vez que a resposta de olhar diferiu de acordo com o tipo de face envolvido. Os animais olharam mais para a imagem nova e menos para a imagem familiar no caso de objetos e faces humanas e olharam mais para a imagem familiar e menos para a imagem nova no caso de faces de cães, o que pode ser produto de tipos de processamentos de face diferentes para os dois tipos de estímulo.

Já é sabido que o processamento visual de emoções em humanos e não humanos envolve lateralização cerebral. Espécies com dois olhos na frente da cabeça usam a visão binocular contínua, em que cada campo visual é controlado por um hemisfério cerebral contralateral. A preferência por um campo visual pode ser observada através do comportamento de olhar e está associada com o engajamento do hemisfério oposto (Racca et al., 2012).

Guo e colaboradores, em 2009, na Universidade de Lincoln (Reino Unido), sugeriram que uma lateralização funcional do cérebro na percepção e cognição não é um atributo unicamente humano, mas existe em outras espécies de animais não humanos que pode ter sido moldada pela pressão seletiva de viver em ambientes sociais complexos e em que há intensa comunicação social, tendo assim um significado adaptativo - de acordo com Siniscalchi et al. (2010), a lateralização das funções cerebrais já foi comprovada para vertebrados e invertebrados. Guo et al. (2009) mostraram que cães apresentam um viés de olhar para esquerda para inspecionar uma face humana neutra, ou seja, olham primeiro para o lado direito da face da pessoa, principalmente para emoções de caráter negativo (i.e. raiva). Este mesmo viés, que é observado comumente em pessoas (Guo et al., 2010 e 2012), é conhecido 
como a tendência de olhar para a esquerda (TOE) ${ }^{1}$. Este viés é definido como a alta probabilidade da primeira olhada ser para o lado esquerdo e a alta proporção do tempo de observação direcionado para a hemi-face direita do observado, quando ativamente explorando faces (Butler et al.., 2005).

Guo et al. (2009) descobriram que macacos Rhesus criados em laboratório mostraram a TOE para todas as faces (mesmo padrões dos humanos), mas que cães apenas apresentaram este padrão para faces de pessoas (não para outros cães, macacos ou objetos). Ou seja, para os cães, existe uma especialização deste padrão. Parece provável que a informação afetiva e semântica contida nas faces com significado comportamental adaptativo para os cães seja o maior determinante da tendência de olhar para a esquerda, que está ativamente envolvido no processamento de informações relevantes a partir de dicas faciais. A TOE direciona a atenção do cão para a hemi-face direita do tutor e isto pode ajudar o observador a detectar e reconhecer informações biologicamente importantes mais rapidamente e de forma mais precisa nas faces de significância funcional. É possível que cães domésticos apresentem uma tendência biológica de apresentar esse viés e que essa tendência se desenvolva ao longo da vida, em contato íntimo com pessoas.

Também em 2009, Morisaki e colaboradores realizaram um estudo sobre a capacidade de percepção de emoções em cães: examinaram se o comportamento de cães domésticos mudava de acordo com o estado emocional de seus turores. Filmaram cães enquanto observavam seu tutor a assistir duas categorias de vídeo: que elicitava emoções positivas (alegria) e que elicitava emoções negativas (tristeza). Os resultados mostraram que os cães olharam por um período maior de tempo quando seu tutor assitia o filme alegre. Os autores argumentam que essa é uma evidência de que os cães são sensíveis às emoções dos seres humanos.

Segundo Nagasawa et al. (2011), é possível que cães domésticos possam reconhecer a face e associar as expressões emocionais humanas a consequências específicas. Usaram uma tarefa de dupla escolha para verificar se cães são capazes de aprender a discriminar entre uma face humana neutra e uma face humana sorridente e se são capazes de generalizar a expressão "sorriso". Os animais foram capazes de fazê-lo via condicionamento e também de generalizar as expressões sorridentes nas faces de pessoas do mesmo sexo de seu tutor - cães colocam seu foco nas informações dadas pelo seu tutor e é possível que isso gere uma capacidade de generalização dependente do sexo.

\footnotetext{
${ }^{1}$ Em inglês, a tendência de olhar para a esquerda é conhecida como Left Gaze Bias, ou LGB.
} 
O grupo de Nagasawa utilizou uma tarefa de discriminação operante (treinaram cães para tocar em uma tela sensível ao toque sempre que aparecesse uma face sorridente) e foi o primeiro a estudar a capacidade dos cães de discriminar expressões faciais em humanos. No entanto, é necessário apontar algumas dificuldades metodológicas do seu estudo. Em primeiro lugar, devido ao tipo de teste escolhido, era necessário que os cães aprendessem (via treinamento) a escolher sempre faces sorrindo e, tocando na fotografia certa, ganhavam recompensa. Isto fez com que o processo todo (treino + teste) se tornasse longo e cansativo, introduzindo incertezas na interpretação dos resultados (i.e. cães desmotivados). Além disso, o número de animais analisados foi baixo: um total de cinco cães, o que dificulta a generalização e extrapolação dos resultados obtidos.

Nagasawa e colaboradores também tentaram testar a capacidade discriminativa adicionando faces com expressão de raiva. No entanto, para a discriminação de faces raivosas, os resultados não foram acima do acaso. Isso se deu porque na fase de treino os cães aprenderam a escolher a face sorridente, não a evitar a face neutra. Desta maneira, é necessário fazer este tipo de investigação com o emprego de outra metodologia. Os próprios pesquisadores sugerem que estudos para determinar que partes da face humana estão envolvidas, para entender como se dá o processamento visual em cães e se os cães realmente categorizam expressões são necessários.

O estudo de Deputte e Doll (2011) investigou a habilidade de cães entenderem expressões faciais humanas através de informação visual apenas, ou seja, sem a interferência de qualquer outra pista. Em dois experimentos, um homem e uma mulher exibiam quatro emoções (raiva, alegria, nojo e medo). Foram observados 22 comportamentos nos cães, agrupados em três categorias: aproximação, evitação e reação emocional. Todos os cães reagiram mais a faces emocionais, principalmente com expressão de raiva e de alegria, do que às faces controle (expressão neutra). Apenas cães adultos reagiram de maneira mais ativa à raiva, exibindo comportamentos de evitação, e ao medo, prestando mais atenção. O fato de cães não adultos não terem se comportado da mesma maneira sugere que a exposição repetida aos seres humanos e às suas expressões faciais é necessária para que os cães aprendam como responder a elas. Isso pode sugerir um papel importante da ontogenia sobre essa habilidade.

O estudo de Racca e colaboradores de 2012 foi o primeiro a demonstrar lateralização cerebral no processamento de expressões faciais. O objetivo central foi o de avaliar a sensibilidade de cães domésticos à comunicação facial de outros cães e de seres humanos através de três expressões faciais (positiva ou amigável, neutra e negativa ou ameaçadora) das duas espécies. Foi observado nos cães um processamento diferencial de expressões faciais 
dependente da valência de cada emoção. Os cães em relação a fotos de cães: apresentaram um viés para esquerda (TOE) enquanto olhando uma expressão facial negativa e um viés de olhar para direita enquanto observando expressões faciais positivas, mas não apresentaram nenhum viés para faces neutras. Quando olhando para faces humanas, os cães apresentaram variações de padrão de olhar menos claras, tendo sido observada diferença entre emoções não positivas (neutra e negativa) e positivas: viés de olhar para esquerda para as primeiras e nenhum viés para as segundas. Nesse sentido, os cães podem ter interpretado as faces neutras como potencialmente negativas.

Mais recentemente, Buttelmann e Tomasello (2013) realizaram uma investigação sobre a capacidade de cães domésticos utilizarem expressões emocionais referenciais para localizar comida escondida. Em seu estudo, uma pessoa reagia emocionalmente (felicidade, nojo ou expressão neutra) ao conteúdo "escondido" de duas caixas. Apesar de terem encontrado evidências de que os cães são capazes de reconhecer e usar a informação emocional, os pesquisadores enfrentaram alguns problemas metodológicos.

O experimento funcionava da seguinte maneira: um ator ficava em frente a duas caixas e o cão podia observar o comportamento desse ator. A pessoa olhava para dentro de uma das caixas e respondia com uma expressão facial e uma expressão sonora (alegria ou nojo ou alegria ou neutra). Em seguida, olhava para dentro da outra caixa e expressava a outra emoção. O cão escolhia, então, um dos dois recipientes - é provável que os cães tenham entendido que havia comida nas duas caixas, já que o ator respondia a ambas e isso pode ter sido um agente de confusão no experimento.

Os pesquisadores encontraram que cães testados em laboratório discriminaram entre as expressões de alegria e nojo, escolhendo apropriadamente a caixa, mas não foram capazes de discriminar a expressão de alegria da expressão neutra. Por outro lado, cães testados em campo aberto foram capazes de distinguir as expressões em ambas as condições, mas os próprios autores apontam para a influência de pistas do ambiente no desempenho desses animais. Ainda, apesar de os cães, como um grupo, terem apresentado a habilidade de discriminação, o desempenho individual foi baixo e muitos cães apresentaram um viés por lado.

Quanto ao baixo desempenho na condição Feliz-Neutra, outra questão surge: as expressões emocionais eram sempre acompanhadas de uma vocalização do ator congruente à expressão facial, mas nas situações de face neutra nenhum som era emitido. Os autores apontam, então, para a possibilidade de os sons terem agido como reforçadores e terem, 
assim, tornado o estímulo muito mais saliente, o que facilitaria a discriminação. É possível, inclusive, que os cães tenham usado mais as pistas sonoras na discriminação do que as faciais.

Apesar das dificuldades metodológicas, este é um estudo importante, pois aponta para um possível entendimento dos cães sobre as expressões emocionas dos seres humanos, em relação à valência e ao caráter referencial das expressões. No entanto, devido às limitações da pesquisa, ainda não é possível afirmar que cães sejam capazes de reconhecer, discriminar e associar um significado funcional às expressões emocionais humanas.

Já é sabido que cães apresentam uma série de capacidades quanto ao processamento da face, no entanto, ainda há muitos aspectos que precisam ser investigados. Além de não se saber se o processamento de faces ocorre através do mesmo mecanismo neural apresentado por seres humanos, ainda não existem evidências claras de obtenção de informação emocional desses sinais visuais.

\subsection{Os cães, as emoções e as vocalizações}

Quanto à discriminação de vocalizações ligada ao reconhecimento de informações emocionais, ainda é pequeno o número de estudos, inclusive em comparação com estudos de percepção visual. No entanto, algumas pesquisas foram realizadas nos últimos anos e trouxeram evidências importantes de que os cães domésticos são capazes de reconhecer e discriminar sinais comunicativos acústicos.

Siniscalchi e colaboradores (2008 e 2013) realizaram estudos que trouxeram evidências dessa habilidade. Em 2008, investigaram o uso dos dois hemisférios cerebrais no processamento de diferentes estímulos acústicos (i.e. som de trovões e vocalizações). Os resultados mostraram um uso diferencial dos hemisférios, tendo sido observado um uso mais frequente do hemisfério esquerdo para as vocalizações e do hemisfério direito para o som de trovões. No entanto, quando as vocalizações de coespecíficos possuem um caráter negativo, como o medo, o hemisfério direito é o mais utilizado para o processamento.

Em 2013, fizeram uso de medidas de hormônio para tal: examinaram o nível de cortisol em amostras de pelo de cães em resposta a diferentes estímulos acústicos (vocalizações de outros cães em situações de perturbação, isolamento e brincadeira). Os resultados deste estudo apontaram para uma reatividade comportamental aos sons correlacionada à produção de cortisol. Além disso, registraram comportamentos observáveis 
dos cães durantes os playbacks e a correlação com o tipo de som também foi encontrada.

Ruffman e Morris-Trainor (2011) examinaram se cães domésticos obedeciam mais à proibição de pegar um pedaço de comida se o comando tivesse sido emitido por uma pessoa com um tom de voz agressivo em comparação ao comando emitido por uma pessoa com tom de voz amigável. Os cães, na condição da "voz com raiva" demoraram significativamente mais para se aproximar da comida. Também verificaram a influência da expressão da tristeza através da voz: depois do experimentador cumprimentar o cão, ele se escondia atrás de uma tela e fingia estar chorando ou rindo. Os sujeitos mostraram mais interesse nas situações de simulação de choro do que nas situações de risada, tendo se aproximado mais da tela e levantado mais a cabeça.

Também em 2012, Custance e Mayer, interessados na peculiaridade da relação interespecífica entre cães e seres humanos (duas espécies ao mesmo tempo distantes e próximas), estudaram a resposta desses animais a sinais de sofrimento de pessoas. Os cães direcionaram significativamente mais seu comportamento para pessoa chorando do que a em silêncio, independente se a pessoa era seu tutor ou um estranho. A maioria dos cães se comportou de maneira consistente com o que se é esperado em uma resposta empática e de oferecimento de ajuda ao outro: os sujeitos responderam a seu tutor e à pessoa estranha quando estavam chorando de uma maneira significativamente diferente quando comparado com as respostas ao falar e ao produzir um zumbido. Os cães olharam mais, se aproximaram e tocaram mais a pessoa na condição do choro do que nas outras. Além disso, o tipo de aproximação aconteceu de forma diferente: a grande maioria dos cães se aproximou da pessoa chorando de uma maneira submissa, ao invés de tomarem uma postura de brincadeira, calma ou de alerta. O fato dos cães terem diferenciado sua resposta entre o choro e o zumbido significa que eles não estavam simplesmente sendo conduzidos pela curiosidade. Também encontraram que os cães olharam mais para a pessoa que estava "zumbindo" do que quando simplesmente falava, o que indica que diferenciaram também estas duas condições, mas que atribuíram diferentes valores a elas.

Em um comportamento empático, o sujeito experiencia uma reação emocional em resposta ao estado emocional do outro, porém sem confundir seu próprio estado emocional. Portanto, empatia requer a habilidade de discriminação entre o self e o outro (de Waal, 2008). Um indicador de empatia pode ser o comportamento de ajudar e/ou de oferecer conforto a alguém em resposta a um display de perturbação (Custance \& Mayer, 2012). Como demonstrado por Custance e Mayer (2012), a resposta dos cães domésticos ao choro de pessoas não parece ser simplesmente o produto de um contágio emocional ou de uma 
perturbação causado pela demonstração emocional do outro. Izard (2009) sugere que o componente cognitivo interagindo com componente emocional deve transformar a empatia em um comportamento cooperativo. Partindo dessa discussão, é possível pensar que cães sejam capazes de ler e interpretar informação emocional de outros animais (cães e seres humanos) e estudos sistemáticos nesse sentido são necessários.

\subsection{Reconhecimento cross $^{2}$-modal}

As interações entre um indivíduo e o mundo são multidimensionais e envolvem, simultaneamente, sinais provindos de diferentes canais perceptivos (Deputte \& Doll, 2011). Ser capaz de reconhecer um objeto de uma maneira cross-modal significa perceber as informações provindas, por exemplo, do canal visual e do canal auditivo e associá-las categoricamente (Taylor et al., 2011): ouvir o nome de um objeto enquanto se visualiza este objeto - ou a imagem dele - influencia (e facilita) a resposta de processamento daquele estímulo visual.

Em situações naturais, a informação de um dado objeto é compatível em diferentes modalides sensoriais (Yuval-Greenberg \& Deouell, 2009). Reconhecimento cross-modal é a habilidade do cérebro de identificar um indivíduo ou um objeto através da interação dos sentidos. Ocorre integração de pistas de diferentes modalidades em uma representação cognitiva que possibilita que o cérebro substitua a informação de um módulo perceptivo para outro (Calvert, 2001).

Armazenada em uma memória de longo prazo, esse tipo de representação multimodal possibilita que um indivíduo, quando desprovido de um ou outro sentido, possa manter sua capacidade de reconhecimento de imagens, sons ou cheiros (Lampe \& Andre, 2012). A natureza cross-modal do reconhecimento possibilita, por exemplo, que um indivíduo forme uma imagem mental de um sujeito ao ouvir sua vocalização (Adachi \& Fujita, 2007).

Podemos retirar de cada estímulo informações de categorias sensoriais distintas que, em conjunto, auxiliam na representação que criamos dos objetos e dos outros animais. Essa redundância de informação é a chave para um reconhecimento mais apurado e mais rápido

\footnotetext{
2 O termo cross-modal será empregado no texto em inglês por não existir um substituto equivalente em português. Reconhecimento cross-modal é um tipo de reconhecimento multimodal, que utiliza informações de canais perceptivos diferentes de maneira integrada.
} 
(Yuval-Greenberg \& Deouell, 2009). Por exemplo, o conceito que as pessoas têm de cães não contém apenas as várias formas das diferentes raças, mas também as vocalizações, os cheiros, entre outras características de categorias perceptuais muito diferentes.

Animais são seres equipados de canais sensoriais múltiplos pelos quais experienciam o ambiente e cada sentido fornece informações qualitativas sobre o mundo. Muitos estímulos não possuem contrapartes equivalentes em um e outro canal perceptivo, mas, através das habilidades cross-modais, animais são capazes de manter uma percepção coerente e unificada do que está em sua volta. Essas capacidades conferem vantagens comportamentais importantes (Calvert 2001). Porque informações provindas dos diferentes sentidos são tipicamente complementares, a integração cross-modal pode fornecer informações sobre o ambiente que são impossíveis de obter de forma isolada.

Esse intercâmbio de informações entre as várias modalidades sensoriais é muito útil, uma vez que a modalidade disponível em um determinado momento pode não ser a mesma em outro. Por exemplo, se um animal tem como modalidade perceptual mais avançada a visão, é interessante poder usar informações de outras modalidades para formar uma imagem mental quando a visão está obstruída (Adachi \& Fujita, 2007). De acordo com YuvalGreenberg \& Deouell (2009), quando as condições não são ótimas, erros perceptuais podem acarretar em incongruência e, assim, criar conflitos cross-modais. A percepção visual é direcional e pode ser afetada pela distância e visibilidade. Isto pode acarretar uma vantagem adaptativa relativa do domínio acústico na percepção e na avaliação de algumas situações (Taylor et al., 2011).

O processamento discriminativo pode acontecer em diferentes níveis perceptuais e envolve diferentes tipos de informação. Por exemplo, animais podem aprender a discriminar estímulos visuais usando características fisicas de imagens sem necessariamente reconhecer os objetos representados nas figuras (Adachi \& Fujita, 2007). Devido a este aspecto, o reconhecimento verdadeiro pode ser definido como a associação de pistas múltiplas dentro e entre modalidades (Kondo et al., 2012) - isto iria excluir qualquer discriminação fisica simples. É possível, então, estender a ideia do reconhecimento verdadeiro para a percepção cross modal, uma vez que esta envolve informações de diferentes canais sensoriais. Além disso, dizer que um animal é capaz de reconhecimento cross modal significa que mais do que perceber os estímulos em um domínio, o cérebro pode integrar as informações em uma representação de alta ordem independente de modalidade (Proops et al., 2009).

Ser capaz de reconhecer um objeto ou um indivíduo através de informações cross modais como a face e a voz implica que um sujeito gera uma imagem visual quando escuta 
um som ou uma vocalização, por exemplo (Adachi et al., 2007). Reconhecimento real requer não somente a discriminação entre pistas e a integração da informação de diferentes canais, mas também a associação entre as pistas sensoriais sendo obtidas com a informação armazenada sobre aquele estímulo específico. Isto significa que um indivíduo precisa ter experiência com o estímulo - e uma representação mental tem que ter sido gerada e armazenada na memória - para que no processo de discriminação este indivíduo possa comparar as informações obtidas do estímulo com a representação cognitiva que ele construiu. Portanto, quando se trata de emoções, um fator essencial é o grau de exposição e interação com aquele tipo de estímulo. De acordo com Adachi e colaboradores (2007), cada exemplar de conceito natural que pessoas possuem devem levar à geração de uma representação típica ou específica daquele conceito e, por isso, abordagens cognitivas comparativas são essenciais para entender como as habilidades de categorização teriam evoluído.

A maioria das interações sociais em humanos envolve combinar informações de face e voz de outros indivíduo e este pode ser o caso para outros animais sociais. Explorar redundâncias entre estas diferentes informações do mesmo estímulo aumenta a fidedignidade do processo de reconhecimento (Campanella \& Belin, 2007). Estudos sobre a percepção acústico-visual demonstraram que informações combinadas extraídas da face e da voz possibilitam um reconhecimento mais rápido e mais robusto em comparação com situações que somente envolvem pistas unimodais (Martinez \& Matsuzawa, 2009).

Sistemas de comunicação animal envolvem sinais multimodais complexos compostos de combinações e sequências de diferentes componentes sensoriais que vão ser percebidos de uma maneira unificada (Parr, 2004). Pesquisas com seres humanos demonstram que integração cross modal de informações emocionais é um processo complexo que não pode ser relacionado a um único evento neural acontecendo em uma única região do cérebro. Pelo contrário, envolve uma rede interativa, na qual a atividade é distribuída no tempo e no espaço (Campanella \& Belin, 2007).

A habilidade de processar informação audiovisual deve desempenhar um papel importante nas interações sociais e na manutenção da coesão do grupo, uma vez que ajuda no reconhecimento dos indivíduos e de seus estados emocionais (Martinez \& Matsuzawa, 2009). A habilidade de perceber emoções nos outros é um dos fatores mais importantes envolvidos das interações sociais em vários animais. Tal capacidade funciona como ferramenta para coordenar atividades entre membros de um mesmo grupo, para possibilitar a formação de relações de longo-prazo (Parr et al., 2000). 
O reconhecimento de emoções permite a avaliação do estado emocional e das reações do outro, o que confere informações sobre como um indivíduo deve responder e como deve se comportar em contexto social. Uma discriminação e avaliação rápida de expressões faciais (positivas ou negativas) podem ser um imperativo para a sobrevivência de muitos animais (Gothard et al., 2003) e o reconhecimento cross-modal pode possibilitar isso a um indivíduo.

\subsection{Reconhecimento cross-modal em não humanos}

Para animais sociais, a integração cross-modal para reconhecimento de indivíduos e objetos deve ser altamente funcional, uma vez que facilita os processos de leitura do ambiente e proporciona uma experiência perceptual coerente (Taylor et al., 2011). Uma integração cross-modal de pistas de identidade de coespecíficos, por exemplo, pode carregar vantagens evolutivas para um indivíduo (Lampe \& Andre, 2012), principalmente quando se trata de pares com importância ecológica (e.g. faces e vozes).

É possível que o reconhecimento cross modal de objetos e indivíduos possua uma história filogenética muito ampla. Por muito tempo, a habilidade de integrar informação de maneira cross modal foi considerada única para seres humanos - pessoas demonstram vários níveis de representações cross modais desde estágios muito inicias do desenvolvimento. No entanto, foram encontradas evidências de que animais não humanos são capazes de processar informações de uma maneira integrada, envolvendo aspectos cognitivos complexos (i.e. Proops et al., 2009). Atualmente, já existem evidências de reconhecimento cross-modal em vários primatas não humanos, como em chimpanzés, macacos Rhesus, macacos japonenses, macacos prego e do gênero Saimiri. Na última década, trabalhos foram realizados com outras espécies de animais, tendo sido encontrada a habilidade de reconhecimento cross modal em cães (Adachi et al., 2007; Faragó et al., 2010a; Taylor et al., 2011) e em cavalos domésticos (Lampe \& Andre, 2012), além de corvos (Kondo et al., 2012). Além disso, as áreas cerebrais responsáveis pela integração da informação audiovisual e regiões de cérebro sabidas multissensoriais já foram encontradas em primatas não humanos (Proops et al., 2009).

Os estudos de Proops et al. (2009) e de Lampe e Andre (2012) mostraram que cavalos domésticos são capazes de reconhecer pessoas de uma maneira cross-modal, ou seja, que são capazes de integrar pistas de identidade multissensoriais de um ser humano familiar em uma representação cognitiva que é independente de uma dada modalidade perceptiva. Cavalos 
domésticos reconheceram humanos familiares quando escutaram suas vozes, mesmo sem vêlos ou sem cheirá-los. Cavalos responderam mais rapidamente e olharam por mais tempo quando o som não era congruente ao estímulo visual, indicando que as combinações incongruentes violaram suas expectativas. Isto significa que cavalos domésticos são capazes de reconhecer indivíduos de maneira cross modal e que o fazem de forma precisa o suficiente para discriminar entre dois indivíduos altamente familiares.

No estudo realizado por Proops e McComb, em 2012, os cavalos olharam por mais tempo e responderam mais rápido quando se tratava do tutor, em comparação com uma pessoa estranha. No entanto, esse fenômeno foi apenas observado quando o tutor estava posicionado no lado direito do animal. Os sujeitos associaram o tratador com sua voz mais facilmente quando a pessoa estava do seu lado direito; as fềmeas responderam melhor no reconhecimento de seus tratadores e os cavalos mais novos mostraram menor latência para responder ao estímulo acústico. Além disso, os cavalos em geral não olharam por mais tempo para a pessoa estranha quando ouvindo a voz não familiar.

Também em 2012, Kondo e colaboradores investigaram a capacidade de reconhcer coespecíficos de maneira cross-modal em corvos. Utilizaram um paradigma de violação de expectativa e observaram que os sujeitos olharam por períodos mais longos de tempo e com uma latência menor nas condições de estímulo incongruente, quando ouviram a voz de um indivíduo e viram a imagem de outro em seguida, indicando que esses animais criaram uma expectativa ao ouvir a vocalização de um indivíduo. No entanto, isto só foi observado quando o estímulo era um membro do seu grupo (identidade do som e da imagem familiar), mas o mesmo não foi visto para não membros.

Esses resultados com cavalos e corvos sugerem que um contato social regular pode possuir um papel importante no desenvolvimento da capacidade de reconhecimento cross modal de indivíduos, demonstrando um fenômeno lógico: não é possível reconhecer um estímulo quando não há experiência com o mesmo.

\subsection{Os cães e o reconhecimento cross-modal}

Em 2007, Adachi e colaboradores trabalharam com cães domésticos e apresentaram a eles uma foto de seu tutor ou uma foto de um estranho depois de serem expostos ao som da voz de um dos dois (playback). A voz e a face eram corretamente pareadas em metade das 
tentativas (condição congruente) e não na outra metade (condição incongruente). Os cães olharam durante mais tempo para o estímulo nas situações em que voz e rosto não eram da mesma pessoa, o que sugere um estranhamento nessa situação. Os achados sugerem que cães ativaram uma representação interna da face do seu tutor quando ouviram a voz deles.

Faragó e colaboradores (2010a) utilizaram um paradigma de preferência de olhar para investigar as expectativas geradas pelo cão sobre o tamanho do corpo do sinalizador a partir de seus rosnados. Medir o comportamento de olhar dos cães possibilitou aos pesquisadores avaliar sua habilidade de obter informações sobre o tamanho corporal através do uso de informações provindas do sinal acústico. Quando deparados com duas images de cães enquanto ouviam um rosnado, os cães olharam primeiro e por mais tempo para a figura que combinava com o tamanho do cão produtor daquele rosnado do que para a figura maior ou menor. Isto signifca que esses animais fizeram a ligação entre a pista acústica de tamanho com a informação visual. No entanto, os sujeitos não generalizaram a pista acústica de tamanho para todos os estímulos: o fizeram para figuras de cães, mas não para figuras de gatos ou para triângulos. Isto sugere que cães são capazes de ativar uma representação mental do sinalizador tanto em relação à espécie quanto ao tamanho.

Outro achado interessante do trabalho de Faragó e colaboradores (2010a) foi que os cães prestaram mais atenção às fotos de outros cães e de gatos do que para imagens de figuras geométricas, o que mostra que eles diferenciam categorias de imagens. Além disso, o fato dos sujeitos apresentarem preferência em direção à combinação de cão com rosnado mostra que esses animais vêem os cães como cães, diferentes de gatos. Esses resultados estão em congruência com os achados de Range e colaboradores (2008) e de Somppi e colaboradores (2012), de que cães domésticos são capazes de classificar fotografias de categorias diferentes através de mecanismos perceptuais distintos.

Taylor e colabradores (2011) também investigaram se cães domésticos são capazes de combinar espontaneamente informações do rosnado de um cão com categorias visuais de tamanho correspondentes. No entanto, ao invés de imagens, utilizaram réplicas de cães de diferentes tamanhos. Os resultados corroboram os achados mencionados acima. A integração da informação acústica sobre o tamanho do corpo provavelmente não é uma consequência da domesticação ou das variações entre as diferentes raças de cães domésticos. Os autores argumentam que esta deva ser uma característica selecionada em uma série de animais. Além disso, a integração cross-modal das pistas sensoriais não deve estar restrita ao tamanho de corpo, mas deve ser funcional para uma série de características. Por isso, é necessário que sejam realizados experimentos que investiguem como os cães categorizam outros tipos de 
estímulo, entre eles os emocionais.

As evidências sugerem que, assim como primatas humanos e não humanos, cães possuem a habilidade de gerar uma representação mental do sinalizador a partir de um sinal acústico do mesmo e podem combinar esta representação com características de outras modalidades. No entanto, nenhum estudo ainda abordou o reconhecimento cross-modal de estímulos com conteúdo emocional - um aspecto de grande importância em se tratando de animais sociais - e isto abre espaço para novas e importantes investigações.

\subsection{O estudo do reconhecimento cross-modal}

Miklósi (2007) assume que existe uma grande sobreposição entre o comportamento humano e o comportamento de cães domésticos devido ao contato próximo entre grupos das duas espécies, em que evoluiu uma similaridade em várias habilidades sociais. Cães e pessoas fazem parte de um contexto social único, em que é interessante compreender aspectos psicológicos um do outro.

O contato sensorial de um animal com um estímulo visual pode ser avaliado (1) através do tempo relativo dedicado em atenção (olhar espontâneo) a este estímulo em contraste com o outro do qual deveria ser distinguido ou (2) através dos movimentos oculares centrados num e noutro estímulo.

De acordo com Williams et al. (2011), o estudo do movimento dos olhos e da alocação da atenção visual em cães permite a investigação de diversos fatores e permite explorar como os estímulos visuais influenciam o comportamento dos cães, assim como de que forma esses estímulos são processados pelo sistema visual e como a atenção está relacionada a esses processos.

A grande maioria dos estudos do comportamento visual de cães é feito por meio do uso de técnicas que medem as mudanças na orientação do corpo e da cabeça ou que verificam a direção do olhar (Gácsi et al., 2004; Virányi et al., 2004; Adachi et al., 2007; Guo et al., 2009; Siniscalchi et al., 2010; Racca et al., 2010; Faragó et al., 2010a; Taylor et al., 2011; Racca et al., 2012).

As duas principais maneiras de acessar a habilidade de reconhecimento cross modal, em que são apresentados tanto estímulos sonoros quanto visuais e a resposta é medida pelo comportamento de olhar, são o paradigma de violação de expectativa (PVE) e o paradigma de 
preferência de olhar (PPO). Os dois métodos são úteis, uma vez que é possível verificar a associação espontânea de múltiplas pistas de um estímulo por um sujeito. No PVE, o sujeito precisa acessar mais sua memória, uma vez que as diferentes categorias de estímulos aparecem em sequência (uma depois da outra). No PVE, a apresentação de uma pista específica (e.g. vocalização) ativa alguma forma de representação multimodal pré-existente que cria uma expectativa para o estímulo que aparecerá em seguida (e.g. face). A expectativa será quebrada com o par de estímulos incongruentes e uma resposta mais rápida e um comportamento de olhar mais longo serão observados. Por outro lado, no PPO, a representação interna pode ser comparada com as duas faces, uma congruente e uma incongruente, e uma resposta mais forte será direcionada ao par em que há congruência. A apresentação simultânea de diferentes categorias e de mais de um estímulo visual ao mesmo tempo permite que o sujeito escolha um estímulo, após julgar qual está mais associado ao estímulo sonoro, depois de compará-los. Assim, é possível que o indivíduo faça uma avaliação de que a combinação de categorias se aproxima mais da representação mental que já possui armazenada em sua memória. Respostas opostas, em relação ao tempo de olhada para o estímulo congruente e o estímulo congruente, são esperadas para os dois paradigmas e isto esta relacionado com a simultaneidade da apresentação do estímulo sonoro e visual.

O paradigma de olhar preferencial é muito usado com humanos e com primatas não humanos para testar as habilidades de combinar um estímulo auditivo com o visual. Para cães, o paradigma de preferência de olhar configura um método bastante interessante no estudo de aspectos cognitivos e foi a nossa escolha para o presente estudo na investigação da percepção das emoções de cães e de seres humanos.

\subsection{Justificativa}

Cães são sujeitos interessantes em estudos de cognição social, uma vez que são uma espécie social e são sensíveis a pistas comunicativas, inclusive humanas. Nas últimas décadas, o número de trabalhos com cães como um animal modelo no estudo de aspectos psicológicos cresceu muito. No entanto, ainda muitas perguntas permanecem sem resposta e trabalhos investigativos e experimentais são necessários, no sentido de compreender melhor os cães domésticos e suas capacidades cognitivas. Por exemplo, existem poucos estudos com cães domésticos que avaliam a sensibilidade e os mecanismos de percepção das emoções e de 
estados emocionais de outros cães e de seres humanos. Apesar das indicações de que cães são capazes de processar informações de faces e de vocalizações, muitos aspectos ainda são muito pouco conhecidos.

Um estudo sistemático sobre os vários canais ligados à percepção é necessário para mostrar que além de perceber e reagir a estímulos, os cães são capazes de desempenhar uma integração funcional de várias informações provindas de modalidades sensoriais diferentes, integrando o domínio visual e o auditivo, o que facilitaria a percepção dos estados emocionais dos outros indivíduos. O desenvolvimento de processos perceptuais de reconhecimento de emoções em cães domésticos dentro de contextos intraespecíficos e interespecíficos pode ter o papel de coordenar as interações sociais e facilitar a coesão do grupo. Além disso, o reconhecimento cross-modal de objetos e indivíduos pode ser entendido como o reconhecimento verdadeiro. Possuir essa capacidade significa poder criar uma representação mental de ordem mais alta e de se utilizar de habilidades cognitivas mais complexas do que as envolvidas na simples discriminação de características físicas de estímulos.

Investigar como o reconhecimento de objetos e indivíduos ocorre, que mecanismos estão envolvidos na percepção do meio e no que resultam em termo de vantagens para esses animais é muito importante na esfera do estudo sobre os processos de integração de informações e de compreensão do mundo. De acordo com Proops et al. (2009), entender a natureza e a extensão de uma habilidade cognitiva importante como o reconhecimento cross modal pode ser a chave para o entendimento da evolução da comunicação e da cognição animal.

Já é sabido que cães exibem emoções através de expressões faciais e, possivelmente, de vocalizações, que utilizam para se comunicar visualmente e acusticamente com cães e seres humanos. Cães são capazes de ler várias pistas comunicativas humanas e prestam atenção às faces e ao estado de atenção de outros cães e de pessoas. Além disso, existem evidências de que são sensíveis a emoções de ambas as espécies. Por fim, estudos recentes mostraram que cães domésticos podem reconhecer de maneira cross-modal (i.e. associação de voz e face do tutor; obtenção de informação sobre o tamanho de um cão pela imagem e som).

Acreditamos, portanto, que cães domésticos sejam capazes de reconhecer e discriminar emoções de cães e de pessoas de uma maneira cross-modal e que, por isso, apresentem uma preferência de olhar (mais tempo) em direção a um estímulo visual que é congruente ao estímulo sonoro ao qual o sujeito é exposto (expressão facial e vocalização emocional que combinam). O contrário deve ser visto para combinações incongruentes. 


\subsection{Hipótese e objetivos}

O objetivo central desta pesquisa foi testar a hipótese de que cães domésticos (Canis familiaris) são capazes de reconhecer e discriminar expressões faciais e vocalizações de outros cães e de pessoas de maneira cross-modal, ou seja, podem obter e integrar informações emocionais de estímulos visuais e sonoros.

A partir disso, os objetivos específicos constituem a busca por responder algumas questões relacionadas a esta habilidade. Se cães são capazes de reconhecer emoções de maneira cross-modal, existe diferença no desempenho frente a: (i) estímulos caninos e humanos? (ii) estímulos femininos e masculinos? (iii) estímulos positivos e negativos? (iv) estímulos apresentados do lado esquerdo e do lado direito do sujeito? Além disso, existe alguma interação entre o sexo do sujeito e o sexo do estímulo?

Dentro desta perspectiva, algumas predições podem ser estabelecidas e testadas:

a. se cães podem reconhecer emoções de maneira cross modal, espera-se que olhem mais para a imagem congruente quando ouvindo uma vocalização com informação emocional.

b. se a lateralidade cerebral está envolvida no reconhecimento cross modal de emoções, são esperadas diferenças do comportamento de olhar entre o campo visual direito e o campo visual esquerdo do cão. Nesse caso, dois modelos podem ser testados: (i) o campo visual esquerdo favorecido, controlado pelo hemisfério cerebral direito, que estaria responsável pelo processamento de todas as informações emocionais, independente a valência (modelo do hemisfério direito, Borod et al., 1983); (ii) a preferência por um campo visual ou outro dependendo da valência da emoção - hemisfério esquerdo responsável pelo processamento de emoções de valência positiva e hemisfério direito responsável pelo processamento de emoções de valência negativa (modelo de valência, Ehrlichman, 1987)

c. se o sexo do estímulo, a valência do estímulo e/ou a espécie do estímulo exercem algum tipo de influência na qualidade da percepção do conteúdo emocional das faces e vocalizações por cães, espera-se que os sujeitos apresentem uma resposta diferenciada - tempo de olhar maior para uma ou outra imagem - entre estímulos femininos e masculinos, positivos e negativos e/ou caninos e humanos. 
Capítulo 2 - Metodologia 


\section{Metodologia}

\subsection{Participantes}

Os cães que participaram desta pesquisa eram cães que moravam com uma família (cães de familia), socializados, vivendo neste contexto há pelo menos 18 meses. Todos eles atendiam prontamente ao comando de "sentar" e não apresentavam dificuldades em serem manejados por outras pessoas. A pesquisa foi divulgada na internet e na Universidade de Lincoln e um total de 23 cães saudáveis (sem problemas conhecidos de audição, de visão, neurológicos ou crônicos) de várias raças participaram neste estudo (ver tabela) Seis cães tiveram que ser excluídos da amostra devido a problemas técnicos e falta de atenção e/ou inquietação durante os testes, restando um total de 17 cães ( 9 machos; 8 fềmeas) que completaram o experimento com sucesso. As idades variaram entre dois e sete anos e meio

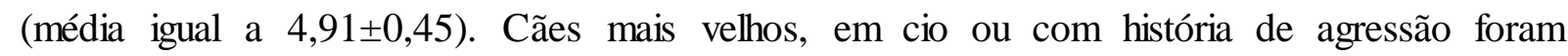
excluídos.

O experimento foi a representação de uma situação considerada natural para os participantes, uma vez que todos eles possuíam experiência com faces de cães e de pessoas e $\mathrm{o}$ procedimento foi inteiramente não invasivo. Nenhum dos sujeitos era familiar às pessoas e cães utilizados como estímulos e a participação de cães e responsáveis foi voluntária. Aprovação ética para este estudo foi concedida pela Universidade de Lincoln (Reino Unido).

Tabela 1. Sujeitos que participaram do experimento.

\begin{tabular}{ccccc}
\hline Cão & Sexo & Raça & $\begin{array}{c}\text { Idade } \\
\text { (anos) }\end{array}$ & Condição \\
\hline Ivo & Macho & Working Sheepdog & 7 & Inteiro \\
Izzie & Fêmea & Bearded Collie & 3 & Castrada \\
Indie & Fêmea & Silken Windhound & 6,5 & Castrada \\
Pippin & Macho & Border Collie & 5 & Castrado \\
Koda & Macho & Rottweiler & 5 & Inteiro \\
Lexi & Fêmea & Cruzamento de Boxer & 7,5 & Castrada \\
Shadow & Macho & Pastor Alemão & 5 & Castrado \\
Lottie & Fêmea & Pointer Alemão Pêlo Curto & 3,5 & Inteira \\
Pippa & Fêmea & Pointer Alemão Pêlo Curto & 3,5 & Inteira \\
Pinto & Macho & Malinoais Belga & 4 & Castrado \\
Riley & Fêmea & Staffy x Whippet & 7 & Castrada \\
Rodney & Macho & Deerhound & 3 & Castrado \\
\hline
\end{tabular}




\begin{tabular}{ccccc}
\hline Nellie & Fêmea & Cruzamento de Cavalier & 3 & Castrada \\
Meg & Fêmea & King Charles & 4 & Castrada \\
Lud & Macho & Labrador & 7,5 & Inteiro \\
Guy & Macho & Labrador & 7 & Inteiro \\
Tyke & Macho & Cruzamento de Border & 2 & Castrado \\
\hline
\end{tabular}

\subsection{Estímulos}

Os estímulos consistiram em oito vocalizações (anexo A) e oito expressões faciais (fig. 1 e 2) obtidas de dois cães adultos (um macho e uma fêmea, ambos da raça Pastor Alemão) e duas pessoas adultas (um homem e uma mulher, ambos caucasianos), como estímulo: todos os sons foram gravados simultaneamente à produção das fotografias para garantir que vocalizações e expressões faciais fossem congruentes.

Para o estímulo acústico de cães, nós gravamos vocalizações durante brincadeira assim como em situações ameaçadoras. Para o estímulo humano, gravamos pessoas falando a mesma frase não familiar de maneira feliz e com raiva. Imagens estáticas dicromáticas (corrigidas para escala de cinzas média) de expressões de brincadeira e agressivas foram obtidas de dois cães de polícia e expressões de felicidade e raiva de pessoas e utilizadas como estímulos neste experimento.

Usamos, então, duas categorias de som para cada espécie: latidos de brincadeira (LB) e latidos agressivos (LA) e a sentença "venha cá" dita de forma feliz (F) e com raiva (R). Estas palavras foram escolhidas porque não continham nenhum sentido para os sujeitos (cães britânicos) e porque podem ser utilizadas em ambos contextos - positivo e negativo - na língua nativa (português brasileiro). Todas as vocalizações foram gravadas em mono e com uma taxa de amostragem de $48 \mathrm{kHz}$. As vocalizações dentro das categorias diferiram em sua estrutura acústica devido a características individuais e as vocalizações entre categorias diferiram no tipo de som. Os parâmetros acústicos "frequência mínima", "frequência máxima", "amplitude de frequência", "energia" e "duração" foram medidos com o programa Raven Pro 1.4 e foram gerados fragmentos de som para cada uma das vocalizações, controlando para energia média e duração de cinco segundos. O som neutro (SN) utilizado como controle (ruído marrom) foi gerado usando o programa Audacity 2.0.2. 
Latidos de cães são vocalizações que podem apresentar variações das suas estruturas acústicas. Categorias de latidos diferentes (emitidos em contextos motivacionais distintos) podem ser discriminadas visualmente por diferenças em parâmetros como frequência, duração e intervalo entre notas (i.e. Yin \& Cowan, 2004). Da mesma forma, é possível reconhecer diferenças contextuais e motivacionais na fala humana através de suas características físicas. Os espectrogramas de cada som podem ser vistos no anexo A (janela: tipo Hann; DFT: 1024; brilho e contraste: 60$)$.

Os estímulos visuais eram fotos digitais de alta qualidade de expressões faciais de pessoas e de cães divididas em duas categorias: positivas ("brincadeira” para cães e "felicidade" para pessoas) e negativas ("agressiva" para cães e "raiva" para pessoas). As fotos foram tiradas com uma câmera SLR (Nikon D70), digitalizadas e apresentadas em escala de cinzas. Brilho e contraste foram visualmente ajustados para serem o mais similares possível entre imagens e entre o lado esquerdo e o lado direito de cada imagem. As faces não possuíam nenhuma marca característica e as pessoas não estavam usando nenhum tipo de joia ou maquiagem. Os estímulos visuais eram imagens em tamanho real e foi utilizada uma barreira $(119,5 \mathrm{~cm} \times 60,0 \mathrm{~cm})$ na frente de cada uma das telas para que a projeção parecesse mais realista para os sujeitos.

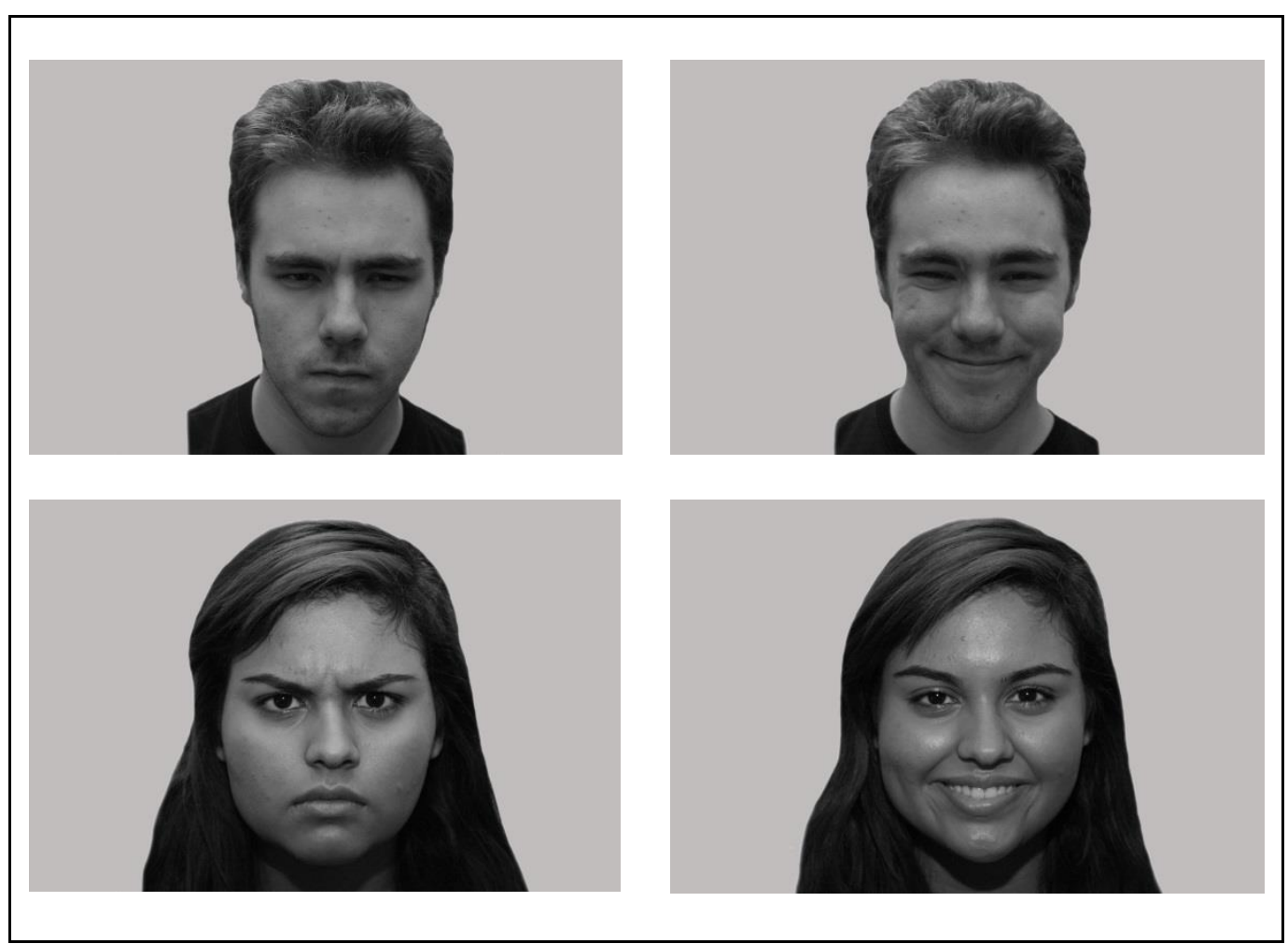

Figura 1. Estímulos visuais humanos (imagens originais): faces de raiva e de alegria de macho e de fêmea. 


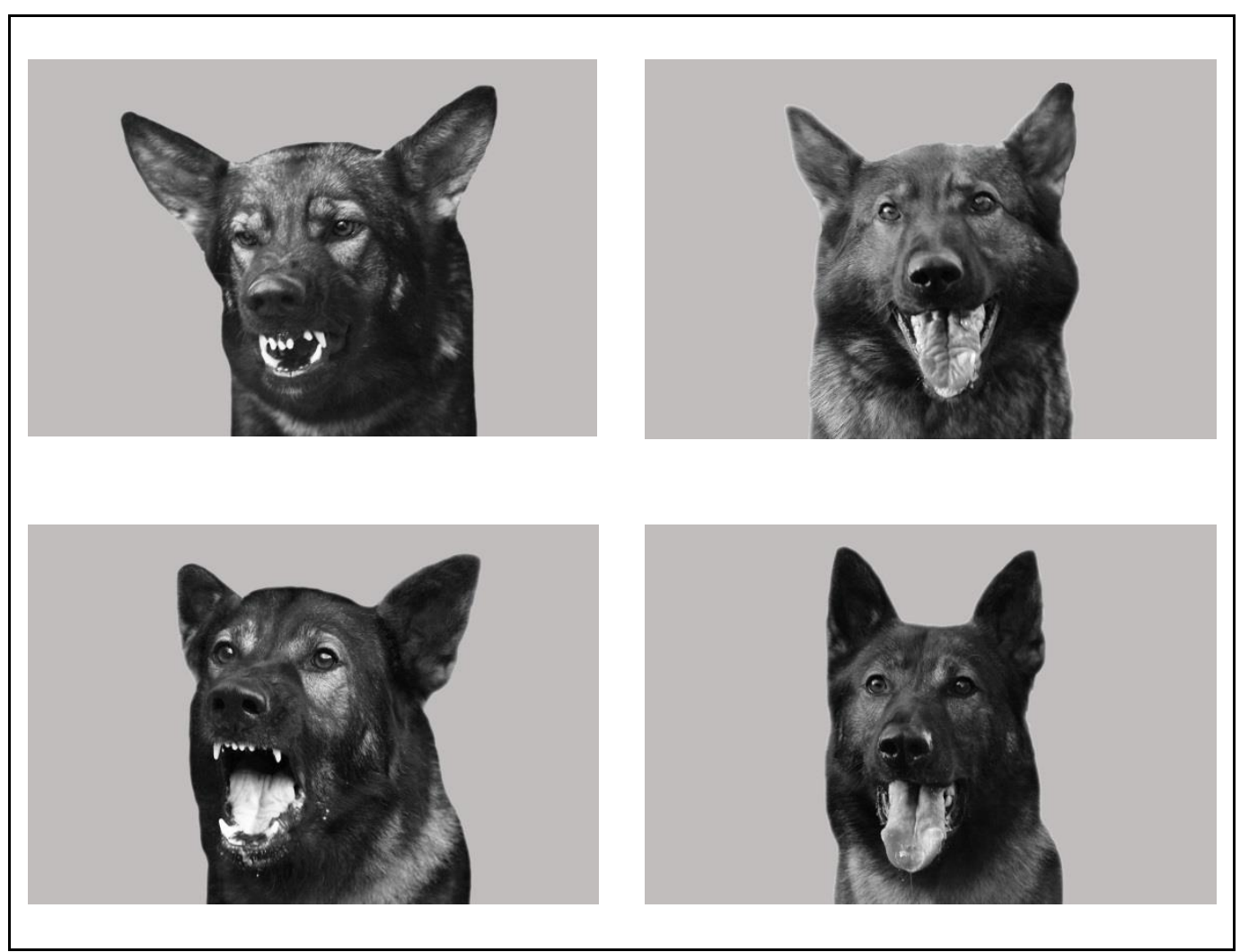

Figura 2. Estímulos visuais caninos (imagens originais): faces agressiva e de brincadeira de fêmea e de macho.

Em relação aos estímulos negativos, fotos foram tiradas e sons foram gravados quando: (i) humanos demonstravam sinais de raiva como sobrancelhas franzidas, olhos tensionados e a boca bem fechada enquanto evocando a emoção de raiva e (ii) cães demonstravam sinais de agressividade como exposição de dentes, focinho franzido e orelhas eretas enquanto, dentro do porta-malas de um carro, uma pessoa e outro cão se aproximavam. Em relação aos estímulos positivos, fotos foram tiradas e sons foram gravados quando: (iii) humanos demonstravam sinais de alegria como sobrancelhas relaxadas, olhos "franzidos" e um sorriso enquanto evocando a emoção de felicidade e (iv) cães demonstravam sinais de comportamento de brincadeira como boca aberta com a língua para fora, focinho relaxado e orelhas eretas enquanto em uma situação de brincadeira com uma pessoa.

Os modelos foram estudantes de artes cênicas da Universidade de Lincoln e cães da Seção de Cães da Polícia de Yorkshire (Reino Unido). Pedia-se às pessoas que evocassem situações geradoras de sentimentos de raiva e de alegria e expressassem estes sentimentos em suas faces e na forma com diziam a frase. Eles estavam em uma sala com isolamento acústico 
e sua voz foi o único som gravado naquele momento. Estímulos caninos foram obtidos durante situações de brincadeira e quando eram abordados dentro do porta-malas de um carro. Durante a gravação dos sons, o cão ficava separado de qualquer outro cão para que não houvesse nenhum tipo de interferência.

\subsection{Desenho experimental}

A coleta de dados foi realizada entre Setembro (2012) e Fevereiro (2013) na Universidade de Lincoln (Lincoln, Reino Unido) utilizando um paradigma de reconhecimento cross-modal de preferência de olhar. Foram utilizadas duas modalidades de estímulo (visual faces e acústica - vocalizações) e duas categorias emocionais (positiva e negativa).

Cada ensaio teve duração de cinco segundos e consistiu na apresentação de uma combinação de estímulos: um par de estímulos visuais (expressão facial positiva e negativa) e apresentação simultânea de uma vocalização - faces e som eram sempre do mesmo indivíduo (mesmo sexo, mesma espécie, valência da emoção diferente). As fotografias de mesmo tamanho foram apresentadas em um fundo homogêneo cinza claro. Cada imagem foi apresentada (projeção por trás) no meio de uma das duas telas, distantes $23 \mathrm{~cm}$ uma da outra. As telas $(183,1 \mathrm{~cm} \times 137,6 \mathrm{~cm})$ estavam localizadas na frente do animal. Havia um painel de madeira com luzes que piscavam entre as duas telas para atrair a atenção dos sujeitos - as luzes só eram ligadas nos intervalos entre ensaios. Cada cão foi testado em duas sessões diferentes (com intervalo de duas semanas), com duração aproximada de uma hora para cada. Dividimos os animais em dois grupos: o "grupo cão" $(\mathrm{N}=8)$ que foi apresentado aos estímulos caninos na primeira sessão e aos humanos na segunda sessão e o "grupo humano" $(\mathrm{N}=9)$ que foi apresentado primeiro aos estímulos humanos: todos os cães viram todas as imagens e ouviram todas as vocalizações de indivíduos de ambos os sexos das suas espécies.

Para diminuir o efeito de habituação ao paradigma foram utilizadas duas estratégias: o menor número possível de ensaios em cada sessão (suficiente para responder as perguntas da pesquisa) e um grupo de estímulos inteiramente novo ao participante na segunda sessão experimental. $\mathrm{O}$ anexo $\mathrm{B}$ mostra as combinações de estímulos caninos e humanos aos quais os sujeitos foram expostos.

O lado da apresentação para cada expressão facial em cada combinação foi balanceada dentre sujeitos para que aparecesse o mesmo número de vezes de cada lado (esquerda e 
direita) para cada cão. Cada par de imagens ocorreu duas vezes sempre com um som (congruente a uma das faces): cada som foi apresentado com as mesmas figuras duas vezes (a mesma vocalização foi usada para pares equivalentes de estímulos). Para cada cão a ordem de apresentação das combinações foi semi-aleatorizada, controlando para não mais do que dois ensaios do mesmo sexo (indivíduo) em sequência (quadrados latinos e aleatorização em blocos). Também foram usados dois ensaios controles que diferiram dos ensaios teste por serem pareados com um som neutro ( $\mathrm{SN}$; ruído marrom), para testar se o reconhecimento cross-modal estava acontecendo pelo conteúdo emocional das vocalizações ao invés de qualquer outra característica acústica - o lado de apresentação de cada imagem nos ensaios controle foi contrabalanceado entre sujeitos.

Para controlar o fato de que algumas fotografias não foram tiradas com ângulo absolutamente frontal, ambos os grupos foram divididos em dois subgrupos e cada um viu estímulos diferentes: imagens originais $(\mathrm{N}=8)$ e imagens espelhadas $(\mathrm{N}=9)$.

Todos os cães foram testados em todas as combinações (desenho experimental dentresujeitos: cada animal funciona como seu próprio controle para variabilidade), totalizando 20 ensaios (10 para a primeira sessão e 10 para a segunda sessão) por cão mais as re-tentativas (no caso de um ensaio não ter sido completado por qualquer motivo).

\subsection{Procedimentos}

Os experimentos foram realizados em uma sala experimental (fig. 3 e 4) silenciosa com iluminação reduzida (durante os testes as luzes era desligadas para uma melhor apresentação do estímulo), por duas experimentadoras (E1 e E2). Durante os testes, o tutor não estava presente e nenhum reforço era dado ao cão. Além disso, não houve qualquer treinamento prévio às sessões. 


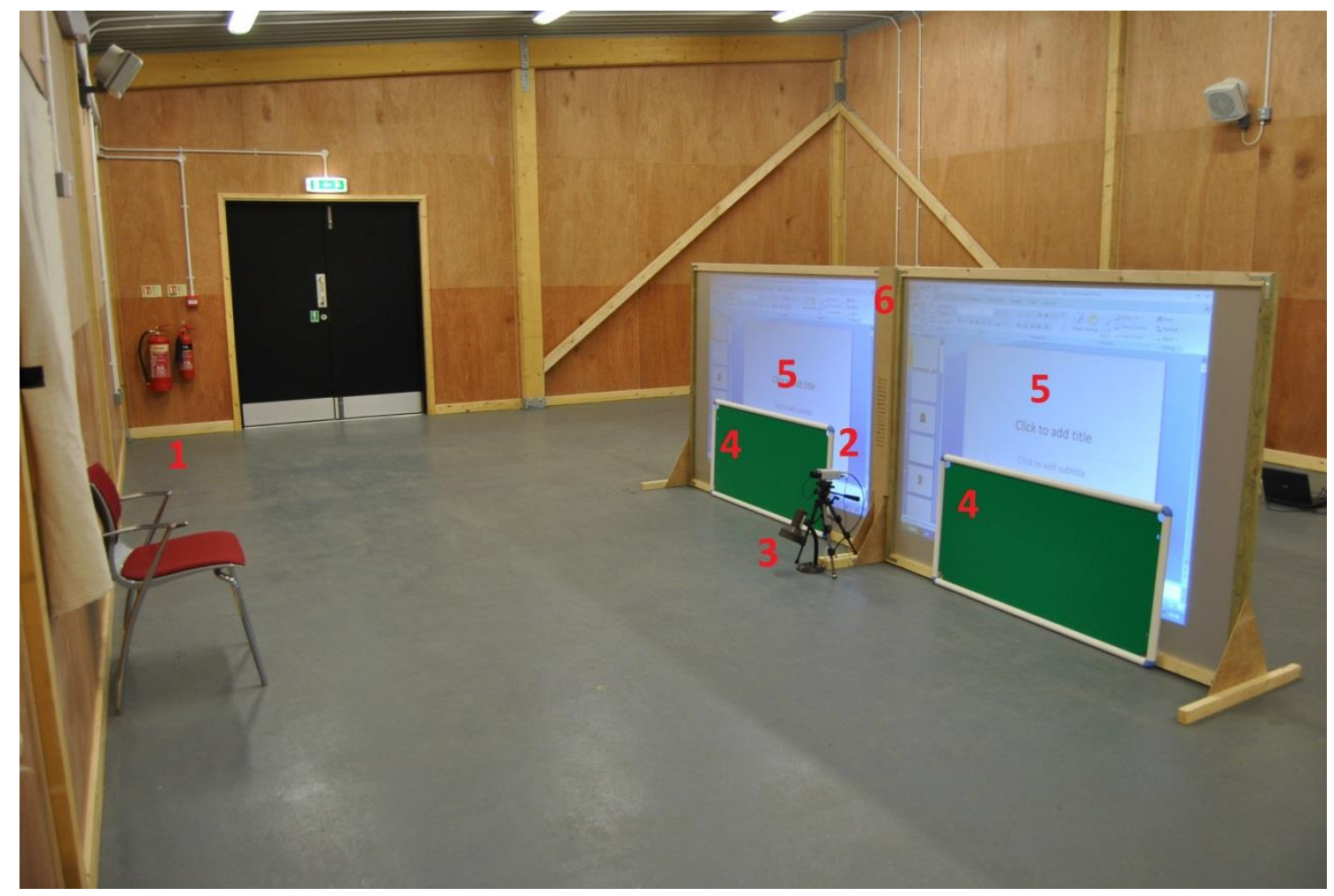

Figura 3. Set up experimental (antes do teste). 1) cadeira para E2; 2) camera CCTV; 3) luminária; 4) barreiras; 5) telas; 6) painel com luzes que piscavam.

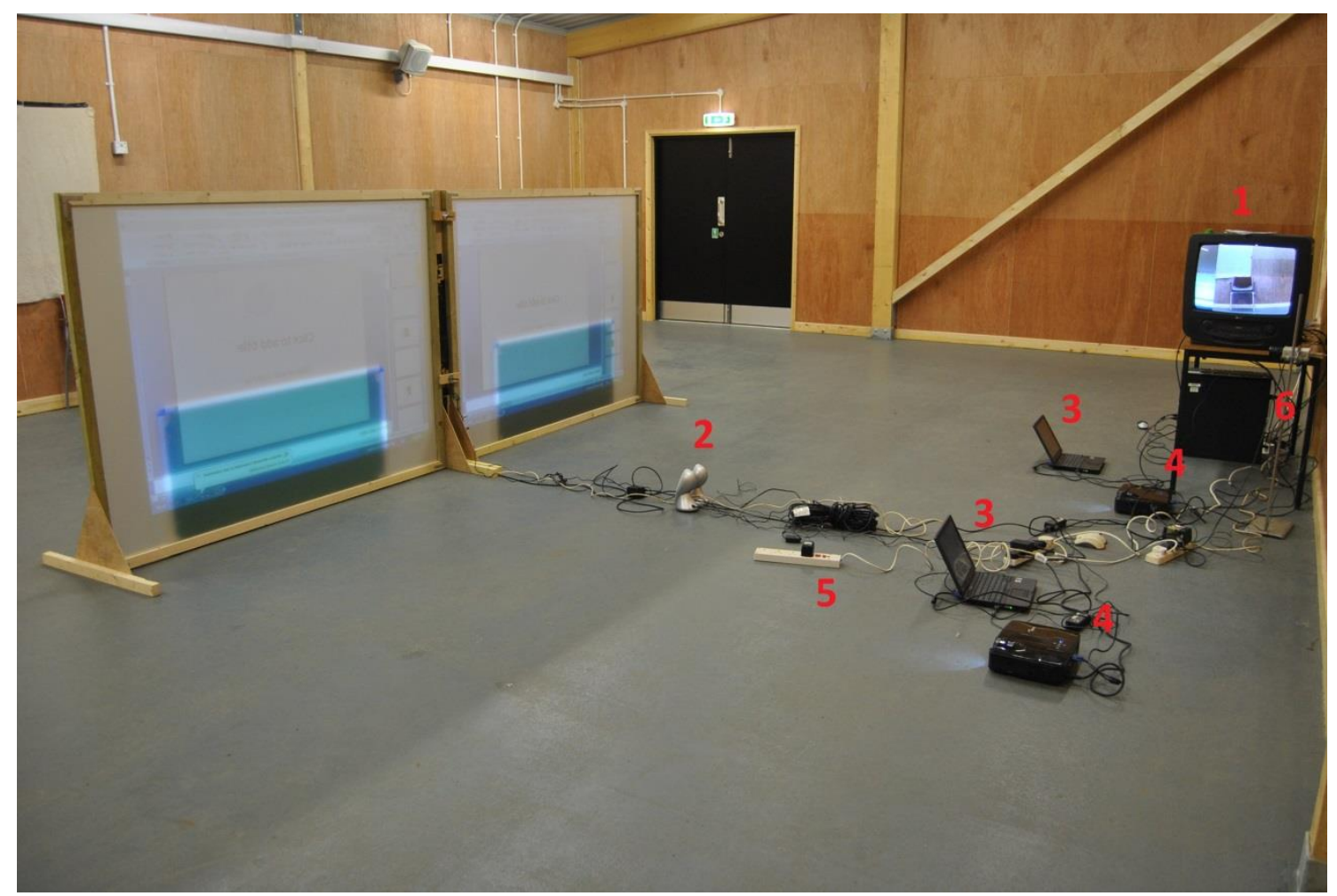

Figura 4. Set up experimental (antes do teste). 1) monitor; 2) alto-falantes; 3) computadores;

4) projetores; 5) interruptor para controlar as luzes do painel; 6) segunda câmera. 
Previamente, os tutores eram instruídos sobre as linhas gerais da pesquisa. No dia da coleta de dados, antes dos testes começarem, cão e responsável entravam na sala experimental para que o cão pudesse explorar o novo ambiente e se habituar. Enquanto isso, E1 explicava os procedimentos para o tutor (cerca de cinco minutos). O tutor, então, saía para uma área adjacente à sala experimental. E1, então, posicionava a câmera e dava zoom na face do sujeito e começava a gravação. Depois, E1 ia para trás das telas, onde ficava durante os testes.

Uma cadeira para E2 era colocada no fundo da sala experimental (de frente para as telas; $285 \mathrm{~cm}$ distante delas) e o cão permanecia exatamente à sua frente (sentado ou deitado), entre suas pernas (fig. 5). Os cães não ficavam na guia e E2 os posicionava antes do ensaio começar. Para controlar qualquer possível interferência na resposta comportamental do sujeito, E2 não interagia com o cão em nenhuma situação durante os testes; olhava para baixo e usava fones de ouvido pelos quais escutava música que bloqueava o estímulo acústico.

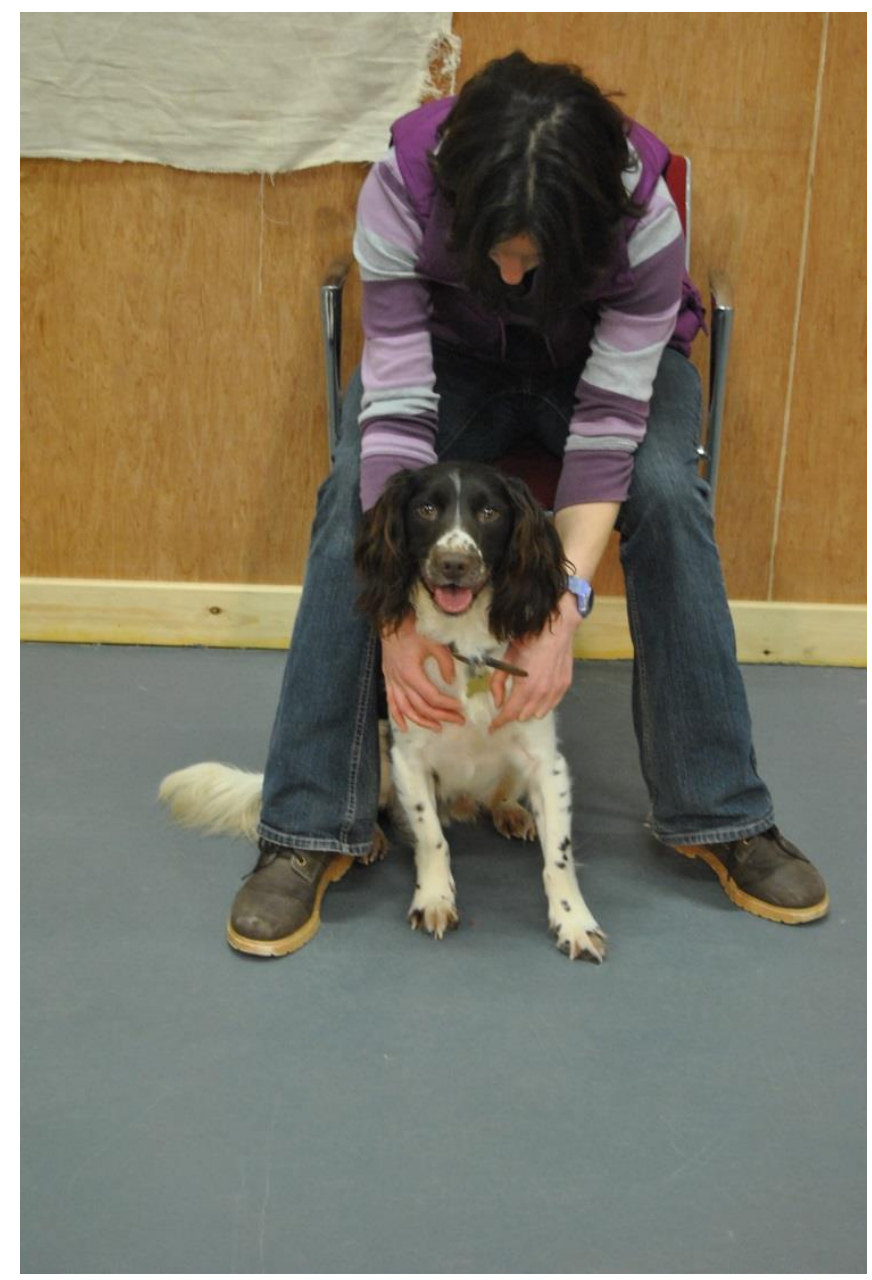

Figura 5. Exemplo de posição de cão sentado entre as pernas de E2. 
Os sujeitos permaneceram em frente às duas telas nas quais os estímulos visuais foram projetados, $220 \mathrm{~cm}$ distantes delas. Dois alto-falantes (JBL Duet) foram colocados no chão, atrás das telas (uma no meio de cada; $140 \mathrm{~cm}$ de distância) - a intensidade média do conjunto de estímulos sonoros caninos foi igual a $57,6 \mathrm{~dB}$ e a intensidade média do conjunto de estímulos sonoros humanos foi igual a $54,7 \mathrm{~dB}$. Todos os cães ficaram posicionados no meio das duas telas durantes todos os ensaios. Uma câmera CCTV (Sanyo CCD, VVC-3312P) ficava posicionada em frente ao cão, no meio das duas câmeras e foi usada para monitorar e registrar o comportamento visual dos sujeitos (movimento dos olhos e da cabeça), além de outros comportamentos observáveis (sentar, levantar, deitar, procurar por E2, lamber a boca, ofegar, mover-se para longe do estímulo) - logo em frente estava posicionava uma luminária para ajudar no processo de codificação. Uma segunda câmera digital (Sanyo CCD, VVC3312P) foi utilizada para monitorar a apresentação e ficava sempre direcionada à tela 2. E1 chamava a atenção do cão e controlava a apresentação de estímulos (computadores conectados a projetores) de trás das telas, além de monitorar os eventos em tempo real (via câmera CCTV) - o sujeito não conseguia ver E1 durante os testes. Um monitor era ligado às câmeras, o que permitia que E1 observasse tanto a atenção e o comportamento do cão quanto a projeção de imagens nas telas.

As imagens foram apresentadas por dois projetores idênticos (Optoma EX551) que foram posicionadas atrás de cada uma das telas, a $307 \mathrm{~cm}$. Uma sequência de 21 slides (MS Power-Point 2010) foi usada para apresentação dos estímulos: antes da projeção da combinação de estímulos sempre havia uma tela homogênea cinza clara sem imagem e o painel de luzes estava ligado neste momento até que a atenção dos cães estivesse voltada para ele; se as luzes não eram suficientes, E1 usava alguns sons mecânicos (e.g. bater na parede e soltar uma caneta do chão). Uma vez que o olhar do cão estava direcionado para o centro, o estímulo era apresentado (uma imagem em cada tela e um som emitido automaticamente quando as fotografias apareciam) e o cão podia olhar para onde desejasse (fig. 6). 


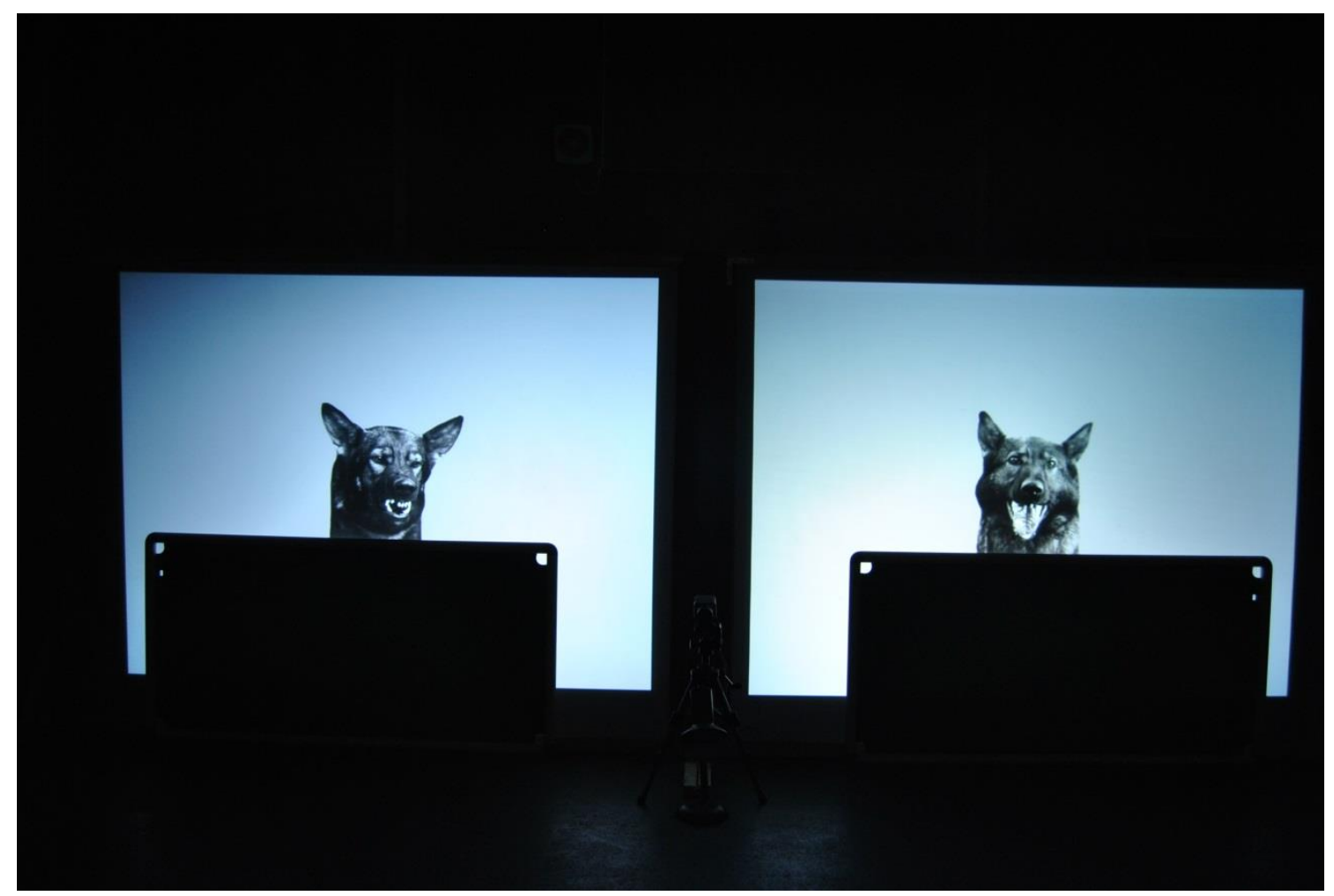

Figura 6. Exemplo de apresentação de estímulos: duas imagens do mesmo indivíduo exibindo diferentes expressões faciais (o som tocava durante o ensaio inteiro).

Ao final da apresentação de todos os estímulos, uma tela preta homogênea aparecia marcando o término dos testes. A passagem dos slides era controlada por E1 através de um dispositivo criado para este experimento a partir de dois mouses (fig. 7) e era dependente da atenção do sujeito. A mudança do slide com estímulo para a próxima tela cinza acontecia automaticamente após o período de cinco segundos. Assim que o slide final aparecia, o teste era finalizado e a experimentadora desligava a câmera e acendia as luzes. 


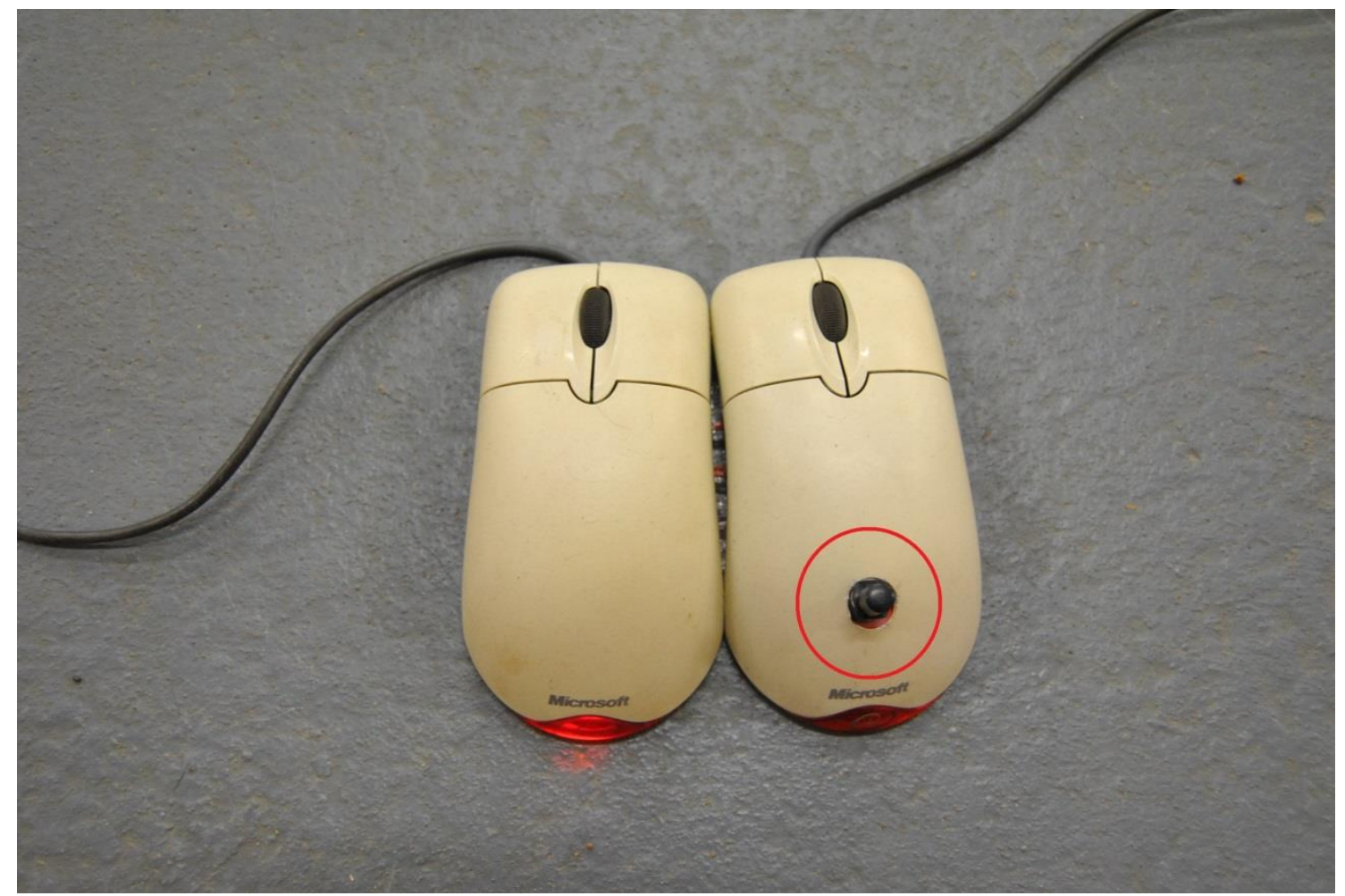

Figura 7. Dis positivo utilizado para controlar ambos computadores ao mesmo tepo. Ao clicar no botão (dentro do círculo vermelho) as apresentações seriam ativadas simultaneamente.

Para manter os participantes motivados, intervalos (entre 2 e 10 minutos cada, dependendo da falta de atenção do sujeito) entre os testes além petiscos para cães durante os intervalos e na fase de habituação (nunca durante os testes). Se o cão parasse de olhar para os estímulos no meio da apresentação, cabia à experimentadora julgar a necessidade de refazer aquele ensaio. Se este fosse o caso, o ensaio era repetido ao final da sessão de teste. Para cada cão, cada sessão (cão e humano) era constituída de 10 ensaios testes mais as repetições: uma mesma combinação poderia ser repetida até duas vezes nas sessões experimentais. Apenas uma de cada combinação foi utilizada para as análises, portanto, foi feita uma seleção entre testes e re-tentativas. Para escolher quais ensaios eram mais adequados, foram utilizados dois critérios: 1) o ensaios do grupo teste (10 primeiros) tinham prioridade sobre as re-tentativas (qualquer efeito de habituação seria mais fraco no início da sessão) e 2) os ensaios com maior tempo de olhar para as telas. 


\subsection{Codificação e análises comportamentais}

Os vídeos foram convertidos em arquivos avi e a codificação foi feita por E1 cega à combinação de estímulos, em ordem aleatória. Todos os registros foram codificados com o programa Solomon Coder beta, no qual foi possível usar duas velocidades para as análises do comportamento visual: velocidade normal para observar comportamentos mais evidentes e análise quadro-a-quadro $(0,02 \mathrm{~s})$ para codificar o movimento dos olhos e da cabeça de forma detalhada.

Um ensaio foi considerado bem sucedido quando o sujeito olhou para as telas por pelo menos 2,5 segundos. Além disso, só foram considerados para as análises os ensaios em que o cão iniciou o teste direcionado para o meio das duas telas - de onde era possível ver com clareza que havia duas imagens. Em algumas situações, o sujeito passou boa parte do tempo olhando para o centro, mas tendo havido pelo menos uma fixação nas figuras o ensaio foi considerado. Todos os cães utilizados nas análises atingiram o critério de um mínimo de $70 \%$ de resposta ao paradigma.

A direção do olhar foi medida pela mudança na posição da pupila e/ou da esclera visível em cada lado da íris (Racca et al., 2010) e categorizadas em "centro", "direita do cão", "esquerda do cão" e "fora" (fig. 8). Além da direção do olhar, o movimento da cabeça também foi utilizado na codificação. No entanto, o movimento dos olhos sempre teve prioridade na codificação do comportamento visual. Porque os cães se encontravam distantes das telas, o movimento dos olhos e da cabeça era geralmente bastante claro.

O comportamento de olhar (e a preferência visual) dos cães foi registrado e codificado durante os cinco segundos de cada sessão teste. Direção do olhar (direita, esquerda, centro e fora), duração total (direita + esquerda + centro) e duração do olhar para cada uma das telas foram medidas. Uma segunda codificadora (E2), também cega às combinações de estímulos, analisou $15 \%$ dos vídeos e o grau de concordância entre observadores foi testado usando Correlação de Pearson: r=0,861 e p<0,0001 para índice de congruência; $r=0,982$ e p<0,0001 para tempo de olhar total. 

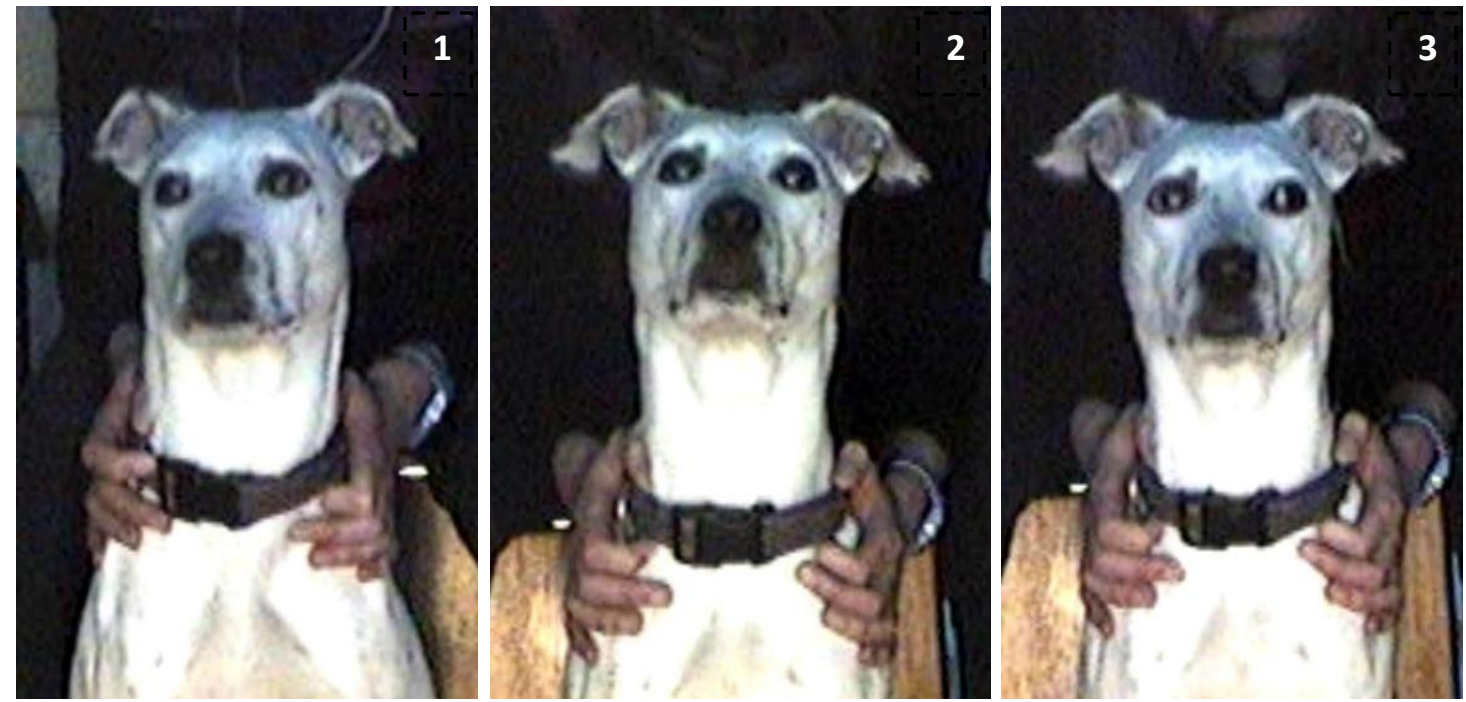

Figura 8. Sujeito em teste: 1) olhando para tela a sua direita; 2) olhando para o centro; 3) olhando para tela a sua esquerda.

\subsection{Análises estatísticas}

A habilidade de reconhecer emoções de maneira cross-modal foi medida por meio de um índice de congruência (IC) obtido das condições de teste. Este índice foi medido a partir do tempo de olhada para cada uma das imagens (congruente ao som ou incongruente ao som) e o tempo de olhada total em direção às telas em cada ensaio: $\mathrm{IC}=\frac{C-I}{T}$, onde $\mathrm{C}$ é o tempo de olhada para a imagem congruente, I o tempo de olhada para a imagem incongruente e $\mathrm{T}$ o tempo de olhada total $(\mathrm{C}+\mathrm{I}+\mathrm{C}$ entro $)$. Os índices de valores maiores que zero indicam que houve a associação entre o conteúdo do som e o da imagem ( matching $^{3}$ ), enquanto os índices de valores menores ou iguais a zero indicam que o reconhecimento da emoção não foi feito. $\mathrm{O}$ número de ensaios teste foi 188 .

O índice de congruência foi utilizado para as análises de matching no conjunto de ensaios e na investigação de possíveis efeitos dos quatro fatores principais: espécie (cão e ser humano); sexo (feminino e masculino); valência do estímulo congruente (negativa e positiva) e lado de apresentação do estímulo visual (esquerda do cão e direita do cão).

Para verificar se a resposta dos cães aos estímulos foi um reflexo do reconhecimento da informação emocional das vocalizações e não estava ligada somente à discriminação de características físicas dos sons, os sujeitos foram avaliados em condições controle, nas quais

\footnotetext{
${ }^{3}$ Matching é o termo em inglês para o comportamento de olhar por mais tempo para a imagem congruente ao som.
} 
as duas imagens foram pareadas com um som neutro. Nestes ensaios, não havia imagem congruente ou incongruente, por isso utilizamos outro índice (I): $\mathrm{I}=\frac{E-D}{T}$, onde E é o tempo de olhada para a tela esquerda, D o tempo de olhada para tela direita e T o tempo de olhada total (E+D+Centro). Índices com valores maiores que zero indicaram preferência pela tela esquerda; índices menores que zero indicaram preferência pela tela direita e índices iguais a zero indicaram que não houve preferência por uma ou outra tela (tempo de olhada igual para as duas). O número de ensaios controle foi 51.

Para verificar se os cães preferiram as faces de valência positiva em relação às de valência negativa - uma resposta comportamental possível seria a dos sujeitos evitarem a expressões faciais de raiva e agressividade - comparamos as respostas para os dois tipos. Nesse sentido, todos os ensaios (testes + controles) foram avaliados e, para isso, utilizamos um índice de preferência (IP): IP $=\frac{P-N}{T}$, onde $\mathrm{P}$ é o tempo de olhada para a imagem positiva, $\mathrm{N}$ é o tempo de olhada para a imagem negativa e $\mathrm{T}$ o tempo de olhada total $(\mathrm{P}+\mathrm{N}+\mathrm{Centro})$. Índices com valores maiores que zero indicaram preferência pela imagem positiva; índices menores que zero indicaram preferência pela imagem negativa e índices iguais a zero indicaram que não houve preferência por uma ou outra valência (tempo de olhada igual para as duas imagens). O número total de ensaios foi 239.

Todas as análises foram realizadas com o programa SAS 9.2 (SAS Institute Inc., EUA) e o nível de significância considerado foi de $5 \%$. Os dados foram inicialmente resumidos em média e erro padrão.

Para verificar a ocorrência do matching foi utilizada uma análise descritiva (conjunto de ensaios e ensaios separados por fator: espécie; sexo; valência e lado) e um teste t de student (para uma média), que comparou a média dos índices de congruência com zero.

Para avaliar os possíveis efeitos, uma análise de variância foi escolhida. Inicialmente, procuramos verificar a dependência das observações feitas do mesmo indivíduo por meio do modelo linear misto (GLMM; General Linear Mixed Model). Entretanto, essa dependência não foi significativa. Foi adotado, portanto, um modelo de independência: o modelo linear (GLM; General Linear Model). Os quatro fatores principais e suas interações de $1^{\mathrm{a}}$ e $2^{\mathrm{a}}$ ordem foram considerados no modelo inicial e "espécie" foi o único efeito encontrado. Foi feita, então, uma seleção de variáveis pelo método backwards e somente o fator "espécie" foi significativo e selecionado para o modelo final.

A suposição de normalidade do modelo foi verificada por meio de uma análise de resíduos. Nenhum desvio importante do normal foi identificado. 
Para verificar uma possível interação entre o sexo do sujeito e do estímulo na qualidade da percepção das informações emocionais provindas das vocalizações e das expressões faciais (medida por meio do índice de congruência), foi utilizado um modelo de análise de variância (GLM) inicial considerando os dois fatores (sexo do cão e sexo do estímulo).

Para avaliar se a resposta (média dos índices) dos cães para cada tipo de estímulo foi maior do que zero, foram utilizados testes t de student para uma média.

As condições controle também foram analisadas e, para verificar se não houve diferença significativa entre o tempo alocado para uma ou outra imagem, foi utilizado um teste $\mathrm{t}$ de student para uma média. Além disso, o teste $\mathrm{t}$ de student também foi usado para avaliar uma possível preferência pelas imagens de valência positiva, em relação às negativas.

Finalmente, para avaliar se o tipo do estímulo e o grupo exerceram algum tipo de influência sobre a resposta visual dos cães testados, foram usados testes $\mathrm{t}$ de student para duas médias para comparar os índices de congruência entre "grupo cão" e "grupo humano" e entre estímulos originais e estímulos espelhados. Em ambas as comparações, as variâncias foram iguais, tendo sido utilizado, dessa maneira, o método pooled de análise. 
Capítulo 3 - Resultados 


\section{Resultados}

\subsection{Congruência: a ocorrência do matching}

Os cães associaram o conteúdo emocional do som ao da imagem congruente em $66,49 \%$ dos ensaios $(n=188)$. Separamos os dados de resposta dos cães para cada um dos quatro fatores investigados (espécie do estímulo, sexo do estímulo, valência do estímulo congruente e lado de apresentação do estímulo) e um maior tempo de olhar direcionado para a imagem congruente se deu na maioria das vezes, em comparação com o tempo de olhar para a imagem incongruente, para todos. Os gráficos abaixo (fig. 9) mostram a distribuição do matching no conjunto de ensaios: "congruente" representa que os cães olharam por mais tempo para a imagem congruente e "incongruente" refere-se aos ensaios em que os cães passaram mais tempo olhando para a imagem incongruente.

(A)

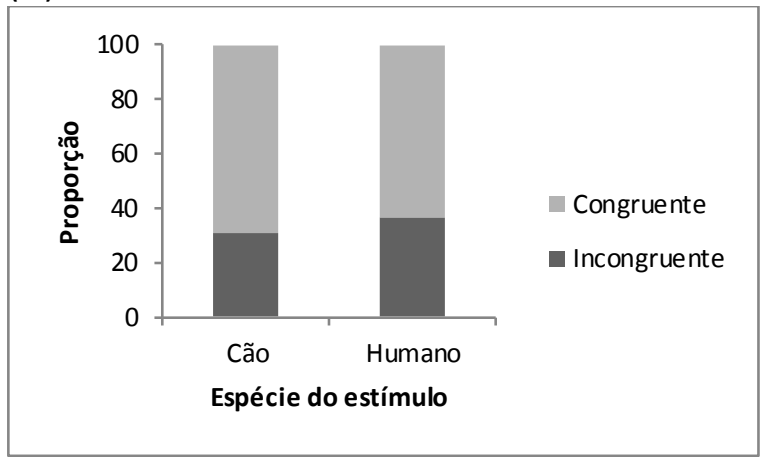

(C)

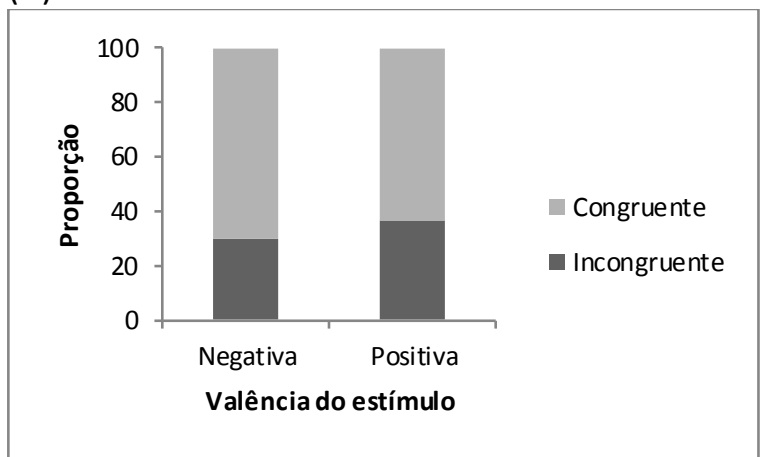

(B)

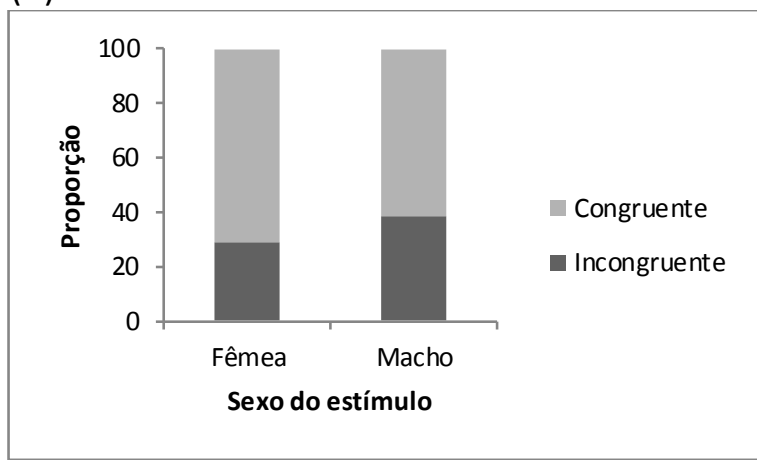

(D)

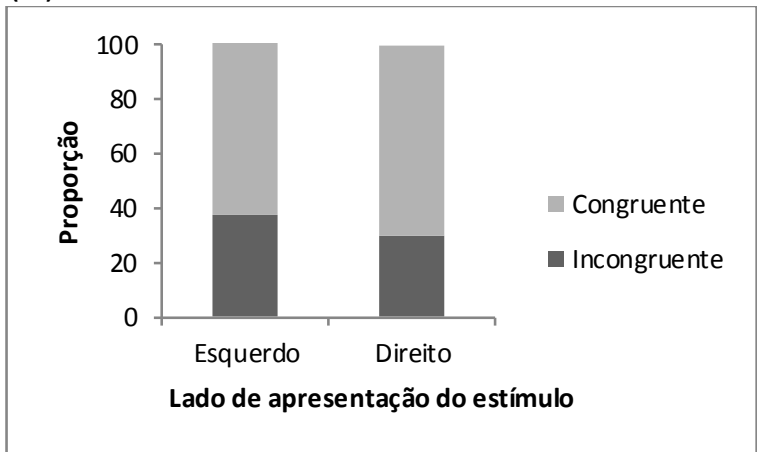

Figura 9. Distribuição da proporção de olhar para o estímulo congruente ou para o estímulo incongruente no conjunto dos ensaios com estímulos: A) caninos e humanos (n=95 para "Cão"; n=93 para "Humano"); B) femininos e masculinos (n=97 para "Fêmea"; n=91 para "Macho"); C) negativos e positivos (n=96 para "Negativa"; $n=92$ para "Positiva") e D) apresentados do lado esquerdo e do lado direito (n=93 para "Esquerdo"; $\mathrm{n}=95$ para "Direito"). 
A média dos índices de congruência foi igual a $0,193( \pm 0,034)$ e significativamente maior do que zero $\left(\mathrm{t}_{187}=5.6 ; \mathrm{p}<0,0001\right)$, o que indica que os cães olharam por mais tempo para a imagem congruente, ao longo dos ensaios.

\subsection{Interações e efeitos}

Partindo do conhecimento de que os cães associaram a informação dos sons à das imagens e que olharam, em média, por mais tempo para as imagens congruentes, investigamos possíveis interações e efeitos dos diferentes estímulos (caninos, humanos, femininos, masculinos, negativos, positivos, apresentados do lado direito do cão e apresentados do lado esquerdo do cão). Uma análise descritiva desses fatores pode ser vista abaixo (tabela 2).

Tabela 2. Análise descritiva da resposta dos cães para cada uma das categorias de estímulo ao longo dos ensaios (testes; n=188 para cada fator).

\begin{tabular}{|ccccc|}
\hline Fator & Categoria & N & Média & Erro \\
\hline Espécie & Cão & 95 & 0,264 & 0,046 \\
& Humano & 93 & 0,120 & 0,050 \\
Sexo & Fêmea & 97 & 0,222 & 0,046 \\
& Macho & 91 & 0,162 & 0,052 \\
Valência & Negativa & 96 & 0,242 & 0,047 \\
& Positiva & 92 & 0,142 & 0,051 \\
Lado & Esquerdo & 93 & 0,137 & 0,048 \\
& Direito & 95 & 0,247 & 0,049 \\
\hline
\end{tabular}

A seleção de variáveis aplicada no modelo de análise de variância, considerando os quatro fatores e as interações, resultou no modelo final que incluiu somente um único efeito: espécie. Os resultados apontam para um efeito significativo de espécie sobre o desempenho dos cães na tarefa de reconhecimento cross-modal de emoções_( $F_{1 ; 186}=4,42 ; p=0,037$; fig. 10$)$. 
Tabela 3. Modelo de variância (GLM) inicial

\begin{tabular}{ccccc}
\hline Efeito & $\begin{array}{c}\text { Graus de } \\
\text { liberdade } \\
\text { (numerador) }\end{array}$ & $\begin{array}{c}\text { Graus de } \\
\text { liberdade } \\
\text { (denominador) }\end{array}$ & $\begin{array}{c}\text { Valor da } \\
\text { estatística F }\end{array}$ & Valor do p \\
\hline sexo & 1 & 174 & 0,26 & 0,609 \\
espécie (spp) & $\underline{1}$ & $\underline{174}$ & $\underline{4,45}$ & $\underline{0,036^{*}}$ \\
valência (val) & 1 & 174 & 1,8 & 0,182 \\
lado & 1 & 174 & 2,85 & 0,093 \\
sexo_spp & 1 & 174 & 1,61 & 0,207 \\
sexo_val & 1 & 174 & 0,04 & 0,835 \\
sexo_lado & 1 & 174 & 3,36 & 0,069 \\
spp_val & 1 & 174 & 0,07 & 0,788 \\
spp_lado & 1 & 174 & 0,03 & 0,858 \\
val_lado & 1 & 174 & 0,14 & 0,706 \\
sexo_spp_val & 1 & 174 & 2,66 & 0,103 \\
sexo_spp_lado & 1 & 174 & 0,69 & 0,406 \\
spp_val_lado & 1 & 174 & 0,01 & 0,919 \\
\hline
\end{tabular}

As análises para avaliar se a resposta (média dos índices) dos cães para as diferentes categorias foi maior do que zero revelaram resultados significativos para todos os tipos de estímulo. Os gráficos abaixo são representações desses achados.

A figura 10 mostra o efeito de espécie (maior desempenho para estímulos caninos do que para humanos). Além disso, é possível observar que em média os índices foram significativamente maiores do que zero tanto para estímulos caninos quanto para humanos (“Cão": t ${ }_{94}=5.731$ e p $<0.0001$; "Humano": $t_{92}=2.384$ e p=0.019).

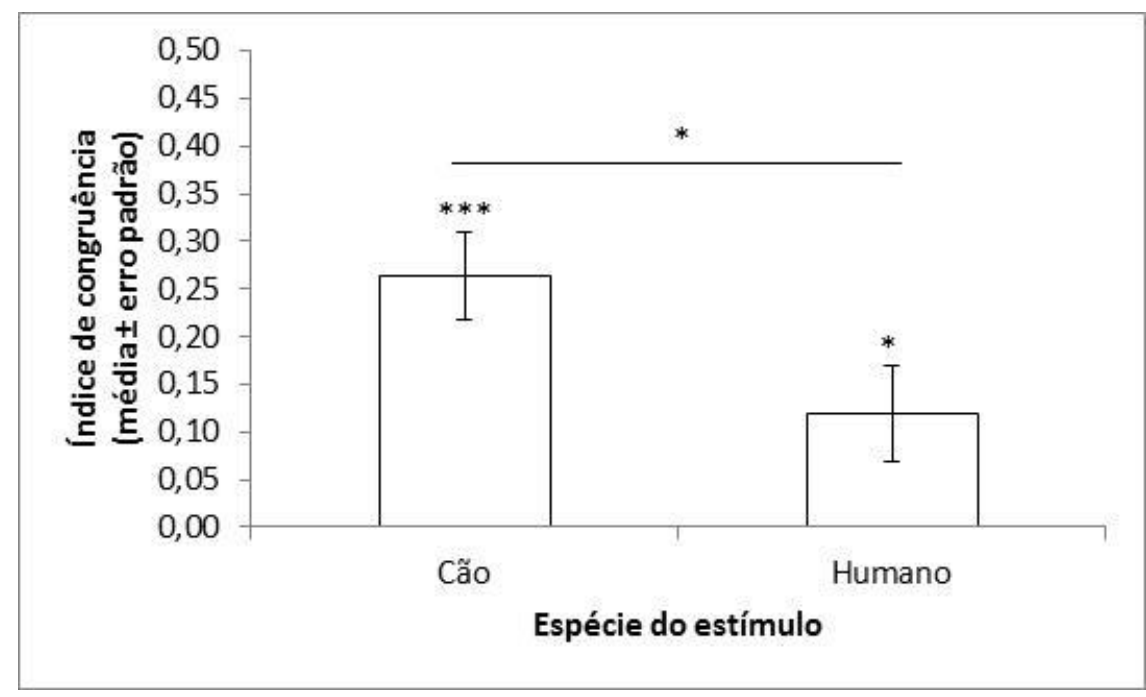

Figura 10. Resposta dos cães para ensaios comestímulos caninos e ensaios com estímulos humanos. Acima de cada barra encontra-se o resultado do teste estatístico que avaliou se a resposta era significativamente maior do que zero. A linha acima das barras representa o efeito de espécie $\left(\mathrm{f}_{1 ; 186}=4,42 ; \mathrm{p}=0,037\right)$. 
Observou-se, também, que em média os índices foram significativamente maiores do que zero para estímulos femininos e para estímulos masculinos. As análises revelaram $\mathrm{t}_{96}=4.829$ e $\mathrm{p}<0.0001$ para "Fêmea" e $\mathrm{t}_{90}=3.137$ e $\mathrm{p}=0.002$ para "Macho" (fig. 11) .

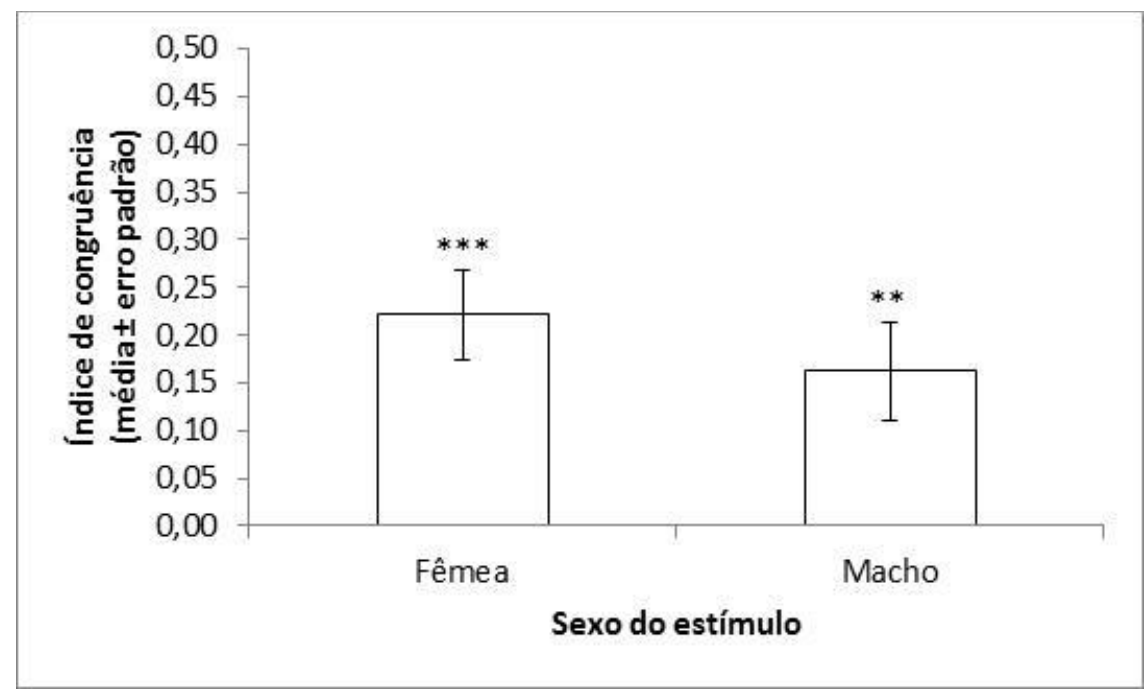

Figura 11. Resposta dos cães para ensaios com estímulos femininos e ensaios com estímulos masculinos. Acima de cada barra encontra-se o resultado do teste estatístico que avaliou se a resposta era significativamente maior do que zero.

Quanto à categoria "valência do estímulo", foi encontrado que em média os índices foram significativamente maiores do que zero para estímulos negativos e para positivos, sendo $t_{95}=5.188$ e $p<0.0001$ para "Negativa" e $t_{91}=2.804$ e $p=0.006$ para "Positiva" (fig. 12).

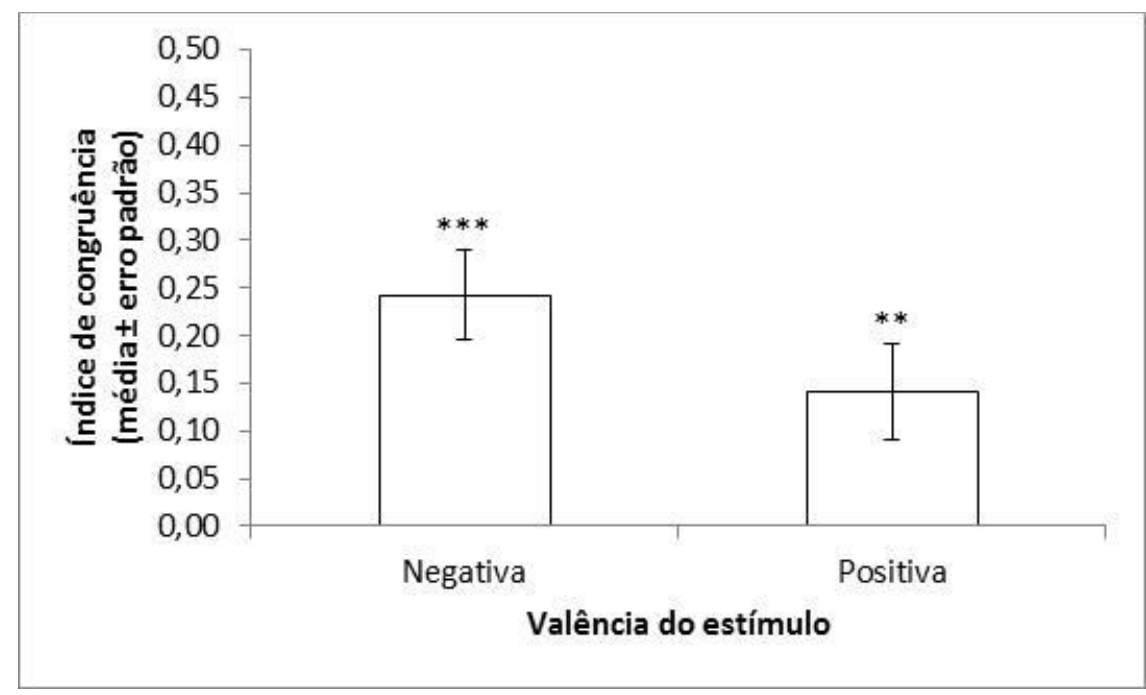

Figura 12. Resposta dos cães para ensaios comestímulos congruentes negativos e ensaios com estímulos congruentes positivos. Acima de cada barra encontra-se o resultado do teste estatístico que avaliou se a resposta era significativamente maior do que zero. 
Finalmente, na figura 13 é possível perceber que para a categoria "lado de apresentação do estímulo" os índices foram em média significativamente maiores do que zero, tanto para estímulos apresentados na esquerda do sujeito e estímulos apresentados na direita ("Esquerdo": $\mathrm{t}_{92}=5.026$ e $\mathrm{p}<0.0001$; "Direito": $\mathrm{t}_{94}=2.876$ e $\mathrm{p}=0.005$ ).

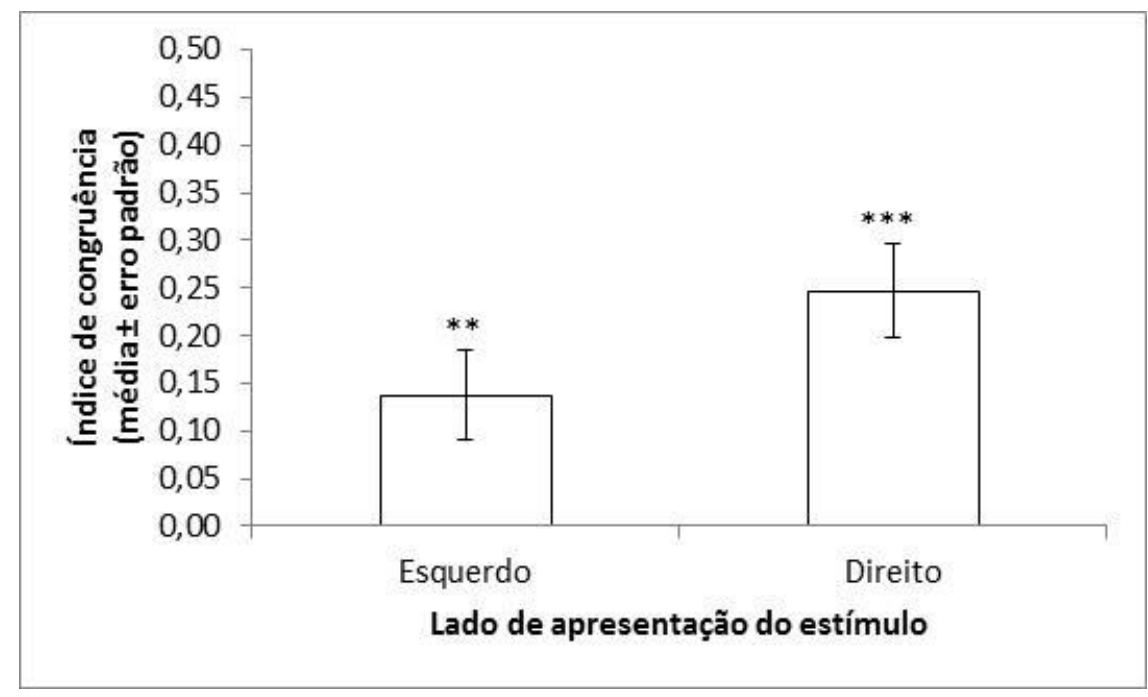

Figura 13. Resposta dos cães para ensaios com estímulos apresentados do lado esquerdo e ensaios com estímulos apresentados do lado direito. Acima de cada barra encontra-se o resultado do teste estatístico que avaliou se a resposta era significativamente maior do que zero.

\subsection{Interação entre sexos}

Uma possível interação entre o sexo do sujeito e o sexo do estímulo e o efeito principal do sexo do sujeito sobre as respostas dos cães na tarefa de reconhecimento crossmodal de emoções foram investigadas. No entanto, nenhum efeito foi encontrado (tabela 3; fig. 14).

Tabela 4. Modelo de variância (GLM) - nenhum efeito foi encontrado.

\begin{tabular}{ccccc}
\hline Efeito & $\begin{array}{c}\text { Graus de } \\
\text { liberdade } \\
\text { (numerador) }\end{array}$ & $\begin{array}{c}\text { Graus de } \\
\text { liberdade } \\
\text { (denominador) }\end{array}$ & $\begin{array}{c}\text { Valor da } \\
\text { estatística } \\
\text { F }\end{array}$ & $\begin{array}{c}\text { Valor do } \\
\mathbf{p}\end{array}$ \\
\hline Sexo do sujeito (Sex_suj) & 1 & 184 & 0,17 & 0,684 \\
Sexo do estímulo (Sex_est) & 1 & 184 & 0,58 & 0,448 \\
Sex_suj*Sex_est & 1 & 184 & 1,27 & 0,261 \\
\hline
\end{tabular}


Como o efeito de interação não foi significativo, assim como os efeitos principais, as curvas na figura 14 não são significativamente diferentes. Embora o gráfico apresente um cruzamento das curvas, os resultados não foram significativos, o que significa que o sexo do sujeito e o sexo do estímulo não exerceram qualquer influência no desempenho dos cães testados neste estudo.

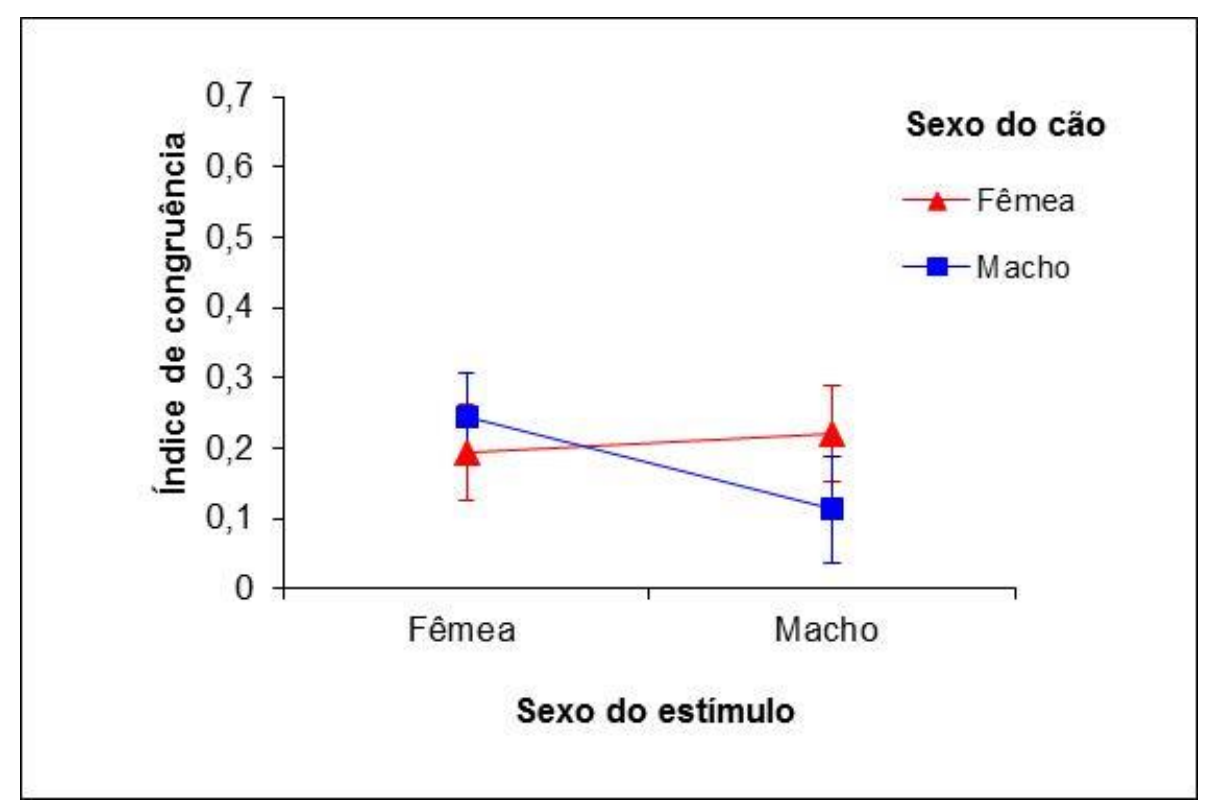

Figura 14. Média e erro padrão das respostas para cada combinação entre sexo do sujeito e sexo do estímulo. Cão fêmea-estímulo feminino: n=44; Cão fêmeaestímulo masculino: $n=42$; Cão macho-estímulo feminino: $n=53$; Cão machoestímulo masculino: $n=49$.

\subsection{Controles e preferência}

Para as condições controle, a média dos índices foi igual a $0.038( \pm 0.068)$, que não é significativamente maior do que zero $\left(\mathrm{t}_{50}=0.56 ; \mathrm{p}=0.578\right)$. Isto indica que o tempo de olhada para cada uma das telas foi semelhante, não tendo havido tendência por um ou outro tipo de estímulo.

Em relação a uma possível preferência por uma das valências emocionais, a média do índice de preferência foi igual a $-0.052( \pm 0.032)$, que não é significativamente maior que zero $\left(\mathrm{t}_{238}=-1.6 ; \mathrm{p}=0.111\right)$. O tempo de olhada para cada um dos tipos de expressões faciais (positivas e negativas) foi semelhante, o que indica que os cães não preferiram ou evitaram nenhuma das duas. 


\subsection{Tipo de estímulo e grupo}

Foi verificado que não houve diferença significativa no desempenho dos sujeitos do "grupo cão" em comparação com o desempenho dos sujeitos do "grupo humano", ou seja, o grupo não influenciou a resposta dos cães $\left(\mathrm{t}_{186}=-1.31 \mathrm{e} \mathrm{p}=0.193\right)$. Além disso, também foi verifcado que não houve diferença significativa entre as respostas dos sujeitos quando expostos a estímulos originais em comparação com as respostas dos sujeitos quando expostos a estímulos espelhados. Isto quer dizer que não houve influência do tipo do estímulo no comportamento visual dos animais testados neste paradigma de preferência de olhar $\left(\mathrm{t}_{186}=0.88\right.$ e $\mathrm{p}=0.378)$. 
Capítulo 4 - Discussão 


\section{Discussão}

Cães possuem a habilidade de criar uma representação cognitiva do sinalizador ou do sinal depois de terem sido expostos a um estímulo e de integrar características fornecidas por modalidades perceptuais diferentes (Adachi et al., 2007; Faragó et al., 2010a; Taylor et al., 2011). Além disso, já existem evidências de que cães domésticos processam visualmente faces humanas e de outros cães (Guo et al., 2009; Racca et al., 2010) e de outros cães e de que são sensíveis a pistas emocionais de seres humanos (Morisaki et al., 2009; Deputte \& Doll, 2011; Ruffman \& Morris-Trainor, 2011; Nagasawa et al., 2011; Custance \& Mayer, 2012; Racca et al., 2012; Buttelmann \& Tomasello, 2013). Taylor et al. (2011) sugerem que a integração de pistas sensoriais de maneira cross-modal pode ser funcional para vários tipos de informação. Partindo deste pressuposto, o presente trabalho se propôs a investigar a habilidade de reconhecimento cross-modal em um aspecto crucial para o estabelecimento e a manutenção de relacionamentos sociais tanto intra quanto interespecíficos: a percepção de emoções.

O presente estudo fornece evidências de que cães domésticos possuem a habilidade de obter e utilizar informações de estímulos emocionais de duas modalidades sensoriais distintas e de que são capazes de integrar essas informações numa única representação mental, que vai ser utilizada nos processos de discriminação e reconhecimento. Este é o primeiro trabalho que acessa o reconhecimento cross-modal de emoções de coespecíficos e heteroespecíficos em cães. O objetivo central deste trabalho foi testar a hipótese de que cães possuem a habilidade de associar uma emoção específica expressa por meio de uma vocalização com uma expressão facial de conteúdo congruente ao do estímulo auditivo, ou seja, os sujeitos cães foram avaliados pela sua capacidade de reconhecer emoções cross-modalmente.

Quatro fatores principais foram analisados a partir das respostas apresentadas pelos cães frente aos estímulos emocionais: espécie; sexo; valência do estímulo congruente e lado de apresentação. Esses fatores (e as interações de primeira e segunda ordem) foram levados em consideração na investigação de possíveis efeitos sobre o desempenho dos sujeitos. Além disso, foi investigada a possível interação entre sexo do sujeito e sexo do estímulo. A medida utilizada sempre foi o índice de congruência (proporção do tempo de olhar direcionado para a imagem congruente em relação ao tempo total do comportamento de olhar para as telas) apresentado por cada cão em cada um dos ensaios. 


\subsection{Reconhecimento cross-modal de emoções}

Os resultados do presente estudo mostraram que cães, na maioria das vezes $(66,49 \%)$, associaram a informação emocional da vocalização com a informação emocional da face. Além disso, no conjunto de estímulos, olharam significativamente mais (durante mais tempo) para a imagem congruente, em comparação ao tempo alocado para a imagem incongruente, quando ouvindo o som. Este resultado também é válido quando separados os quatro fatores principais e as oito categorias (espécie: cão e humano; sexo: fêmea e macho; valência: negativa e positiva; lado de apresentação: esquerda e direita). Em todos os casos, os cães fizeram o matching na maioria das vezes e o tempo de olhar médio para cada tipo de estímulo foi significativamente maior do que zero. Isto significa que os sujeitos foram capazes de associar ativamente o conteúdo emocional dos sons ao das expressões faciais exibidas. Os resultados sugerem que, ao ouvir uma determinada vocalização, o cão ativou uma representação mental multimodal da emoção sendo expressa, o que o permitiu perceber uma das faces como congruente e fazer a associação.

Até onde sabemos, os estudos desse tipo com animais não humanos foram realizados com alguns primatas e tiveram como foco a emissão de um sinal sonoro (vocalização) relacionada com a exibição de uma configuração facial particular correspondente. A percepção da fala humana pode ser realçada pela combinação de sinais visuais e auditivos. Animais não humanos também acompanham muitas vezes suas vocalizações com posturas corporais e expressões faciais distintas.

Ghazanfar e Logothetis (2003) também utilizaram um paradigma de preferência de olhar e investigaram a capacidade de macacos rhesus reconhecerem a correspondência entre componentes visuais e auditivos de seus chamados mais frequentes. Encontraram resultados similares aos observados com nossos cães quanto à capacidade de reconhecimento crossmodal de expressões faciais de coespecíficos (apenas testaram os animais com estímulos de outros macacos rhesus): uma porcentagem de tempo de olhar direcionado ao vídeo congruente igual a $67,3 \%$ e significativamente maior do que o esperado se os animais estivessem respondendo ao acaso. Em 2004, Parr e colaboradores estudaram a mesma habilidade em chimpanzés e seus resultados corroboram os achados com macacos rhesus e suportam a ideia de que chimpanzés são capazes de discriminar expressões faciais. Os sujeitos foram capazes de categorizar vídeos de expressões faciais que continham pistas visuais e auditivas congruentes e quando foi apresentada apenas informação de um canal. 
Também em 2004, Izumi e Kojima observaram que uma chimpanzé adulta (Pan) era capaz de associar diferentes vocalizações de outros chimpanzés a expressões faciais correspondentes. Vários estudos foram realizados tendo Pan como sujeito de investigação do processamento auditivo-visual de informações espécie-específicas (e.g. Kojima et al., 2003; Martinez \& Matsuzawa, 2009). No entanto, Pan, além de ter participado de vários estudos cognitivos, passou por um extenso treinamento para tarefas de matching. Dessa maneira, os resultados perdem força devido à dificuldade de extrapolação. Isto leva à questão da importância de se realizar trabalhos que avaliem o comportamento espontâneo dos sujeitos frente a diversos estímulos para controlar para a possibilidade dos resultados serem reflexo de associações simples, aprendidas nos treinos e replicadas nas situações de teste.

Os cães no presente estudo não passaram por qualquer tipo de treino antes dos testes. Foram avaliadas somente suas respostas (comportamento de olhar) espontâneas quando expostos às diferentes combinações de estímulos. Dessa maneira, os cães estavam sempre livres para olhar para onde queriam e a qualidade de suas respostas nunca foi reforçada. A habilidade de integrar informações cross-modais de maneira espontânea sugere que o animal possui uma representação cognitiva daquele estímulo. No caso deste estudo, essa representação foi da expressão emocional que podia ser percebida através da vocalização e do estímulo visual, o que permitiu que os cães fizessem a associação das duas pistas perceptuais.

O presente estudo fornece as primeiras evidências de que cães domésticos são capazes de extrair informações emocionais de faces e de vocalizações tanto de outros cães quanto de seres humanos, de fêmeas e de machos, de emoções de valência negativa e positiva e de estímulos apresentados na sua esquerda e na sua direita.

Esta habilidade de identificar diferentes emoções de coespecíficos e de heteroespecíficos pode indicar que esses animais possuam um entendimento das interações sociais que não é visível. Foi o que sugeriram Parr et al. (2000) no seu estudo com chimpanzés. Argumentaram que, por exemplo, a capacidade de reconhecer indivíduos através de suas vocalizações seja reflexo de um entendimento do meio em que vivem. $\mathrm{O}$ reconhecimento de emoções através de vocalizações e faces pode ser, então, uma forma de entender melhor as situações e relações sociais e pode dar subsídios para que os animais consigam interagir de forma apropriada com outros indivíduos.

Para entender o que esses resultados significam, é necessário discutir o papel funcional do reconhecimento de emoções e da habilidade de integrar informações de maneira crossmodal. 
O reconhecimento de um estímulo particular ocorre quando um animal ativa associações entre a informação perceptual sendo recebida e a representação previamente formada e armazenada daquele estímulo, ou seja, é necessário que um animal possua experiência com um tipo de estímulo e que possua, em sua memória, uma representação cognitiva do mesmo. Em seres humanos, por exemplo, considera-se que o reconhecimento através de integração de pistas múltiplas ocorre pela formação de representações conceituais complexas (Silwa et al., 2011).

A maioria dos estudos na área da percepção é focada exclusivamente no canal visual ou exclusivamente no canal auditivo e isso é verdade também para trabalhos sobre reconhecimento de emoções. No entanto, é importante considerar ambos os canais perceptivos de forma integrada, uma vez que o processamento do mundo se dá de forma multimodal. Segundo Parr (2004), estudos com várias espécies de animais sugerem que indivíduos respondem a sinais multimodais mais rapidamente, com maior acurácia e a estímulos com menor intensidade, em comparação com sinais unimodais.

Silwa et al. (2011) argumentam que as evidências de integração multimodal de pistas individuais em várias espécies levantam a questão do valor adaptativo desse tipo específico de reconhecimento social durante interações com coespecíficos. Depois do reconhecimento dos indivíduos, o reconhecimento de seus estados emocionais de maneira cross-modal pode ser a tarefa de reconhecimento social mais importante e, talvez, a mais complexa de todas elas, pois envolve a formação de conceitos generalizados sobre as diferentes emoções.

Primatas não humanos podem detectar informações invariáveis através de displays visuais e acústicos de expressões emocionais. A habilidade de percepção multimodal na comunicação desses animais pode representar um precursor evolutivo da habilidade humana de fazer associações multimodais (Ghazannfar \& Logothetis, 2003). Neste contexto, é importante discutir o que a existência dessa habilidade em cães pode significar. Cães domésticos são animais filogeneticamente distantes de pessoas, ou seja, não é possível afirmar que a capacidade nesses animais deve-se ao fato de estarem próximos no caminho evolutivo dos seres humanos. No entanto, cães possuem a particularidade de viverem associações interespecíficas muito fortes e de estarem inseridos no contexto social humano desde o seu surgimento como espécie distinta de seu ancestral (comum aos lobos). O papel da domesticação no desenvolvimento e/ou manutenção de habilidades cognitivas sociais será discutido mais à frente. 


\subsection{Fatores investigados}

Os cães avaliados foram capazes de obter informações emocionais das vocalizações e das expressões faciais e de integrá-las em um único percepto, independente da espécie, do sexo, da valência ou do lado de apresentação do estímulo. Na busca por possíveis efeitos do tipo do estímulo no desempenho dos cães no experimento de reconhecimento cross-modal de emoções, analisamos também esses quatro fatores principais e suas interações. Os achados apontam para um único efeito: o de espécie, tendo o desempenho para estímulos caninos sido significativamente maior do que o desempenho para estímulos humanos. Isto quer dizer que os sujeitos reconheceram significativamente as emoções de cães e de seres humanos, mas o fizeram de maneira mais robusta quando expostos a estímulos de cães.

Ghazanfar e Logothetis (2003) também investigaram possíveis efeitos em macacos rhesus, mas não encontraram nenhuma interação entre o tempo de olhar para a imagem congruente e o grupo de estímulos (utilizaram dois indivíduos da espécie Macaca mulatta exibindo uma expressão facial envolvida na emissão de vocalização negativa e uma expressão envolvida na emissão de vocalização positiva) ou do lado de apresentação do estímulo. No entanto, observaram um efeito de valência que será discutido mais a frente.

Taylor et al. (2011) analisaram possíveis efeitos de tamanho do modelo (pequeno ou grande), condição do playback (estímulo acústico de animal grande ou pequeno), lado do modelo congruente (esquerdo ou direito), de idade ou sexo dos sujeitos sobre as respostas dos cães ao seu procedimento de reconhecimento cross-modal, mas também não encontraram nada significativo.

No presente estudo, não foi possível investigar a existência de um efeito de idade dos sujeitos devido ao número baixo de animais testados. Quanto ao sexo, foi analisado não somente o possível efeito do sexo dos cães avaliados em relação ao desempenho, mas também a interação entre sexo do sujeito e sexo do estímulo. Mais uma vez, nada significativo foi encontrado.

É importante ressaltar, porém, que vários estudos de capacidades discriminativas e de percepção de identidade e de emoções encontraram efeitos de alguns fatores. Por esse motivo, os tópicos a seguir dedicam-se a tratar desses aspectos e a discutir os achados da presente pesquisa. 


\subsubsection{Lado (lateralidade)}

O presente estudo avaliou um possível uso diferencial dos hemisférios cerebrais no processamento de informações em uma tarefa de reconhecimento cross-modal de estímulos emocionais. No entanto, os resultados não revelaram qualquer efeito do lado de apresentação de estímulos na resposta dos sujeitos.

Os achados de Proops e McComb (2012) sobre reconhecimento cross-modal de indivíduos heteroespecíficos apontam para uma forte assimetria cortical com o uso preferencial do hemisfério esquerdo: os cavalos domésticos, sujeitos da sua pesquisa, foram significativamente melhores em associar a pessoa familiar à sua voz quando a pessoa correta estava posicionada no lado direito deles. Interessante ressaltar que nas condições em que os cavalos ouviam as vozes de seus tutores, mas não podiam vê-los, os animais mostraram uma tendência a olhar mais para o lado esquerdo, indicando um controle do hemisfério direito. Os autores sugerem que a tendência a olhar para o lado direito nas condições de teste pode ser uma característica específica no processamento cross-modal, ao invés de estar relacionada com a apresentação do estímulo visual ou auditivo em si.

Os resultados da presente pesquisa não suportam a ideia do envolvimento da lateralização cerebral no processamento cross-modal. Pelo contrário, os cães apresentaram uma resposta de reconhecimento nítido independente do lado de apresentação da expressão facial. Neste sentido, surgem algumas explicações possíveis: (i) cães e cavalos processam e integram informações de diferentes canais perceptivos de maneiras distintas; (ii) 0 processamento cross-modal se dá de formas diferentes no reconhecimento de informações de identidade e no reconhecimento de informações emocionais; (iii) uma lateralidade pode não ter sido encontrada devido ao fato dos estímulos visuais serem fotografias ao invés de estímulos reais.

O último ponto, no entanto, parece ser improvável. Se os estímulos (imagens estáticas) utilizados não possuíssem informação suficiente, uma resposta tão robusta de reconhecimento de emoções não teria sido encontrada. Além disso, muitos estudos já foram realizados com fotografias (e.g. Range et al., 2008; Racca et al., 2010; Nagasawa et al., 2011; Somppi et al., 2012). Alguns, inclusive, apresentaram evidências de lateralidade no processamento visual em cães (Guo et al., 2009; Racca et al., 2012). Outro aspecto que reforça a ideia de que as diferenças não estão baseadas na utilização de fotografias é de que Taylor et al. (2011), estudando reconhecimento cross-modal, utilizaram réplicas de cães e também não observaram sinais de lateralidade. Nesse sentido, estando o uso diferencial dos hemisférios cerebrais 
relacionado com o tipo de estímulo, é possível que os cavalos estivessem obtendo informações de outras modalidades que não a face (i.e. cheiro). Dessa forma, o processamento de outros tipos de pistas poderia estar influenciando a ativação assimétrica do córtex.

\subsubsection{Sexo}

Para esta pesquisa foram utilizados estímulos femininos e masculinos para investigar um possível efeito do sexo do estímulo no desempenho dos animais. Além disso, comparamos as respostas gerais de sujeitos machos com o de fêmeas na busca de melhor entender o papel do sexo do sujeito na capacidade de reconhecimento de emoções. Nenhum efeito significativo foi encontrado, tanto para o sexo do estímulo quanto para o sexo do sujeito.

Além do efeito de lado de apresentação do estímulo, Proops e McComb (2012) encontraram um viés de sexo na habilidade de reconhecimento cross-modal de identidade, tendo fềmeas respondido significativamente melhor do que machos. Mais uma vez, nossos resultados não corroboram esses achados. Entretanto, similarmente ao que foi discutido para lateralidade, é possível que o efeito encontrado seja fruto de diferenças metodológicas ou do tipo de investigação realizada. Para nossos cães não foi encontrada nenhuma influência do sexo dos sujeitos em suas respostas frente aos estímulos emocionais, o que pode significar que em relação à percepção de emoções machos são tão acurados quanto fềmeas.

No entanto, Taylor e colaboradores (2011), em seu estudo de reconhecimento de informações sobre tamanho corporal em cães domésticos, também não encontraram efeito de sexo do sujeito, o que reforça a ideia de possíveis diferenças fundamentais entre o presente trabalho e o estudo com os cavalos. É possível que fềmeas possuam uma habilidade mais refinada na identificação de sujeitos, mas que isso não seja verdade para tarefas de reconhecimento cross-modal de emoções ou de informações sobre o tamanho do sinalizador. Outro ponto importante é que, mais uma vez, estão envolvidas duas espécies muito diferentes - não apenas morfologicamente - e a diferença nos resultados pode estar ligada com o tipo de estrutura social encontrada em cavalos selvagens (fềmeas formam laços sociais muito próximos e a organização social é matriarcal).

Quanto aos resultados negativos para o efeito do sexo do estímulo no desempenho dos animais no presente experimento, as questões relacionadas a diferenças de experiência e expressão de emoções entre machos e fềmeas são ainda bastante controversas. Com seres humanos, uma série de estudos foi realizada e sugere-se que mulheres sejam geralmente mais 
expressivas facialmente, tanto para emoções positivas quanto para negativas, e podem ser mais sensíveis para o reconhecimento de emoções (e.g. Killgore \& Yurgelun-Todd, 2001; Hamann \& Canli, 2004; Montagne et al., 2005). De qualquer maneira, essas variações estão muito ligadas a diferenças individuais, tornando a questão da influência do sexo bastante complicada. Os mecanismos envolvidos nesses domínios e a extensão das diferenças entre homens e mulheres - quanto à expressão e percepção - ainda não são bem entendidos (Kring e Gordon, 1998). Para animais não humanos essa questão é ainda mais nebulosa.

Outro aspecto interessante foi o percebido por Nagasawa et al. (2011), que encontraram que os cinco cães testados por eles eram capazes de generalizar a habilidade de discriminar uma face sorridente de uma face neutra para faces não familiares, quando as pessoas estímulo eram do mesmo sexo do seu tutor. Argumentam que é possível que, devido à alta frequência de interações com seus tutores, os cães passem a se relacionar com seres humanos de uma maneira sexo-dependente. No entanto, não foi possível testar esse tipo de correlação para as respostas dos nossos cães, fazendo as análises em função de sexo dos tutores, devido ao tamanho de amostra pequeno.

\subsubsection{Valência}

Os resultados do presente estudo não revelaram um efeito de valência na qualidade de resposta dos cães em tarefas de integração cross-modal de emoções. Os sujeitos foram capazes de reconhecer as emoções de maneira significativa tanto para estímulos de valência positiva quanto para estímulos de valência negativa.

Ghazanfar e Logothetis (2003), em seu estudo cross-modal com macacos rhesus, observaram que os sujeitos olharam por mais tempo quando a face congruente era a correspondente à emissão do sinal sonoro positivo ("coo", de contato social), em comparação com o tempo de olhar que dedicaram para a face correspondente à vocalização negativa (articulava o chamado de ameaça), mesmo tendo sido capazes de reconhecer crossmodalmente ambas. No entanto, este resultado pode não ser reflexo de uma capacidade mais refinada de processar emoções negativas: os macacos podem ter olhado mais para a face positiva, pois simplesmente evitaram olhar para um estímulo negativo.

No presente estudo, para testar se os animais preferiram ou evitaram uma das duas valências de imagens, foi comparado o tempo dedicado às expressões faciais positivas ao tempo de olhar dos cães direcionado às expressões faciais negativas. No entanto, nada foi 
encontrado, o que significa que os cães alocaram tempos de olhar semelhantes para ambos os tipos de faces.

Existe bastante evidência empírica para uma assimetria na forma como humanos utilizam informações positivas e informações negativas para perceber o mundo. Pessoas adultas apresentam um viés negativo, ou a propensão de prestar atenção, aprender de e usar informações negativas muito mais do que positivas. Pesquisadores argumentam que esse viés teve um papel evolutivo crítico nas funções adaptativas. Sugere-se, inclusive, a existência do viés negativo desde muito cedo no desenvolvimento, no entanto, ainda não se sabe se existe influência da ontogênese sobre esse padrão (Grossmann \& Woodward, 2008). Por outro lado, não existem evidências de viés por valências positivas ou negativas em animais não humanos.

De um ponto de vista ecológico, é possível pensar que exista alguma vantagem para um refinamento do processamento de uma ou outra valência. Emoções positivas fornecem informações que vão facilitar a manutenção da coesão do grupo. Expressões faciais apaziguadoras, por exemplo, podem diminuir o nível de stress social e permitir que laços de cooperação sejam construídos a longo prazo. Por outro lado, emoções negativas contêm informações que podem ser cruciais para sobrevivência, principalmente a curto e curtíssimo prazo. Faces agressivas, por exemplo, podem representar perigo e saber se comportar apropriadamente frente a elas pode ser a chave da sobrevivência de animais em diversas situações. Dentro desse contexto, faz sentido pensar que um rápido e mais acurado reconhecimento de emoções negativas seja adaptativo e carregue mais vantagens para um indivíduo: por garantir a sobrevivência e, assim, permitir que um indivíduo reproduza, pode ter sido a característica selecionada e reforçada ao longo do processo evolutivo.

De qualquer maneira, nossos resultados não sugerem um viés por nenhuma das valências, deixando a questão da sensibilidade direcionada a emoções negativas e positivas ainda em aberto.

\subsubsection{Espécie}

O presente estudo avaliou o reconhecimento cross-modal de emoções frente a diferentes tipos de estímulos. O único efeito encontrado sobre essa habilidade foi de espécie: os sujeitos reconheceram as emoções tanto de estímulos caninos quanto de estímulos humanos, mas o fizeram de forma mais robusta para expressões emocionais de coespecíficos. 
Somppi e colaboradores (2012) observaram em cães domésticos uma preferência por imagens de outros cães e argumentaram que isto pode ser reflexo de uma expertise na percepção de faces de indivíduos da mesma espécie. De acordo com os autores, os cães devem perceber a face dos coespecíficos como mais interessantes ou informativas do que as faces humanas, devido a diferenças na relevância social e nas estratégias de comunicação entre cães e cães e entre cães e humanos. Também em 2012, Racca et al. forneceram evidências da sensibilidade de cães domésticos a expressões faciais de coespecíficos e, de forma menos robusta, a expressões faciais humanas.

Os nossos resultados parecem corroborar esses achados, uma vez que fornecem evidências nítidas de uma habilidade de reconhecimento cross-modal de emoções mais pronunciada quando os estímulos são de outros cães. É possível sugerir, então, que cães possuam padrões de exploração visual e capacidades discriminativas e de reconhecimento diferenciados: são mais sensíveis a estímulos emocionais de outros cães em comparação a expressões de pessoas ou possuem uma habilidade de reconhecimento mais refinada e conseguem obter informações emocionais de faces caninas mais facilmente.

Outro aspecto importante gira em torno da capacidade de utilização de informação emocional dos estímulos auditivos. Por exemplo, no estudo de Silwa et al. (2011) com reconhecimento cross-modal de indivíduos em primatas não humanos, alguns sujeitos foram igualmente bons na associação de informações relativas a estímulos humanos e estímulos de coespecíficos. No entanto, a fala humana possui mais informação sobre a identidade do que vocalizações de macacos, fazendo com que os humanos falantes fossem mais facilmente reconhecíveis. Nesse sentido, é possível que as similaridades nos resultados possam estar ligadas a diferenças na complexidade dos estímulos, ao invés de estarem relacionadas a outros fatores de reconhecimento.

O presente estudo, por outro lado, não investigou o reconhecimento de identidade, mas a habilidade de obtenção de informação emocional dos diferentes estímulos. Vale ressaltar também que os cães e pessoas utilizados como estímulos eram todos não familiares aos cães, ou seja, não é possível que os sujeitos houvessem criado associações prévias entre as informações de suas faces e de suas vocalizações. Além disso, o fato de se tratarem de indivíduos não familiares controla a possibilidade de os sujeitos estarem extraindo mais ou menos informações de uma ou outra espécie. Ainda, foi tomado o cuidado de serem usadas somente palavras de uma outra língua (não familiar para todos os sujeitos) para controlar qualquer tipo de experiência dos cães testados com o conteúdo linguístico das vocalizações humanas. Nesse sentido, é pouco provável que a diferença de desempenho encontrada para 
expressões emocionais de cães e expressões emocionais de seres humanos esteja relacionada com a qualidade dos estímulos, principalmente porque os resultados para estímulos caninos foram mais robustos do que para estímulos de pessoas.

\subsection{Comunicação intraespecífica e interespecífica}

Os resultados do presente estudo revelaram que cães foram capazes de perceber e extrair informações emocionais de vocalizações e expressões faciais tanto de outros cães quanto de seres humanos, no entanto, mostraram um desempenho melhor para os primeiros. Estes dados levantam a discussão de como essa habilidade por ter surgido e se estabelecido nesses animais.

É possível que a capacidade de reconhecer emoções pela face e pelas vocalizações tenha surgido com a função de possibilitar a comunicação entre cães, para que pudessem trocar informações dentro do grupo com seus coespecíficos. Mais adiante, esta habilidade pode ter sido vantajosa no estabelecimento de relacionamentos de longo prazo com seres humanos. Complementarmente, no processo de domesticação, características que facilitaram a convivência com pessoas devem ter sido selecionadas, mesmo que inconscientemente, e se fortalecido ao longo das gerações, resultando em habilidades mais refinadas tanto para interações inter como intraespecíficas. Segundo Racca et al. (2012), o processamento de expressões emocionais em cães domésticos em um contexto intraespecífico pode ter um papel crucial na coordenação de interações sociais e na facilitação da coesão do grupo.

A partir do momento em que cães passaram a constituir grupos sociais não somente com outros cães, mas também com pessoas, tiveram que criar estratégias para se comunicar tanto com coespecíficos quanto com indivíduos muito diferentes. Nesse sentido, mudanças quantitativas e qualitativas nos canais de comunicação durante a domesticação parecem ser consequências lógicas para possibilitar uma transmissão de informação eficiente entre esses animais (Feddersen-Petersen, 2000).

Diferentes mecanismos de processamento de informação emocional devem ter sido desenvolvidos em um contexto intraespecífico e um processamento acurado de emoções (e.g. expressões faciais) pode ter facilitado a formação e o estabelecimento de relações entre animais de espécies diferentes, como no caso dos seres humanos e dos cães domésticos (Racca et al., 2012). 
Segundo Zuberbühler e Byrne (2006), níveis altos de complexidade social podem ser criados em associações interespecíficas. A comunicação, portanto, não está limitada a indivíduos da mesma espécie; ela pode acontecer entre diferentes espécies, como é o caso do cão doméstico e dos humanos (Elgier et al. 2009).

A proximidade contextual e a história evolutiva compartilhada com seres humanos facilitaram o desenvolvimento de habilidades sócio-comunicativas em cães domésticos. Recentemente, por exemplo, Redigolo (2013) descobriu que cães domésticos são capazes de usar comportamentos para comunicar com seus tutores de forma funcionalmente referencial e intencional em situações que envolvem a obtenção de alimento.

A habilidade de percepção de heteroespecíficos certamente possui uma predeterminação biológica: se os indivíduos não possuem os mecanismos necessários para exercer certos comportamentos, esses comportamentos não irão existir. No entanto, a experiência com seres humanos ao longo da vida pode ser uma característica fundamental. Por exemplo, no estudo de Silwa et al. (2011) com macacos rhesus de laboratório, que possuíam interações diárias com pessoas, o reconhecimento de indivíduos de maneira crossmodal se estendeu para estímulos humanos. Os autores argumentam que esse processo não é apenas espécie-específico, mas que também se aplica para indivíduos de relevância social de outras espécies que se tornam familiares para o animal.

Dentro desta discussão, outro aspecto importante precisa ser mencionado. Macacos rhesus, assim como outros primatas não humanos, possuem uma proximidade filogenética com humanos; compartilham de configurações faciais muito semelhantes, além de serem duas espécies que fazem o uso de pistas visuais, principalmente pela face, muito frequentemente algumas expressões faciais são, inclusive, similares. Por outro lado, existe uma distância filogenética grande entre humanos e cães. No entanto, esses animais tão diferentes morfologicamente compartilham de uma história evolutiva de muitos milhares de anos, em que vários comportamentos foram desenvolvidos. Neste contexto, os processos ocorridos ao longo da domesticação parecem possuir um papel importante, podendo ter agido sobre essa habilidade em cães domésticos.

O fato de cães apresentarem reconhecimento cross-modal de emoções tanto na comunicação intraespecífica quanto na interespecífica pode significar que essa seja uma habilidade abrangente. É possível que se trate de uma adaptabilidade dos sistemas de reconhecimento, uma vez que seres humanos e cães são morfologicamente e filogeneticamente muito diferentes, mas possuem uma história social conjunta. 
A relação entre humanos e não humanos implica demandas adaptativas, que criam novas condições de seleção para a espécie que passa por um processo de domesticação (Topál et al., 2005). Já é amplamente assumido que o processo de seleção durante a domesticação deve alterar não somente os traços morfológicos de uma espécie, mas, também, seus comportamentos e seus sistemas comportamentais (i.e. Trut et al., 2004).

Alguns cientistas atribuem a propensão dos cães por interações sociais humanas à evolução convergente, em que as duas espécies geneticamente distintas foram modeladas por pressões seletivas similares (e.g. Hare \& Tomasello, 2005). É uma consequência dessa intensa cohabitação a existência em cães de habilidades cognitivas e comportamentos vistos como unicamente humanos, como o reconhecimento do estado de atenção do outro - característica já bastante evidente em cães domésticos (Redigolo, 2008; Udell \& Wynne, 2008). Segundo Reid (2009), os cães capazes de ler seres humanos, seus comportamentos, motivações, emoções e intenções tiveram uma grande vantagem sobre outros cães que não puderam responder a esses sinais.

Cães domésticos são animais muito sociais. Apresentam muitos métodos de comunicação visual como os lobos, incluindo posturas e expressões faciais que podem indicar status, agressão e outras emoções (Nagasawa et al., 2011). A habilidade de extrair informações da face de outros cães e de seres humanos e responder apropriadamente pode ter carregado vantagens seletivas durante as últimas dezenas, talvez centenas de milhares de anos, especialmente quando o conteúdo emocional dessas faces pode ser de significância comportamental adaptativa imediata para esses animais (Guo et al.., 2009). Assumimos que é possível ter sido adaptativo para os cães reconhecer as expressões emocionais, através da face e das vocalizações, humanas ao longo do processo de domesticação, uma vez que essa habilidade tenha facilitado a aproximação e estabelecimento nos agrupamentos humanos e o desenvolvimento de laços com os mesmos.

\subsection{Percepção e reconhecimento de emoções}

Nossos resultados podem ser um indicativo de que cães compreendem o conteúdo emocional nas expressões faciais e vocalizações de pessoas, neste caso, de valência positiva (alegria) e valência negativa (raiva). Os cães apresentaram uma capacidade nítida de integração de informações emocionais da voz a informações emocionais da face em seres 
humanos, o que mostra que esses animais possuem uma representação mental de vocalizações humanas. No entanto, o efeito de espécie não pode ser deixado de lado: cães apresentaram melhor desempenho nas tarefas de reconhecimento cross-modal de emoções quando frente a estímulos caninos em comparação a estímulos humanos. Isto pode sugerir que cães possuam um sistema de processamento de pistas auditivas e visuais, que foi desenvolvido em contexto intraespecífico e aproveitado (e reforçado) em contexto interespecífico.

O presente estudo traz também informações importantes sobre a expressão e a percepção de emoções entre cães domésticos. Os resultados mostram que esses animais foram capazes de extrair informações sobre o conteúdo das expressões emocionais de coespecíficos também de maneira evidente, a ponto de conseguirem integrar informações de vocalizações a informações congruentes de faces. Isto sugere que as expressões de cães continham informações relevantes para os sujeitos, que puderam discriminar expressões faciais negativas de expressões faciais positivas e vocalizações agonísticas de vocalizações de caráter afiliativo e utilizar o conteúdo das mesmas nas tarefas de reconhecimento cross-modal nas quais foram testados.

O reconhecimento de emoções pode ser entendido como uma característica funcional, que confere vantagens adaptativas àqueles que a possuem. No entanto, essa habilidade perde valor ecológico se um aspecto anterior não for atingido: o reconhecimento dos indivíduos e o armazenamento de informações de identidade na memória. Reconhecer os indivíduos de um grupo permite que um animal saiba com quem está interagindo. Mais adiante, o reconhecimento dos estados emocionais dos outros permite saber como está sendo esta interação, além de permitir a antecipação dos próximos comportamentos de um indivíduo e o planejamento de seus próprios. A percepção de emoções a longo prazo torna possível escolher, por exemplo, com quem cooperar e com quem competir e isso vai facilitar o estabelecimento e a manutenção de relacionamentos sociais. O primeiro passo, então, é ser capaz de reconhecer os outros; para saber de que indivíduos certas respostas emocionais estão vindo. Depois, torna-se muito vantajoso poder ler emoções e armazenar essas informações para uma discriminação e reconhecimento rápidos e eficientes, como no caso da percepção cross-modal. Segundo Schmidt e Cohn (2001), a capacidade de ler emoções pode ser uma ferramenta social muito importante, uma vez que pode trazer consequências positivas mútuas em termos de aptidão, tanto para o sinalizador quanto para o receptor.

Quanto aos cães e à habilidade de reconhecimento de identidade, em 2007, Adachi e colaboradores encontraram que cães domésticos são capazes de discriminar a face de seu tutor da face de uma pessoa não familiar, por meio de um paradigma de violação de expectativa. 
Em 2010, Racca et al., utilizando um paradigma de comparação visual pareada, encontraram que cães possuem a capacidade de diferenciar faces individuais baseados apenas em pistas visuais.

Partindo, então, para o reconhecimento de emoções, vários estudos já foram realizados avaliando a sensibilidade de cães domésticos a expressões emocionais, especialmente através da face e principalmente na relação com seres humanos. São resultados importantes, mas não são evidências de que os cães realmente obtêm informações sobre o conteúdo emocional dos estímulos e de que são capazes de utilizar essa informação de alguma maneira.

Recentemente, Buttelmann e Tomasello (2013) avaliaram a capacidade de cães domésticos de utilizar informações fornecidas pela face humana numa tarefa de obtenção de alimento. Encontraram que cães são capazes de distinguir e fazer uso de informações de expressões emocionais faciais humanas quando elas são bastante distintas, apresentando dificuldade em fazê-lo quando as diferenças não são muito evidentes (i.e. face feliz e face neutra). No entanto, esses pesquisadores enfrentaram uma série de dificuldades que acabaram por tirar a clareza de seus achados (e.g. desempenho individual muito baixo; viés de lado apresentado por vários animais; influência do reforço intermitente; uso de mais de uma pista relevante em cada ensaio; possível uso das pistas acústicas ao invés do uso das pistas faciais).

O estudo de Buttelmann e Tomasello é bastante importante, no entanto, além dos problemas metodológicos que enfraqueceram os resultados, o paradigma escolhido pelos autores pode levar a interpretações de baixo nível cognitivo. Os resultados podem ser reflexos de associações simples ao invés de representarem uma capacidade canina de obter informações emocionais da face e de usar essas informações. A questão crucial fica em torno do uso do alimento. Comida é um estímulo muito saliente para cães e seres humanos são os provedores desse recurso - cães familiares dependem das pessoas para receber o alimento todos os dias. Dessa maneira, cães, que são animais muito sensíveis ao comportamento humano (Udell et al., 2010), podem associar fortemente o comportamento da pessoa à obtenção do alimento e essa associação é reforçada pela alta frequência com que acontece. Sendo a alimentação um dos aspectos mais importantes para a sobrevivência, esses animais acabam por prestar bastante atenção às pistas relacionadas e é possível que ao longo da vida tenham aprendido que "nojo" representa uma comida ruim e "alegria" representa uma comida boa, além de outras associações relevantes. Nesse sentido, os resultados encontrados por Buttelmann e Tomasello podem não estar relacionados a um entendimento real do conteúdo emocional daquelas emoções. 
Nosso estudo é, então, o primeiro a trazer dados conclusivos e evidências robustas de que cães domésticos reconhecem emoções, tanto humanas quanto caninas.

\subsection{Direções futuras}

Este trabalho sobre reconhecimento de emoções em contextos intra e interespecíficos traz novas e importantes informações sobre as capacidades cognitivas de cães domésticos e sobre o processamento de informações emocionais. Além disso, demonstra a funcionalidade das expressões faciais e auditivas através das evidências de que esses animais são capazes de verdadeiramente reconhecer as emoções de coespecíficos e de heteroespecíficos. Ainda, reforçam a ideia de que cães possuam um sistema refinado de exploração das expressões emocionais de outros cães, mas que desenvolveram habilidades para também entender e se comunicar com seres humanos.

No entanto, ainda existem muitas questões importantes que precisam de atenção e que continuam sem resposta sobre o processamento das emoções em cães e os mecanismos envolvidos nesses processos. São necessárias, agora, pesquisas que avaliem outras emoções e que investiguem, por exemplo, efeitos de idade, de raças, de experiência social com outros cães e com seres humanos, para um entendimento mais robusto da habilidade de percepção e compreensão de emoções por cães.

De acordo com Dawkins (2000), a busca pela consciência em animais não humanos é frequentemente entendida como a procura por habilidades cognitivas mais complexas. É por esse motivo que a maioria das teorias da consciência da ênfase às conquistas intelectuais, como a habilidade de formar conceitos abstratos, fazer uso de linguagem e planejar e modificar seu comportamento para interagir com os outros indivíduos e com o mundo. A ciência ainda tem um longo caminho para provar a existência de uma consciência em animais não humanos, mas, acreditamos, trabalhos como este, que trazem evidências da funcionalidade da expressão e percepção de expressões emocionais, da utilização de representações mentais, de generalização de aspectos emocionais de animais tão diferentes e da formação de conceitos sobre os indivíduos e as relações sociais, possam ser um passo importante para alcançar novas perspectivas sobre animais não humanos. 
Referências 


\section{Referências}

Adachi, I., \& Fujita, K. (2007). Cross-modal representation of human caretakers in squirrel monkeys. Behavioural processes, 74, 27-32.

Adachi, I., Kuwahata, H., \& Fujita, K. (2007). Dogs recall their owner's face upon hearing the owner's voice. Animal Cognition 10, 17-21.

Ades, C., Rossi, A., \& Pinseta, D. (2000). Em Santos, C. V., Vieira, M. L. (Org). Anais do XVIII Encontro Anual de Etologia (p. 213). Florianópolis: Sociedade Brasileira de Etologia.

Artelle, K. A., Dumoulin, L. K., \& Reimchen, T. E. (2011). Behavioural responses of dogs to asymmetrical tail wagging of a robotic dog replica. Laterality, 16, 129-135.

Bekoff, M. (1974). Social play and play-soliciting by infant canids. American Zoologist, 14, 323-340.

Bekoff, M. (1977). Social communication in canids: evidence for the evolution of a stereotyped mammalian display. Science, 197, 1097-1099.

Bekoff, M. (1995). Play signals as punctuation: the structure of social play in canids. Behaviour, 132, 419-429.

Borod, J. C., Koff, E., \& Caron, H. S. (1983). Right hemispheric specialization for the expression and appreciation of emotion: A focus on the face cognitive processing in the right hemisphere. In Perecman, E. (Ed.), Cognitive processing in the right hemisphere (pp. 83110). New York: Academic Press.

Brown, D. (1990). Human universals. New York: McGraw-Hill Inc.

Bruce, V., \& Young, A. (1986). Understanding face recognition. British Journal of Psychology 77, 305-327.

Buttelmann, D., \& Tomasello, M. (2013). Can domestic dogs (Canis familiaris) use referential emotional expressions to locate hidden food? Animal Cognition, 16, 137-145.

Calvert, G. A. (2001). Crossmodal processing in the human brain: insights from functional neuroimaging studies. Cerebral Cortex 11, 1110-1123. 
Campanella, S., \& Belin, P. (2007). Integrating face and voice in person perception. Trends in Cognitive Sciences, 11, 535-543.

Custance, D., \& Mayer, J. (2012). Empathic-like responding by domestic dogs (Canis familiaris) to distress in humans: an exploratory study. Animal Cognition, 15(5), 851-859..

Davis, S. J. M., \& Valla, F. R. (1978). Evidence for domestication of the dog 12.000 years ago in the Natufian of Israel. Nature, 276, 608-610.

Darwin, C., (1872). The expression of the emotions in man and animals. London: John Murray.

Dawkins, M. S. (2000). Animal minds and animal emotions. American Zoologist, 40, 883888 .

de Haan, M., \& Nelson, C. A., (1999). Brain activity differentiates face and object processing in 6-month-old infants. Developmental Psychology, 35, 1113-1121.

de Waal, F. B. M. (2008). Putting the altruism back into altruism: the evolution of empathy. Annual Review of Psychology, 59, 279-300.

Deputte, B. L., \& Doll, A. (2011). Do dogs understand understand human facial expressions? Journal of Veterinary Behavior, 6, 78-79.

Ekman, P., (1972). Universals and cultural differences in facial expressions of emotion. Nebraska Symposium on Motivation. Lincoln, NE: University of Nebraska Press.

Elgier, A. M., Jakovcevic, A., Barrera, G., Mustaca, A. E., \& Bentosela, M. (2009). Communication between domestic dogs (Canis familiaris) and humans: dogs are good learners. Behavioural Processes 81, 402-408.

Ehrlichman, H. (1986). Hemispheric asymmetry and positive-negative affect. In Ottoson, D. (Ed.) Duality and unity of the brain: Unified functioning and specialization of the hemispheres (pp. 194-206). London: Macmillan.

Faragó, T., Pongrácz, P., Miklósi, A., Huber, L., Virányi, Z., \& Range, F. (2010a). Dogs' expectation about signalers' body size by virtue of their growls. Plos One, 5(12), doi:10.1371/journal.pone.0015175. 
Faragó, T., Pongrácz, P., Range, F., Virányi, Z., \& Miklósi, A. (2010b). 'The bone is mine': affective and referential aspects of dog growls. Animal Behaviour, 79, 917-925.

Feddersen-Petersen, D. U. (2000). Vocalization of European wolves (Canis lupus lupus L.) and various dog breeds (Canis lupus f. fam.). Archives Animal Breeding, 43, 387-397.

Feddersen-Petersen, D. U. (2001). Biology of aggression in dogs. ,Dtsch. Tierarztl. Wochenschr, 108, 94-101.

Feddersen-Petersen, D. U. (2005). Communicationn in wolves and dogs. In. Encyclopedia of animal behavior, vol. I: Greenwood Publishing Group (pp. 385-394).

Fox, M. W. (1970). A comparative study of the development of facial expressions in canids: Wolf, Coyote and Foxes. Behaviour, 36, 49-73.

Fridlund, A. J. (1997). The new ethology of human facial expressions. In Russel, J. A., \& Fernández-Dols, J. M. (Eds.) The Psychology of facial expression. (pp. 103-129) New York: Cambridge University Press.

Fukuzawa, M. Mills, D. S., \& Cooper, J. J. (2005). The effect of human command phonetic characteristics on auditory cognition in dogs (Canis familiaris). Journal of Comparative Psychology, 119, 117-120.

Gácsi, M., Miklósi, Á., Varga, O., Topál, J., \& Csányi, V. (2004). Are readers of our face or readers of our minds? Dogs (Canis familiaris) show situation dependent recognition of human's attention. Animal Cognition 7(3), 144-153.

Galibert, F., Quignon, P., Hitte, C., \& André, C. (2011). Toward understanding dog evolutionary and domestication history. Comptes Renduus Biologies, 334, 190-196.

Ghazanfar, A. A., \& Logothetis, N. K. (2003). Facial expressions linked to monkey calls. Nature, 423, 937-938.

Gerhardt, H. C. (1992). Multiple messages in acoustic signals. Seminars in Neuroscience, 4, 391-400. 
Gothard, K. M., Erickson, C., A., \& Amaral, D. G. (2003). How do rhesus monkeys (Macaca mulatta) scan faces in a visual paired comparison task? Animal Cognition, 7, 25-36.

Guo, K., Meints, K., Hall, C., Hall, S., \& Mills, D. (2009). Left gaze bias in humans, rhesus monkeys and domestic dogs. Animal Cognition 12, 409-418.

Guo, K., Smith, C., Powell, K., \& Nicholls, K. (2012). Consistent left gaze bias in processing different facial cues. Psychological Research, 76, 263-269.

Guo, K., Tunnicliffe, D., \& Roebuck, H., (2010). Human spontaneous gaze patterns in viewing of faces of different species. Perception, 39, 533-542.

Hamann, S., \& Canli, T. Individual differences in emotion processing. (2004). Current opinion in neurobiology, 14, 233-238.

Hare, B., \& Tomasello, M. (2005). Human-like social skills in dogs? Trends in Cognitive Science, 9, 405-454.

Hare, B., Williamson, C., \& Tomasello, M., (2002). The domestication of social cognition of dogs. Science, 298, 1634-1636.

Hare, B., Wobber, V., \& Wrangham, R. (2012). The self-domestication hypothesis: evolution of bonobo psychology. Animal Behaviour, 83, 573-585.

Henderson, J. M. (2003). Human gaze control during real-world scene perception. Trends in Cognitive Science, 7, 498-504.

Horowitz, A. (2009). Attention to attention in domestic dog (Canis familiaris) dyadic play. Animal Cognition, 12, 107-108.

Humphrey, N. B. (1976). The social function of intellect. In Bateson, P. P. G., \& Hinde, R. A. (Eds.) Growing points in ethology. (pp. 303-317) Cambridge, Cambridge University Press.

Izard, C, E. (2009). Emotion theory and research: highlights, unanswered questions, and emerging issues. Annual Review of Psychology, 60, 1-25.

Izumi, A., \& Kojima, S. (2004). Matching vocalizations to vocalizing faces in a chimpanzee (Pan troglodytes). Animal Cognition, 7, 179-184. 
Killgore, W. D. S. \& Yurgelun-Todd, D, A. (2001). Sex differences in amygdala activation during the perception of facial affect. Motivation, emotion, feeding, drinking, 12, 2543-2547.

Kring, A. M. \& Gordon, A. H. (1998). Sex differences in emotion: expression, experience, and pshysiology. Journal of personality and social psychology, 74, 686-703.

Kojima, S., Izumi, A., \& Ceugniet, M. (2003). Identification of vocalizers by pant hoots, pant grunts and screams in a chimpanzee. Primates, 44, 225-230.

Kondo, N., Izawa, E., \& Watanabe, S. (2012). Crows cross-modally recognize group member but not non-group members. Proceedings of The Royal Society, doi: 10.1098/rspb.2011.2419.

Lampe, J. F., \& Andre, J. (2012). Cross-modal recognition of human individuals in domestic horses (Equus caballus). Animal Cognition, 15, 623-630.

Martinez, L., \& Matsuzawa, T. (2009). Auditory-visual intermodal matching based on individual recognition in a chimpanzee (Pan troglodytes). Animal Cognition, 12, 71-85.

Miklósi, Á., Kubínyi, E., Topál, J., Gácsi, M., Virányi, Z., \& Csányi, V. (2003). A simple reason for a big difference: wolves do not look back at humans but dogs do. Current Biology $13,763-766$.

Miklósi, Á., Topál, J., \& Csányi, V. (2004). Comparative social cognition: what can dogs teach us. Animal Behavior, 67, 995-1004.

Miklósi, Á., (2007). Dog behaviour, evolution and cognition. Oxford University press.

Molnár, C., Pongrácz, P., Faragó, T., Dóka, A., \& Miklósi, A. (2009). Dogs discriminate between barks: The effect of context and identity of the caller. Behavioural Processes, 82, 198-201.

Montagne, B., Kessels, R. P. C., Frigerio, E., de Haan, E. H. F., \& Perrett, D. I. (2005). Sex differences in the perception of affective facial expressions: do men really lack emotional sensitivity? Cognitive Processing, 6, 136-141.

Morisaki, A., Takaoka, A., \& Fujita, K. (2009). Are dogs sensitive to the emotional state of humans? Journal of Veterinary Behavior, 4, 49. 
Nagasawa, M., Murai, K., Mogi, K., \& Kikusui, T., (2011). Dogs can discriminate human smiling faces from blank expressions. Animal Cognition, 14, 525-533.

Parr, L. A. (2004). Perceptual biases for multimodal cues in chimpanzee (Pan troglodytes) affect recognition. Animal Cognition, 7, 171-178.

Parr, L. A., Winslow, J. T., Hopkins, W. D., \& de Waal, F. B. M. (2000). Recognizing facial cues: individual discrimination by Chimpanzees (Pan troglodytes) and Rhesus Monkeys (Macaca mulatta). Journal of Comparative Psychology, 114, 47-60.

Pascalis, O., de Haan, M., \& Nelson, C. A. (2002). Is face processing species-specific during the first year of life? Science, 296, 1321-1322.

Pongrácz, P., Miklósi, A., \& Csányi, V. (2001). Owner's beliefs on the ability of their pet dogs to understand human verbal communication: a case of social understanding. Current Psychology of Cognition, 20, 87-107.

Pongrácz, P., Molnár, C., \& Miklósi, A. (2006). Acoustic parameters of dog barks carry emotional information for humans. Applied Animal Behaviours Science, 100, 228-240.

Pongrácz, P., Molnár, C., \& Miklósi, A. (2010). Barking in family dogs: An ethological approach. The Veterinary Journal, 183, 141-147.

Proops, L. \& McComb, K. (2012). Cross-modal individual recognition in domestic horses (Equus caballus) extends to familiar humans. Proceedings of The Royal Society, 279, 31313138 .

Proops, L., McComb, K., \& Reby, D. (2009). Cross-modal individual recognition in domestic horses (Equus caballus). PNAS, 106, 947-951.

Quaranta, A., Siniscalchi, M., \& Vallortigara, G. (2007). Asymmetric tail-wagging responses by dogs to different emotive stimuli. Current Biology, 17, 199-201.

Racca, A., Guo, K., Meints, K., \& Mills, D. S. (2012). Reading faces: differential lateral gaze bias in processing canine and human facial expressions in dogs and 4-year-old children. Plos One, 7(4), doi:10.1371/journal.pone.0036076. 
Racca, A., Amadei, E., Ligout, S., Guo, K., Meints, K., \& Mills, D. (2010). Discrimination of human and $\operatorname{dog}$ faces and inversion responses in domestic dogs (Canis familiaris). Animal Cognition, 13, 525-533.

Range, F., Aust, U., Steurer, M., \& Huber, L. (2008). Visual categorization of natural stimuli by domestic dogs. Animal Cognition, 11, 339-347.

Redigolo, C. S. (2008). O papel da atenção humana na comunicação cão-ser humano por meio de um teclado. São Paulo, Universidade de São Paulo. Dissertação de Mestrado (89 p).

Redigolo, C. S. (2013). Functionally referential and intentional communication in dogs (Canis familiaris). São Paulo, Universidade de São Paulo. Tese de Doutorado (142 p).

Reid, P. J. (2009). Adapting to the human world: dogs' responsiveness to our social cues. Behavioural Processes, 80, 325-333.

Ribeiro, F. L., Bussab, V. S. R., \& Otta, E. (2009). Nem alfa, nem ômega: anarquia na savana In Otta, E., \& Yamamoto, M. E. (Coords.). Psicologia evolucionista. (pp 176-187) Rio de Janeiro: Guanabara Koogan.

Ruffman, T., \& Morris-Trainor, Z. (2011). Do dogs understand human emotional expressions? Journal of Veterinary Behavior, 6, 97-98.

Savalli, C., \& Ades, C. (2011). Diálogos entre cães e pessoas: uma comunicação especial. Anais do XXIX Encontro Anual de Etologia. Uberlândia: Sociedade Brasileira de Etologia.

Savalli, C., Brandão, M. M., Domingues, T., Honório, M. A., \& Ades, C. (2009). Dog-human communication through a keyboard: is human attentional state relevant? Journal of Veterinary Behavior, 4(2), 55.

Savolainen, P., Zhang, Y., Luo, J., Lundeberg, J., \& Leitner, T. (2002). Genetic evidence for an East Asian origin of domestic dogs. Science, 298, 1610-1613.

Schmidt, K. L., \& Cohn, J. F. (2001). Human facial expressions as adaptations: evolutionary questions in facial expression research. Yearbook of Physical Anthropology, 44, 3-24.

Schwab, C., \& Huber, L. (2006). Obey or not obey? Dogs (Canis familiaris) behave differently in response to attentional states of their owners. Journal of Comparative Psychology, 120, 169-175. 
Silwa, J., Duhamela, J., Pascalis, O., \& Wirtha, S. (2011). Spontaneous voice-face identity matching by rhesus monkeys for familiar conspecifics and humans. PNAS, 108, 1735-1740.

Siniscalchi, M., McFarlane, J. R., Kauter, K. G., Quaranta, A., \& Rogers, L. J. (2013). Cortisol levels in hair reflect behavioural reactivity of dogs to acoustic stimuli. Research in Veterinary Science, 93, 49-54.

Siniscalchi, M., Quaranta, A., \& Rogers, L. J. (2008). Hemispheric Specialization in Dogs for Processing Different Acoustic Stimuli. PlosOne, 3, doi:10.1371/journal.pone.0003349.

Siniscalchi, M., Sasso, R., Pepe, A. M., Dimatteo, S., Vallortigara, G., \& Quaranta, A. (2011). Sniffing with the right nostril: lateralization of response to odour stimuli by dogs. Animal Behaviour, 82, 399-404.

Siniscalchi, M., Sasso, R., Pepe, A. M., Vallortigara, G., \& Quaranta, A. (2010). Dogs turn left to emotional stimuli. Behavioural Brain Research, 208, 516-521.

Somppi, S., Törnqvist, H., Hänninen, L., Krause, C., \& Vainio, O. (2012). Dogs do look at images: eye tracking in canine cognition research. Animal Cognition, 15, 163-174.

Taylor, A. M., Reby, D., \& McComb, K. (2011). Cross modal perception of body size in domestic dogs (Canis familiaris). Plos One, 6(2), doi:10.1371/journal.pone.0017069.

Topál, J., Gácsi, M., Miklósi, A., Virányi, Z., Kubinui, E., \& Csányi, V. (2005). Attachment to humans: a comparative study on hand-reared wolves and differently socialized dog puppies. Animal Behaviour, 70, 1367-1375.

Topál. J. Byrne, R., Miklósi, Á., \& Csányi, V. (2006). Reproducing human actions and action sequences: "Do as I Do!" in a dog. Animal Cognition, 9, 355-367.

Trut, L. N., Plyusnina, I. Z., \& Oskina, I. N. (2004). An experiment on fox domestication and debatable issues of evolution of the dog. Russian Journal of Genetics, 40, 644-655.

Udell, M. A. R., Dorey, N. R., \& Wynne, C. D. L. (2010). What did domestication do to dogs? A new account of dogs' sensitivity to human actions. Biological Reviews, 85, 327-345. 
Udell, M. A. R., \& Wynne, C. D. L., (2008). A review of domestic dogs' (Canis familiaris) human-like behaviors: or why behavior analysts should stop worrying and love their dogs. Journal of the Experimental Analysis of Behavior, 89, 247-261.

Vais, A., Grossmann, T., \& Woodward, A. (2008). Not all emotions are created equal: the negativity bias in social-emotional development. Psychological Bulletin, 134, 383-403.

Vilà, C., Savolainen, P, Maldonado, J. E., Rice, I. R., Honeycutt, J. E., Crandall, R. L., Lundeberg, K. A., \& Wayne, R. K. (1997). Multiple and ancient origins of the domestic dog. Science, 276, 1687-1689.

Virányi, Z., Topál, J., Gácsi, M., Miklósi, Á., \& Csányi, V. (2004). Dogs respond appropriately to cues of humans' attentional focus. Behavioural Processes, 66, 161-172.

Williams, F. J., Mills, D., \& Guo, K. (2011). Development of a head-mounted, eye-tracking system for dogs. Journal of Neuroscience Methods, 194, 259-265

Yeon, S. C. (2007). The vocal communication of canines. Journal of Veterinary Behavior, 2, 141-144.

Yin, S., \& McCowan, B. (2004). Barking in domestic dogs: context specificity and individual identification. Animal Behaviour, 68, 343-355.

Yuval-Greenberg, S., \& Deouell, L. Y. (2009). The dog's meow: asymmetrical interaction in cross-modal ibject recognition. Experimental Brain Research, 193, 603-614.

Zuberbühler, K., \& Byrne, R. W. (2006). Social cognition. Current Biology, 16, 18. 
Anexos 
Anexo A

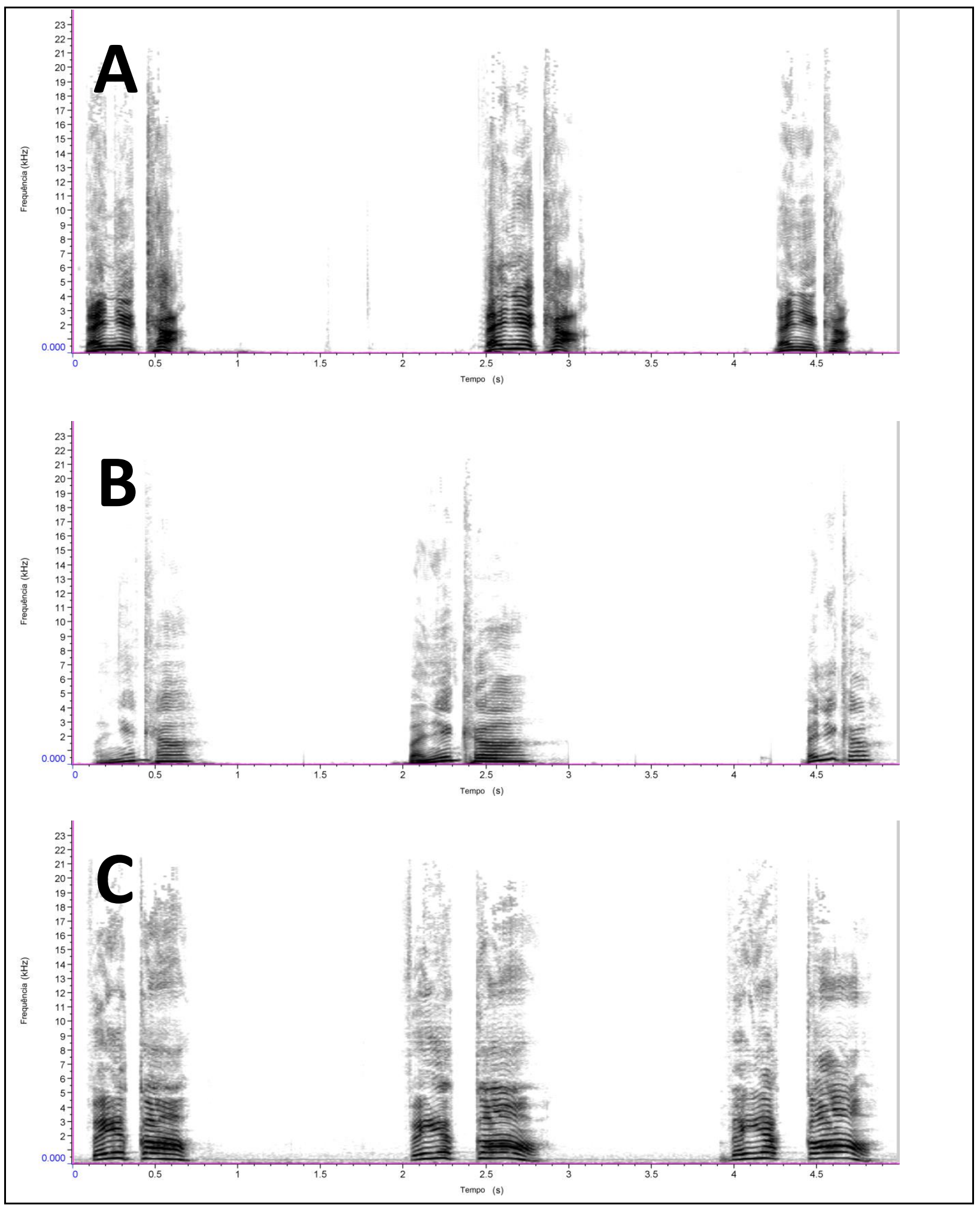




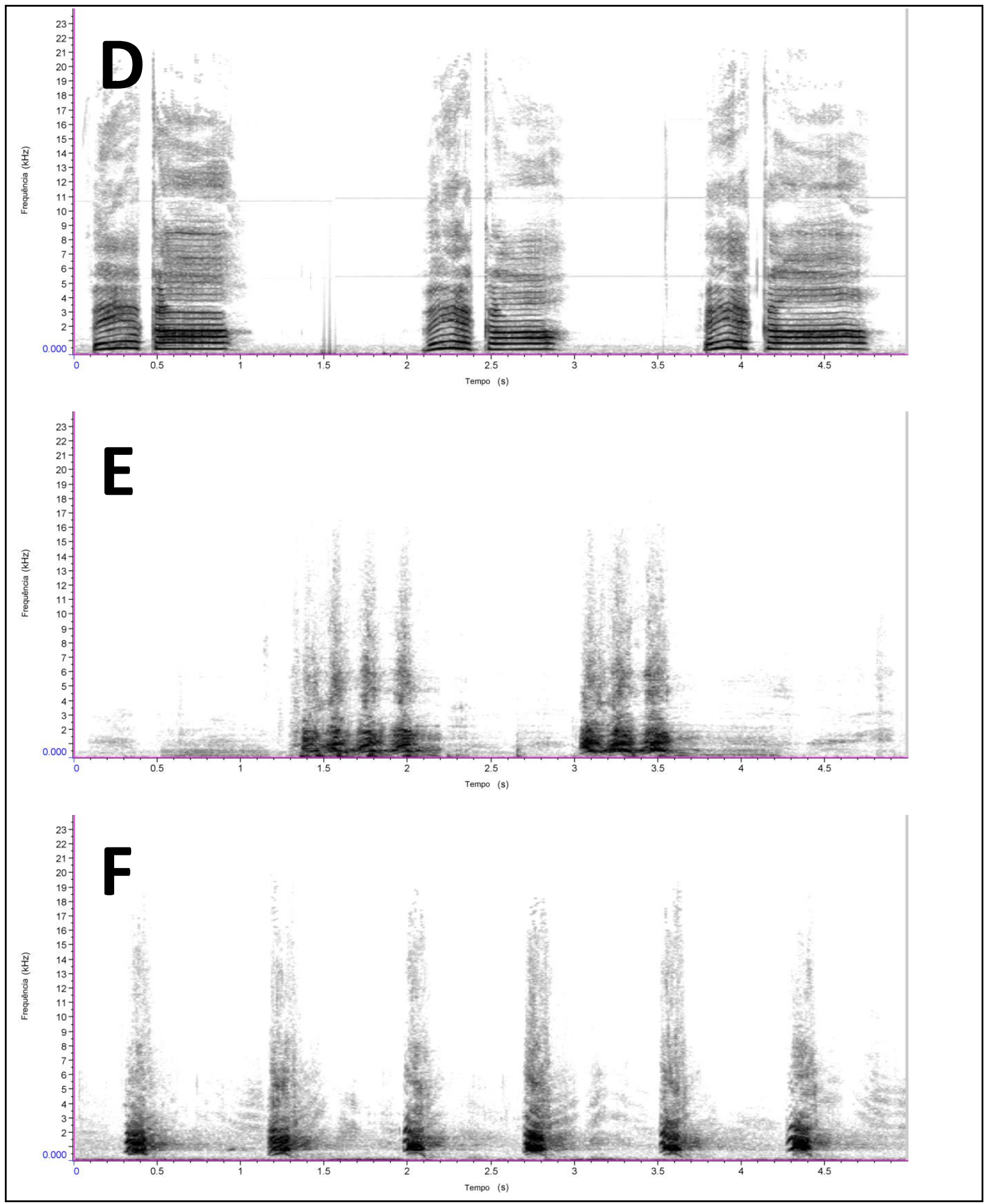




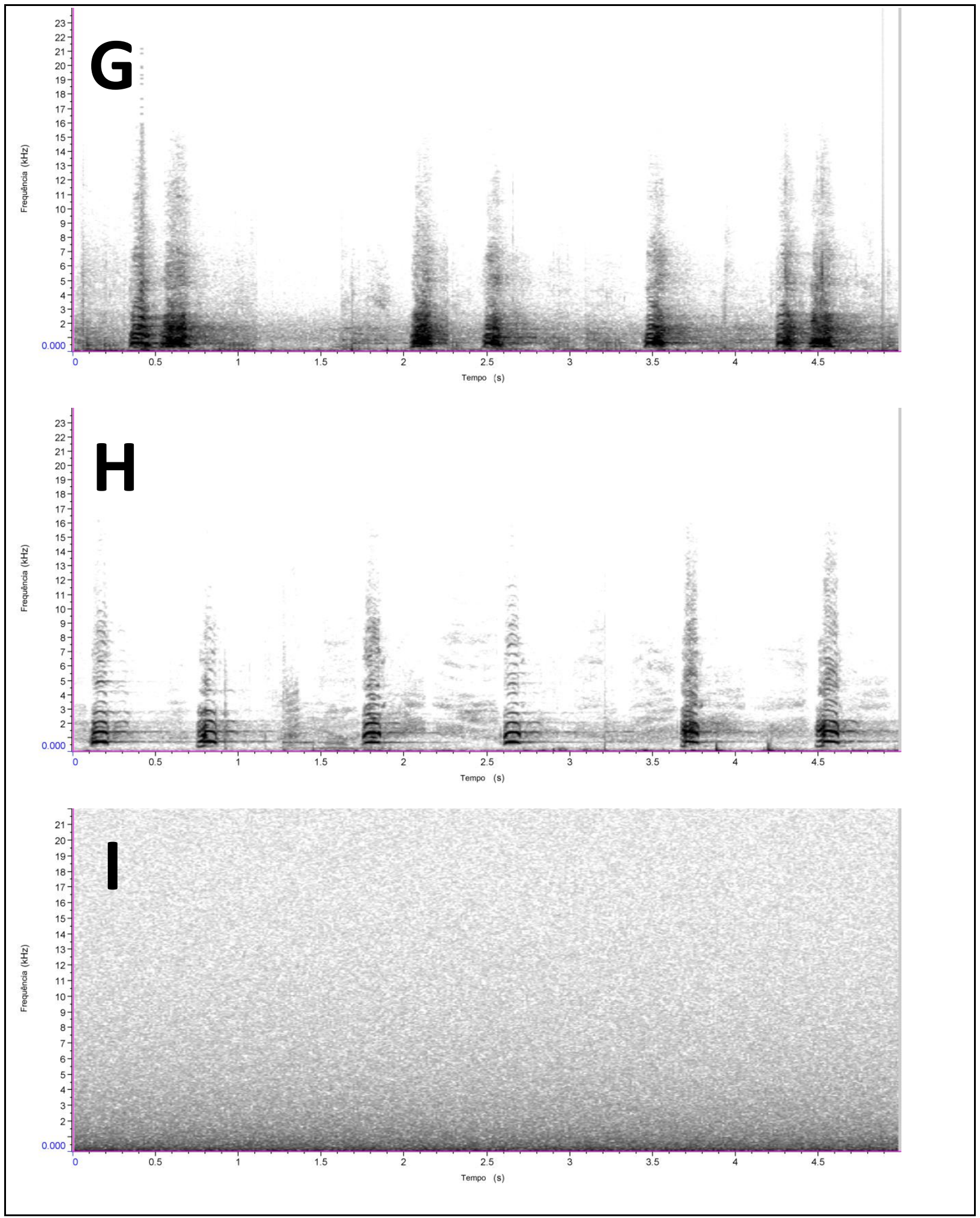

Figura 15. Estímulos acústicos. A) Raiva - homem B) Feliz - homem; C) Raiva - mulher; D) Feliz - mulher; E) Latido agressivo - fêmea; F) Latido de brincadeira - fêmea; G) Latido agressivo - macho; H) Latido de brincandeira - macho; I) Som neutro. 


\section{Anexo B}

Tabela 5. Possíveis combinações para estímulos caninos.

\begin{tabular}{|cccc|}
\hline Ensaio & Tela 1 (direita do cão) & Tela 2 (esquerda do cão) & Som \\
\hline 1 & Face Raiva - macho & Face Feliz - macho & F - macho \\
\hline 2 & Face Feliz - macho & Face Raiva - macho & F - macho \\
\hline 3 & Face Raiva - macho & Face Feliz - macho & R - macho \\
\hline 4 & Face Feliz - macho & Face Raiva - macho & R - macho \\
\hline $5 *$ & Face Feliz/Face Raiva - macho & Face Raiva/Face Feliz - macho & SN \\
\hline 6 & Face Raiva - fềmea & Face Feliz - fêmea & F - fêmea \\
\hline 7 & Face Feliz - fềmea & Face Raiva - fêmea & F - fêmea \\
\hline 8 & Face Raiva - fềmea & Face Feliz - fêmea & R - fêmea \\
\hline 9 & Face Feliz - fềmea & Face Raiva - fêmea & R - fêmea \\
\hline $10 *$ & Face Feliz/Face Raiva - fềmea & Face Raiva/Face Feliz - fêmea & SN \\
\hline
\end{tabular}

*controles

Tabela 6. Possíveis combinações para estímulos humanos.

\begin{tabular}{|cccc|}
\hline Ensaio & Tela 1 (direita do cão) & Tela 2 (esquerda do cão) & Som \\
\hline 1 & Face Agressiva - macho & Face Feliz - macho & F - macho \\
\hline 2 & Face Brincadeira - macho & Face Raiva - macho & F - macho \\
\hline 3 & Face Agressiva - macho & Face Feliz - macho & R - macho \\
\hline 4 & Face Brincadeira - macho & Face Raiva - macho & R - macho \\
\hline $5 *$ & $\begin{array}{c}\text { Face Brincadeira/Face Agressiva } \\
\text { macho }\end{array}$ & Face Agressiva/Face Brincadeira - & SN \\
\hline 6 & Face Agressiva - fềmea & Face Feliz - fêmea & F - fêmea \\
\hline 7 & Face Brincadeira - fềmea & Face Raiva - fêmea & F - fêmea \\
\hline 8 & Face Agressiva - fềmea & Face Feliz - fềmea & R - fềmea \\
\hline 9 & Face Brincadeira - fềmea & Face Raiva - fêmea & R - fềmea \\
\hline $10 *$ & $\begin{array}{c}\text { Face Brincadeira/Face Agressiva - } \\
\text { fềmea }\end{array}$ & $\begin{array}{c}\text { Face Agressiva/Face Brincadeira } \\
- \text { fềmea }\end{array}$ & SN \\
\hline
\end{tabular}

*controles 